UNIVERSIDADE DE SÃO PAULO

FACULDADE DE FILOSOFIA, LETRAS E CIÊNCIAS HUMANAS DEPARTAMENTO DE TEORIA LITERÁRIA E LITERATURA COMPARADA

MAURÍCIO REIMBERG

\title{
A crítica de Roberto Schwarz (1958-1968): um percurso atravessado pelo golpe de 1964
}

VERSÃO CORRIGIDA

SÃO PAULO

2019 
UNIVERSIDADE DE SÃO PAULO

FACULDADE DE FILOSOFIA, LETRAS E CIÊNCIAS HUMANAS

DEPARTAMENTO DE TEORIA LITERÁRIA E LITERATURA COMPARADA

\section{A crítica de Roberto Schwarz (1958-1968): um percurso atravessado pelo golpe de 1964}

Maurício Reimberg

Tese apresentada ao Programa de PósGraduação do Departamento de Teoria Literária e Literatura Comparada da Faculdade de Filosofia, Letras e Ciências Humanas da Universidade de São Paulo, para a obtenção do título de Doutor em Letras.

Orientador: Prof. Dr. Edu Teruki Otsuka

Versão corrigida

SÃO PAULO

2019 
Autorizo a reprodução e divulgação total ou parcial deste trabalho, por qualquer meio convencional ou eletrônico, para fins de estudo e pesquisa, desde que citada a fonte.

Catalogação na Publicação

Serviço de Biblioteca e Documentação

Faculdade de Filosofia, Letras e Ciências Humanas da Universidade de São Paulo

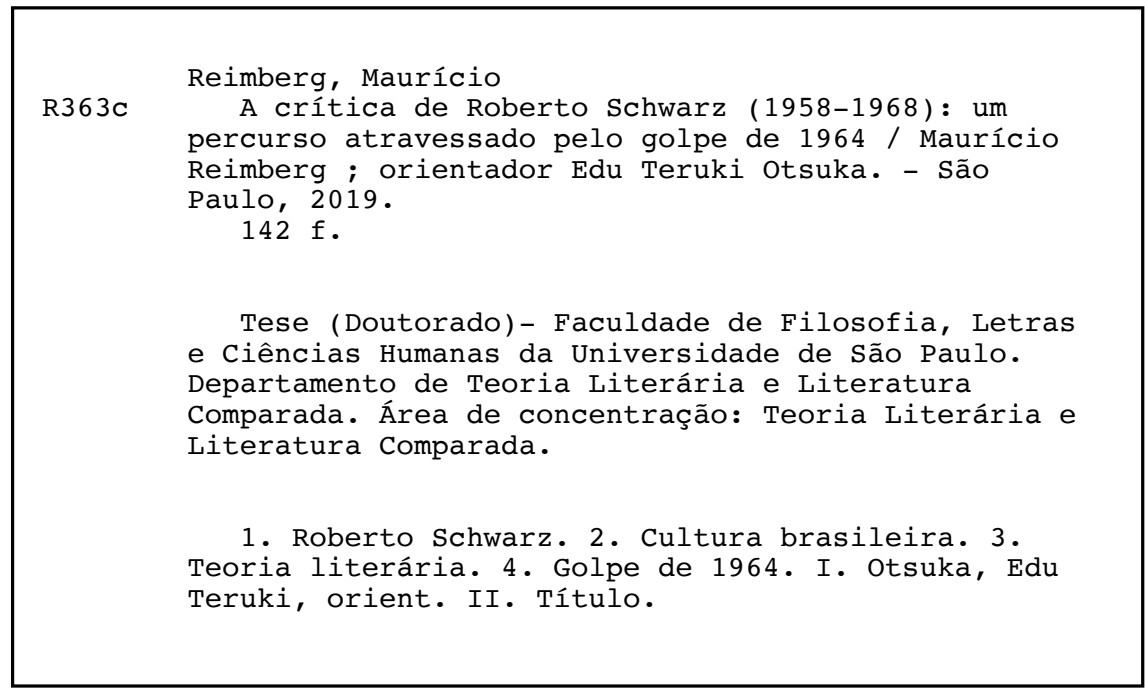




\section{Termo de Ciência e Concordância do orientador}

Nome do aluno: Maurício Reimberg dos Santos

Data da defesa: 17/05/2019

Nome do Prof. orientador: Edu Teruki Otsuka

Nos termos da legislação vigente, declaro ESTAR CIENTE do conteúdo deste EXEMPLAR CORRIGIDO elaborado em atenção às sugestões dos membros da comissão Julgadora na sessão de defesa do trabalho, manifestando-me plenamente favorável ao seu encaminhamento e publicação no Portal Digital de Teses da USP.

São Paulo, 12 de julho de 2019.

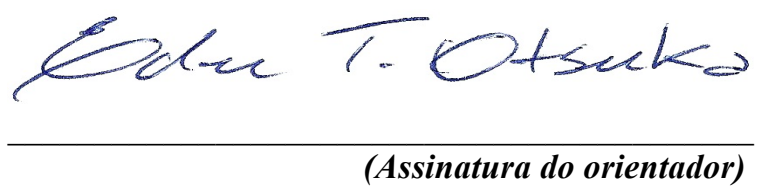


O aspecto decisivo da atividade crítica é o de saber se ela se fundamenta numa análise objetiva, num plano estratégico que contenha em si mesmo uma lógica e uma honestidade próprias. (...) É isso que quase sempre falta hoje em dia, porque a estratégia política só nos casos mais destacados corresponde a uma estratégia crítica; apesar disso, é esse o objetivo que se deve ter em vista.

Walter Benjamin, Programa da crítica literária (1929-1930)

Meu país bicho-de-concha para dentro de sua casca sem contorno

Zulmira Ribeiro Tavares, Um estado muito interessante 


\section{RESUMO}

Esta tese investiga aspectos da configuração do raciocínio crítico de Roberto Schwarz. O principal material de análise são os ensaios sobre formas estéticas e culturais brasileiras redigidos pelo autor entre 1958 e 1968, num período que abrange a sua produção teórica anterior ao exílio na França. No exame deste percurso, pretende-se distinguir os embates contraditórios entre as categorias do crítico e certa experiência histórica ambivalente internalizada pelo romance local, que seria um dado estruturante na reflexão de Schwarz. Num primeiro momento, enquanto essa matéria social já desponta sob o signo difuso do malogro do realismo literário no país, o ponto de vista analítico-interpretativo supõe uma referência comum à noção de obra autônoma como instância congenial à crítica dialética. Às voltas com o golpe empresarial-miliar de 1964, Schwarz buscaria operar de modo incisivo com a sua imediatidade prática. E esse anseio de eficácia política da crítica, ao esbarrar em limites históricos, redefine e acirra os vetores divergentes que vinham caracterizando a sua experiência social do tempo. Desse modo, entrechocam-se ali juízos orientados por uma temporalidade cumulativa e ascendente, disputada em termos políticos radicais - e apoiada na crítica à ordem "populista" derrotada -, e diagnósticos sobre uma situação presente que parecia se acomodar a si mesma, sem antagonismos de classe nitidamente configurados, redimensionando-se o que Schwarz entendia ser o "desdobramento realista da vida".

Palavras-chave:

Roberto Schwarz; Forma literária; Sociedade brasileira; Golpe de 1964. 


\begin{abstract}
This dissertation investigates aspects of the configuration of Roberto Schwarz's critical argument. The main material of analysis are the essays about aesthetical and Brazilian cultural forms written by the author between 1958 and 1968, in a period that embraces his theoretical production prior to his exile in France. In the survey of this path, it is intended to distinguish the contradictory clashes between the categories of the critic and certain ambivalent historical experience internalized by the local novel, which would be a structuralizing data of Schwarz's meditation. At a first moment, while this social matter already appears under the diffuse sign of failure of literary realism in the country, the analytical-interpretive point of view supposes a common reference to the notion of autonomous work as the congenial instance to the dialectical criticism. Dealing with the corporate-military 1964 Brazilian coup d'état, Schwarz would operate in a more incisive way with its practical immediacy. And this wish of the political efficacy of the criticism, when bumped against historical limits, redefines and stirs the divergent vectors that used to characterize his social experience of time. In this way, judgments oriented by a cumulative and ascending temporality, disputed in radical political terms - and backed by the criticism to the defeated "populist" order -, clash against diagnoses about a present situation that seemed to accommodate in itself, with no class antagonisms clearly configured, resizing what Schwarz understood to be the "realistic unfolding of life".
\end{abstract}

Keywords:

Roberto Schwarz; Literary form; Brazilian society; 1964 Brazilian coup d'état. 


\section{SUMÁRIO}

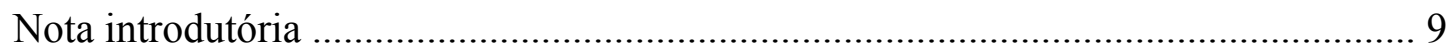

\section{Capítulo I: Um jovem materialista e o tempo sem História}

1. De costas para o tempo do mundo .................................................................... 12

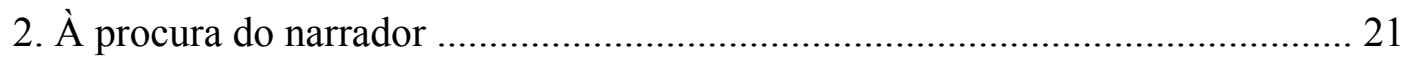

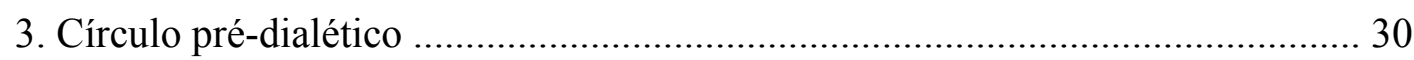

4. Tempo progressista e ruínas alegóricas ......................................................... 35

\section{Capítulo II: Vozes da imediatidade prática no Brasil pré-1964}

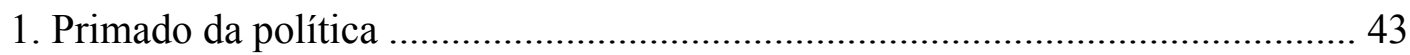

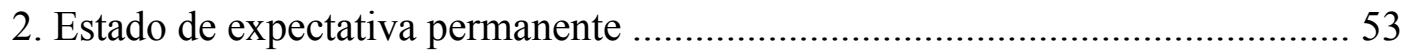

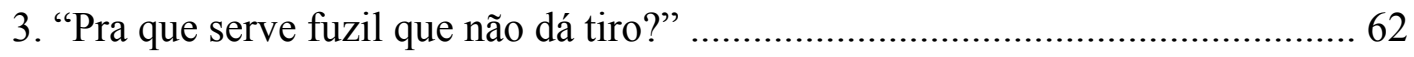

\section{Capítulo III: Desejo de intervenção e cultura confinada}

1. O amanuense Belmiro: uma imagem de Brasil ............................................. 76

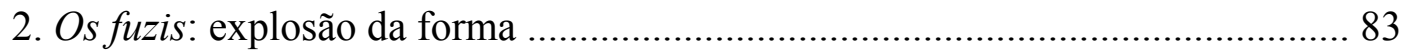

3. Entre mercadorias e símbolos da revolução ..................................................... 92

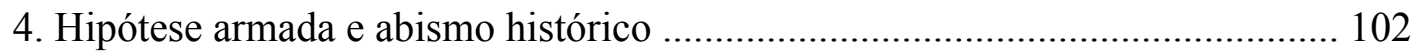

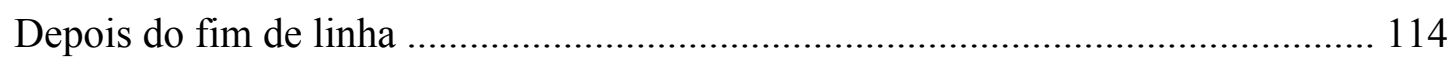

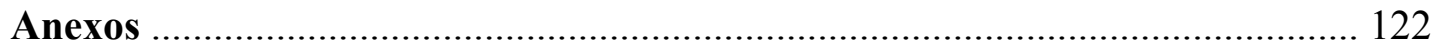

Tempo de ficar velho (1959), de Roberto Schwarz ................................................ 122

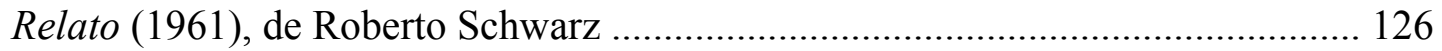

Textos do autor por ordem cronológica (1958-1972) ......................................... 130

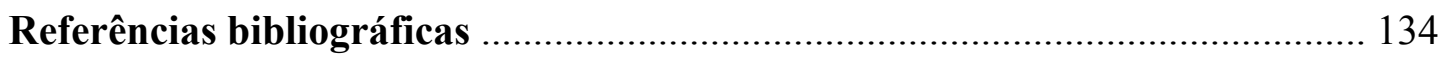




\section{Nota introdutória}

Esta tese examina a crítica de juventude de Roberto Schwarz, dedicando-se principalmente aos seus ensaios voltados a formas estéticas e culturais brasileiras. A periodização adotada aqui inicia-se em 1958 - quando Schwarz publica o seu primeiro artigo crítico no Suplemento Literário d'O Estado de S. Paulo - e segue o percurso intelectual do autor até o momento anterior ao exílio na França, que ocorre no começo de 1969, após a decretação do Ato Institucional n 5 (AI-5) pela ditadura.

No primeiro capítulo, que trata dos seus textos pré-1964, busca-se aferir - em linhas gerais - os inícios de uma trama teórico-conceitual em corpo a corpo objetivo com uma matéria histórica não reconhecida, mas que interpela indiretamente o autor. Schwarz se vê às voltas com formas literárias sacolejadas por contrastes rebarbativos, em que as experiências narradas apresentam conexões tênues entre si, estilhaçando-se a todo momento, e o passado não se assenta numa distância objetiva. O seu juízo mais recorrente sobre essa experiência brasileira, tal como configurada nos objetos por ele analisados - os romances de Guimarães Rosa, Clarice Lispector, Cyro dos Anjos, entre outros -, vincula-se à percepção de uma temporalidade social alheia e mesmo incompatível com a "História". Entre 1958 e 1961, o modo como Schwarz explica essa dita rarefação histórica nas obras nacionais oscila de maneira mais significativa. Ele identifica excessos de "reflexão", insuficiência narrativa, psicologismo, passadismo literário, eloquência retórica, irracionalismo, etc.

Nesses ensaios, a referência ao romance realista europeu, uma das matrizes da crítica schwarziana, não funda propriamente um termo de comparação estável, dada a dificuldade objetiva na construção de mediações históricas para o exame da matéria social nas narrativas brasileiras. No entanto, esses primeiros trabalhos já são atravessados pela presença ambivalente de uma temporalidade social diversa, que não indicia integração progressiva dos contrários, acumulação reparadora ou desenvolvimento ascendente, o que tensiona as categorias do crítico. Na medida em que se busca mapear os entraves internos às obras brasileiras que impediriam a sua autonomia significativa no plano simbólico, destaca-se - cada vez mais - a presença fundamental da ideia de tempo nos juízos literários do crítico, aspecto que serve como fio condutor desta tese. De fato, a concepção que Schwarz erige a respeito das 
possibilidades do realismo literário no país não se configura como algo trivial. Como se verificará adiante, o que o autor define como "desdobramento realista da vida" tem consequências políticas importantes, prefigurando em parte a sua crítica ao “populismo" e a adesão à luta armada (quando a percepção histórica sobre a guerrilha também modificava-se, em particular, pela experiência da Revolução Cubana).

É nesse sentido que o segundo capítulo da tese acompanha o retorno de Schwarz ao Brasil, após uma temporada acadêmica nos Estados Unidos (1961-1963). Apresenta-se, então, um breve panorama histórico sobre o momento pré-golpe de acirramento da luta popular, considerando o modo por meio do qual o crítico elabora essa nova conjuntura. Após 1964, quando são suprimidas à força o que Schwarz chamaria de "transfusões da experiência social" - dissociando-se as camadas subalternas e a intelectualidade -, o autor tenta operar de modo incisivo com a sua imediatidade prática. Nesse passo, o regime unificado e autorreferido da obra artística, a partir do qual se sublinhava a não realização do realismo sério e problematizante na literatura brasileira, desloca-se e perde - de modo parcial e temporário - o estatuto de ideia reguladora dominante. E ganham espaço o trabalho com formas e gêneros interventores, híbridos, com vocação publicística acentuada, por meio dos quais o autor busca bases sócio-políticas de difusão da sua crítica. Isso se manifesta, em particular, no ensaio "O cinema e Os fuzis" (1966) e nas publicações da revista Teoria e Prática (1967-1968), vinculados mais diretamente às expectativas de resistência à contrarrevolução preventiva em curso.

Nesses trabalhos, que são discutidos no terceiro capítulo, Schwarz reformula em parte procedimentos críticos anteriores, nos quais a postulação de certa indissociabilidade entre obra autônoma e crítica dialética era adotada como horizonte estabelecido para a sua intervenção no contexto brasileiro. Essa procura de pontos de incidência estratégicos na sua realidade imediata, de modo a sustentar o engajamento político, estrutura novos impasses, acirrando-se as modalidades divergentes de percepção social do tempo que orientam a sua crítica. Nos seus conceitos, coexistem a lógica de certa temporalidade cumulativa e ascendente, que se quer apoiada no conflito e na consciência coletiva, e a verificação de um presente que parece enredado numa reprodução ampliada de si mesmo, desprovido da dialética forte de oposições entre indivíduo e sociedade. Esse regime de historicidade bifronte sustenta, em 1964, o que foi apontado pela crítica como a sua primeira tentativa de caracterização 
nacional, condensada na noção de "mistura belmiriana" (referida à prosa de Cyro dos Anjos). Ainda no final do percurso acompanhado nesta tese, Schwarz entrevê certa inadequação histórica da própria crítica progressista da falsa consciência. Trata-se de um problema que ganharia formulação própria e decisiva - já no âmbito de um sistema teórico, orientado pela obra de Machado de Assis - durante o seu período de exílio, sob o refluxo da hipótese de uma oposição pelas armas no país.

A Capes (Coordenação de Aperfeiçoamento de Pessoal de Nível Superior) concedeu-me bolsa de estudos que permitiu a realização deste trabalho.

A tese contou com a orientação precisa e segura de Edu Teruki Otsuka, a quem agradeço a paciência com os percalços no caminho. Foi fundamental também o apoio de José Antonio Pasta, em particular pelos seus cursos vivos e pela interlocução exigente e fraterna. Agradeço ainda à leitura crítica feita por Paulo Arantes, cujos estudos sobre a obra de Schwarz e os impasses contemporâneos atuam como força motriz para a pesquisa. Também devo muito às sugestões de Anderson Gonçalves, que tentei incorporar, sobretudo, na parte final do texto. E não esqueço a ajuda de Ana Paula Pacheco, cujas questões dirigidas ao projeto, feitas com interesse e rigor, contribuíram para o início da escrita. Gostaria de mencionar ainda os grupos de estudos "Formas culturais e sociais contemporâneas" e "Sequências brasileiras" (vinculados à FFLCH/USP), espaços importantes para a reformulação de ideias.

Além disso, sou grato a Luiz de Mattos Alves e Rosely de Fátima Silva (DTLLC), pela atenção com os processos necessários para a finalização da tese, e aos funcionários do AC/SIARQ da Unicamp, que me auxiliaram durante o trabalho com a documentação do autor.

Aproveito aqui para registrar também a generosidade intelectual de Roberto Schwarz, que aceitou gentilmente - uma vez mais - discutir aspectos da sua obra para um escrito de formação acadêmica.

Por fim, dedico este trabalho à minha companheira Thais, que soube mesmo navegar las verticales olas. 


\section{Capítulo I}

\section{Um jovem materialista e o tempo sem História}

\section{De costas para o tempo do mundo}

Ao examinar em 1959 os sentidos do romance Abdias (1945), de Cyro dos Anjos, o jovem Roberto Schwarz afirma que essa prosa "não tem por objeto o tempo do mundo, mas antes um tempo de ficar velho". ${ }^{1}$ No Suplemento Literário d'O Estado de S. Paulo, esse é o seu primeiro juízo crítico sobre uma forma brasileira. Ele considera o dito "tempo do mundo" como uma "aparição casual" em Abdias. De qualquer modo, a percepção desse caráter espectral da "História" na obra não se configura como um problema estético. Isso porque o referente social seria "exterior" à estruturação do diário. Assim, sob esse paralelismo crítico, Schwarz busca valorizar ali o que ele chama de "tempo de ficar velho", supondo a vigência de um ponto de vista que distingue e ordena o passado, distanciando a sua matéria social num "trajeto de objetivação". Essa é a hipótese da mediação narrativa, na qual vigoraria o suposto movimento reflexionante do livro. ${ }^{2}$ Segundo o seu esquema, Abdias supera $O$ amanuense Belmiro (1937). O romance de estreia de Cyro dos Anjos teria internalizado uma dissociação rígida entre o "antitempo do marasmo, do cotidiano", e o "tempo da paixão" subjetiva, cujo estatuto seria meramente "excepcional". Para o crítico, no Amanuense "o tempo existe (...), quando acontece história; e apaga-se quando os dias se tornam iguais". 3

\footnotetext{
1 “Tempo de ficar velho”. In: Suplemento Literário d'O Estado de S. Paulo, 31. jan. 1959, p. 39 (esse texto está

${ }^{2}$ Schwarz distingue três planos de narração em Abdias: a "mocidade e infância rural", o "tempo anterior à história relatada" e o "tempo que preside a elaboração do diário". E considera que esse último possui uma "importância menor" para o exame da obra, pois ele já estaria orientado pela "conveniência didática" na exposição do mundo narrado, a partir da qual se manifesta a "sábia presença de Cyro dos Anjos". Ibidem, p. 39.

${ }^{3}$ Ibidem, p. 39.
} 
No caso do Amanuense, é o próprio ponto de vista narrativo que se mostraria impermeável ao desdobramento da racionalidade histórico-social, segundo a leitura de Schwarz. Haveria ali algo como uma justaposição de durações que erram. São sequências que, aparentemente, não se deixam inscrever num devir temporal orientado. Nesse módulo de composição, certa superfície lisa e sem espessura, da ordem do sempre igual, não permite articular quadros narrativos. Desse modo, a obra configura-se a partir da supressão intermitente da sua temporalidade histórica. $\mathrm{Na}$ definição de Schwarz, o tempo para Belmiro é o "tempo da paixão", separado da aparência de "antitempo" do cotidiano, e imediatamente vinculado à história. Ante essa dinâmica entravada, Schwarz vê, sobretudo, uma negação do sensível, que teria limitado a simbolização da realidade social. ${ }^{4} \mathrm{E}$ aponta para o registro insubsistente e mesmo informe do tempo no Amanuense. No seu corpo a corpo inicial com a matéria histórica brasileira, o crítico busca desentranhar contornos "tangíveis, plásticos, portadores de uma realidade que supera de muito a simples evocação". 5

Schwarz acredita encontrar essa disposição narrativa em Abdias, que seria dotado de uma perspectiva "ampla". Segundo ele, há dois modos de configuração da temporalidade que "se debatem" nessa obra. Ao tempo "heroico", associado pelo crítico ao tema do amor impossível, contrapõe-se um registro "sólido", o "tempoformiga" da prática cotidiana. O percurso de Abdias teria posto em relevo uma concatenação apurada da "ação", unificando os seus elementos antagônicos numa sequência de tempo vivido. A representação ativa do "herói mineiro da vida menor" sedimenta-se aqui na forma própria do relato, segundo Schwarz. Assim, haveria um nexo "mais rico e complexo" entre a prioridade objetiva da práxis, o processo de

\footnotetext{
${ }^{4} \mathrm{Na}$ conceituação clássica das mediações, esquematizada por Lukács, as "formas imediatamente dadas dos objetos, sua existência e seu modo de ser imediatos aparecem como o que é primeiro, real, objetivo, enquanto suas 'relações' se mostram como algo secundário e meramente subjetivo. Para esse imediatismo, toda modificação real deve representar algo incompreensível. O fato inegável da modificação se reflete, para as formas de consciência do imediatismo, como catástrofe, como mudança brutal e repentina, que vem do exterior e exclui toda mediação. Para poder compreender a mudança, o pensamento deve superar a separação rígida dos seus objetos; deve colocar suas inter-relações e a interação dessas 'relações' e das 'coisas' no mesmo plano de realidade. Quanto mais se distancia do simples imediatismo, mais se estende a malha dessas 'relações', quanto mais completa a integração das 'coisas' ao sistema dessas relações, mais a mudança parece perder seu caráter incompreensível, despojar-se de sua essência aparentemente catastrófica e tornar-se, assim, compreensível". "A reificação e a consciência do proletariado". In: História e consciência de classe: estudos sobre a dialética marxista. São Paulo: Martins Fontes, 2003, pp. 316-7.

${ }^{5}$ São termos utilizados na sua análise estilística de Morte em Veneza (1912), publicada no final de 1958. Para Schwarz, os objetos de Thomas Mann são configurados a partir da "memória meticulosa e sensual das coisas", que "se auto comenta", o contrário mesmo de uma temporalidade "sem história". Essa dialética da apresentação Morte em Veneza teria produzido um lirismo próprio, caracterizado pela exatidão e pela minúcia narrativa. Trata-se, afinal, de um consciente e metódico "particularizar das sensações", segundo Schwarz. Cf. "Linguagem de uma novela". In: Suplemento Literário d'O Estado de S. Paulo, 20 dez. 1958, p. 33.
} 
reprodução da vida, e a interioridade da personagem. ${ }^{6}$ Desse modo, os acontecimentos narrador seriam submetidos à prova do mundo exterior. Apreendido em situação, isto é, a partir das suas condições materiais de existência, o narrador reconhece um outro universal e abstrato que é formalmente igual a si mesmo. Schwarz vincula a matéria de Abdias a essa lógica recursiva-progressiva de equivalências, que orienta a norma burguesa da subjetividade exigente. E, a partir disso, projeta na trajetória desse "fazendeiro do ar" a assimilação prosaica dos objetos.

Daí a diferenciação inicial do crítico, que serve à valoração estética: "O que para Belmiro seria estagnação, para Abdias permanece como tempo". ${ }^{7}$ Em ambas as obras, Schwarz presume um narrador na condição de indivíduo isolado. ${ }^{8}$ Mesmo no Amanuense, a sua tentativa de identificação de uma temporalidade algo evanescente aponta para uma suposta subjetividade contemplativa de Belmiro, que não aceitaria senão o que lhe é intrínseco. Nesse aparente insulamento do "eu", que não encontraria em si uma existência concordante com a sua natureza, haveria certa incapacidade genérica para exteriorizar as intenções em práticas. ${ }^{9} \mathrm{Na}$ medida em que o fundamento desse impasse permanece difuso, destaca-se no Amanuense a ausência de uma síntese poética entre a necessidade submetida a leis num fenômeno particular e a totalidade contingente, descompasso que daria certa margem à arbitrariedade formal. Assim, a racionalidade realista do pormenor teria submergido ali na mera singularidade privada. Como se vê, são notações críticas que já indiciam uma estrutura narrativa

\footnotetext{
${ }^{6}$ As expressões entre aspas são de Schwarz. Cf. “Tempo de ficar velho”, op. cit., p. 39.

${ }^{7}$ Ibidem, p. 3.

${ }^{8}$ Como demonstra Georg Simmel, o conceito de sujeito isolado, próprio da sociabilidade burguesa, "adquire seu sentido unívoco e positivo na medida em que é considerado como um efeito de distância social - mesmo que sob forma de sobrevivência penosa do passado, de antecipação de contatos futuros, de nostalgia ou de intencional voltar às costas à sociedade. (...) A desvinculação - como comportamento social negativo - quase nunca é um calmo possuir da liberdade, mas antes é um contínuo abandonar de laços que estejam, de momento, a limitar a autonomia do indivíduo, ou que tendam a fazê-lo". Cf. "O indivíduo e a díade". In: Cardoso, Fernando Henrique; Ianni, Octávio (orgs.). Homem e sociedade. São Paulo: Companhia Editora Nacional, 1961, p. 137 e 140.

${ }^{9}$ O problema da "exteriorização" da existência, e de sua dramatização pública, é retomado na análise da poesia de Mário Chamie. Lendo o poema "No centro", publicado em Os Rodizios (1958), Schwarz afirma que o eu lírico se caracteriza inicialmente "por não ir; não atende a nenhum chamado". Nos termos do crítico, "trata-se de um "ficar' absoluto, desligado da espécie das solicitações". No entanto, Schwarz identifica uma superação efetiva, que tira o em si dessa noite da identidade. Ele postula que esse sujeito entra em "diálogo" com os objetos, engendrando um "processo de auto-superação, de auto-encontro, de encontro com a poesia". Nessa ação de retorno do mundo ao sujeito, há uma passagem que "funda parte de sua riqueza na multiplicidade dos entendimentos possíveis". Essa seria a perspectiva "centrada" da poesia antirretórica de Chamie, tomado como contraexemplo do vago simbolista, e que organiza as sensações imediatas e orienta a "leitura exata do pormenor". O correspondente ético-político desse "auto-encontro" dialogado do "eu" na sua poesia, postulado por Schwarz, seria um mundo social posto em movimento graças ao impulso de consciências individuais livres, distintas das coisas e distintas entre si. Cf. "No centro: Mário Chamie”. In: Suplemento Literário d'O Estado de S. Paulo, 18 abr. 1959, p. 35.
} 
diversa daquele "conteúdo social vivo e gerador de formas", que funda o romance como gênero. ${ }^{10}$ Em 1959, contudo, essa atrofia do Amanuense, a sua temporalidade desconjuntada, é vista por Schwarz como um defeito de composição, posteriormente corrigido pelo próprio autor em Abdias (que é o foco principal do artigo).

Ainda assim, ele admite de passagem que em Abdias também são raros os "momentos de ação simples". ${ }^{11}$ Segundo o crítico, a questão central do livro encontrase numa "constante transparência do presente em direção ao passado", que seria um aspecto constitutivo das personagens de Cyro dos Anjos. As suas referências à "mistura passado e presente" na obra (fala-se também em "conjugação", "superposição" e "interpenetração" de temporalidades) adquirem um sentido mais preciso ao longo da argumentação. "À rápida descrição, acúmulo de fatos”, explica Schwarz, "segue-se o mergulho no passado", conduzido por uma voz narradora "incapaz da vida irrefletida", de acordo com os seus termos. A disposição analítica, ancorada num sujeito que duvida, serviria aqui ao reconhecimento do passado. Diz Schwarz: "Da conjugação dos tempos, (...) nasce o sentido da ação, nem pura resposta ao estímulo imediato, nem mergulho em labirinto sem volta". ${ }^{12}$ Assim, a sua percepção de uma "transparência" temporal em Abdias remete a um suposto devir interiorizado, que reincorpora a experiência vivida, implicando superação de si e autocrítica da realidade presente.

A partir do reconhecimento desse narrador auto idêntico, fundador de práticas de conhecimento, Schwarz vê uma diferenciação efetiva entre o mundo subjetivo e o objetivo. Ou seja, essa prosa não se conforma ao subjetivismo e nem se perde - para falar como Lukács - no "intrincado dos detalhes em si e para si equivalentes". 13 Segundo Schwarz, Abdias opera a partir de uma relativa estabilização da memória individual. Trata-se, assim, de uma mediação que mitiga o peso excessivo do presente e o tensiona para uma dimensão aberta de futuro, sustentando a variedade contraditória dos possíveis. Nesse sentido, a narrativa se afasta da descrição abstrata

\footnotetext{
${ }^{10}$ Lukács, Gyorgy. “Nota sobre o romance”. In: Georg Lukács: sociologia. São Paulo: Ática, 1981, p. 177.

${ }^{11}$ Cf., por exemplo, esta observação de Schwarz: "Abdias tem reminiscências e nostalgias do interior mineiro, da 'estabilidade da vida em Várzea dos Buritis'; ao mesmo tempo, e daí sua complexidade, usa de expressões irônicas e moderníssimas, como o 'sentimento de menos-valia' - conceito psicanalítico acrescido da alusão à mais-valia marxista". "Tempo de ficar velho", op. cit., p. 39.

${ }^{12}$ Ibidem, p. 3.

${ }^{13}$ Lukács, "Narrar ou descrever?" In: Marxismo e teoria da literatura. São Paulo: Expressão Popular, 2010, p. 166.
} 
do quadro meramente observado, enquanto elemento estático e indiferenciado. Schwarz sustenta o tempo todo a conexão entre essa ordenação do passado e o avanço da ação narrativa em Abdias, o que teria tornado inteligíveis as fusões fantasmagóricas da reificação. Para o crítico, a superação dessa existência heterônoma produz na obra um sentido mesmo de "apaziguamento":

Quanto ao paralelismo de estilo e trama: a partir da reconciliação de Abdias e Carlota, principalmente após a morte desta, toma a frase um andamento mais largo. A nova atmosfera não se deve, apenas, às palavras novas (a morte pede outros termos, é claro); trata-se, isso sim, de um contraste rítmico face à narrativa anterior. A vírgula frequente, a guinada súbita do pensamento, o termo desusado, são todos instrumentos do pé-atrás, da autoironia que frente à morte se dilui. $\mathrm{O}$ texto fica como que apaziguado. ${ }^{14}$

Schwarz entrevê aqui uma lógica de atenuação dos embates entre o "eu" e o mundo na prosa de Cyro dos Anjos. Não se externa o entrechoque de vontades, e falta o presente de um confronto intersubjetivo entre as personagens. No entanto, esses motivos "apaziguados" são lidos como "contrastes rítmicos". Assim, o ensaio tende a encapsular a autonomia relativa que esse balanceio de temporalidades sociais assume no plano estilístico. Essas oscilações no ponto de vista narrativo são interpretadas como uma diversificação heurística dos ângulos de abordagem do objeto. Para Schwarz, a suposta perspectiva compreensiva desse narrador sobre o mundo empírico, suscitando os momentos essenciais que determinam uma trajetória subjetiva, vinculase à "maestria" técnica do autor. Cyro dos Anjos teria dominado, efetivamente, a sua matéria social. Sob esses termos, a variada interpenetração dos planos de observação e de narração em Abdias, que impressiona o jovem Schwarz, recebe um comentário breve. $\mathrm{O}$ crítico valoriza a beleza difícil dessas alternâncias narrativas, pontuando a sua função na economia interna da obra. Esses deslocamentos pendulares teriam constituído uma "multiplicidade" de mediações, que encadeiam o desenvolvimento da personagem principal. Na suposta profundidade temporal de Abdias, Schwarz vê a amplitude épica que destrona o acaso, torna-o necessário, numa tensão renovada a cada passagem cumprida.

\footnotetext{
${ }^{14}$ Schwarz, "Tempo de ficar velho", op. cit., p. 39.
} 
Desse modo, Schwarz se identifica à vox humana do narrador. No final do enredo, Abdias diz reconhecer a unilateralidade das suas paixões, que o teriam levado a considerar os fenômenos pela aparência: "Não nos abismos, mas no altiplano da consciência é que há de fazer-se a devassa final". ${ }^{15}$ Ao definir esse gesto como "moralista", Schwarz supõe a individualidade exclusiva que encontra um ponto de apoio para si. Ou seja, esse sujeito discrimina e passa juízo sobre a sua experiência, desdobrando-se num contínuo inteligível até outra exterioridade social. Nesse desengano prático, de acordo com a boa fórmula de Schiller, "pela sequência de suas representações, o eu que perdura torna-se fenômeno para si mesmo". ${ }^{16}$ De fato, esse homme de lettres local, algo como um "fazendeiro do ar" experimentado, torna-se o seu próprio limite, coincidindo consigo mesmo. ${ }^{17}$ A partir desse acúmulo progressivo, ainda segundo a leitura de Schwarz, Abdias se apresenta como a figura mesma do "Professor", aquele que tem "forças para a decisão". ${ }^{18}$ No telos desse "tempo de ficar velho", as "multiplicidades" do mundo narrado aparecem positivamente orientadas para o futuro. Contudo, desprovido da matéria social que lhe define o sentido, esse primado do devir e a sua vindicação de totalidade instauram uma espécie de "dialética das ideias puras". ${ }^{19}$ Refutando imediatamente a noção de imediatidade, sem a interposição objetiva de uma certa camada histórica, Schwarz postula a identidade da experiência de Abdias por um processo de autoconhecimento individual.

\footnotetext{
${ }^{15}$ Anjos, Cyro dos. Abdias. São Paulo: Globo, 2008, p. 180.

${ }^{16}$ Desde um ponto de vista fundado na esfera da moralidade individual, a partir do qual a viabilidade desse eu que se torna "fenômeno para si mesmo" configura-se como um problema pedagógico, Schiller sintetiza a trajetória formativa prescrita pela filosofia estética idealista alemã. "O homem tem, primeiramente, de receber a matéria da atividade ou a realidade (que a inteligência suprema haure de si mesma), e ele a recebe, pela via da percepção, como algo existente fora dele, no espaço, ou como algo alternante nele, no tempo. Essa matéria que nele alterna é acompanhada por seu eu que nunca alterna - e permanecer sempre ele mesmo em toda alternância, isto é, fazer das percepções a experiência, a unidade do conhecimento, e de cada uma das espécies de fenômeno no tempo a lei de todos os tempos, esta é a prescrição que lhe é dada por sua natureza racional. Na medida somente em que se modifica, ele existe; na medida somente em que permanece imutável, ele existe. O homem, pois, representado em sua perfeição, seria a unidade duradoura que permanece eternamente a mesma nas marés da modificação". O contexto de Schiller, como se sabe, é o início do processo de divisão social do trabalho e de burocratização do intelectual. Cf. A educação estética do homem: numa série de cartas. São Paulo: Iluminuras, 2011, pp. 60-1 (grifos do autor).

${ }^{17}$ Nesse sentido, Schwarz vê em Abdias aquilo que ele exigiria em Kafka, por exemplo. Ou seja, a materialidade de um processo dialético de superação, a partir do qual o "significado subjetivo de uma ação é retificado ou contrariado pela medição da exterioridade, pela consequência prática na qual encontra o seu significado objetivo". Nessa dinâmica, o "primeiro momento, de inteligibilidade imediata, é irremediavelmente contaminado pelo segundo, cuja inteligibilidade é mediata: do choque das significações originais nascem outras, novas, cuja captação exige o esforço renovador da parte de quem as experimenta". Em suma, trata-se da experiência da "História" na obra, tornando "lenta e pesada a dialética das emoções". Cf. "Uma barata é uma barata é uma barata" (1961). In: A Sereia e o desconfiado. Rio de Janeiro: Paz e Terra, 1981, p. 67 e 69 (grifos do autor).

${ }^{18}$ Schwarz, "Tempo de ficar velho", op. cit., p. 39.

${ }^{19}$ Engels, Friedrich; Marx, Karl. A ideologia alemã. São Paulo: Boitempo, 2007, p. 231.
} 
Mais recentemente, Schwarz deu notícias de um comentário anterior sobre $O$ amanuense Belmiro, que teria sido publicado em 1958 no jornal Última Hora. ${ }^{20} \mathrm{Na}$ ocasião, ele era aluno de Antonio Candido, que ministrava na USP a disciplina "Organização Social do Brasil”, o seu último curso na área de Sociologia. Em entrevista, Schwarz avalia que os seus textos de juventude sobre Cyro dos Anjos o ajudaram a se aproximar de Candido (que sempre estimou o Amanuense). De fato, "Tempo de ficar velho" impregna-se dos argumentos e do vocabulário do autor de "Estratégia", até então o "rodapé" mais percuciente sobre a estreia do escritor mineiro. ${ }^{21} \mathrm{O}$ pressuposto de Candido, por ora incorporado pelo aluno, é de que a voz narradora no Amanuense encontra-se num "estado de paralisia por excesso de análise". ${ }^{22}$ Trata-se, assim, de um superávit de "vida interior". Nesse sentido, Candido reconhece um "movimento de báscula" na lógica compositiva, alternando-se entre a evasão da vida material e o desdobramento moderno da reflexividade de si. Para ele, o um-no-outro "lírico" e o humour analítico distanciado entram em "diálogo" nessa obra. Nas recordações desse "psicólogo lírico", diz Candido, não pode vigorar o titanismo balzaquiano, fundado na ação do "homem que não se lembra, que cresce num impulso vegetal, sem a peia do passado". ${ }^{23}$ E tampouco subsiste o ato de "viver integralmente no mundo recriado pela memória", à maneira objetiva da reordenação experimental proustiana. Isso porque a "sensibilidade" de Belmiro joga-o "como uma bola entre o passado e o presente", o que "não lhe permite uma existência atual", segundo Candido. ${ }^{24}$ Esse balanceio teria resultado num "maravilhoso sentido poético das coisas e dos homens", distinto da "visão dramática" de um Machado de Assis. ${ }^{25}$

\footnotetext{
${ }^{20}$ Esse texto, recomendado por Jacó Guinsburg à redação do jornal, teria sido veiculado na coluna de Ricardo Ramos, filho de Graciliano Ramos. Infelizmente, o material não foi localizado no "Fundo Última Hora", que integra o Arquivo Público do Estado de São Paulo. Diz Schwarz: "Uma amiga espoleta levou o trabalho ao professor (Candido), contando que eu achava o artigo dele parecido com o meu. Ele achou graça, leu e me convidou para colaborar no Suplemento Literário do Estadão, que era dirigido pelo Décio de Almeida Prado. Assim, quando fui a Assis procurar conselho, ele tinha ideia do que eu andava fazendo. (...) Ficou mais ou menos combinado que quando eu terminasse o curso faria um mestrado em Literatura Comparada no exterior e depois iria trabalhar com ele na USP". Cf. "Na periferia do capitalismo" (entrevista). In: Martinha versus Lucrécia. São Paulo: Companhia das Letras, 2012, pp. 284-5.

${ }^{21}$ Quando escreve esse rodapé, Candido era "crítico titular" na Folha da Manhã. Cf. "Estratégia" (1943). In: Brigada ligeira. Rio de Janeiro: Ouro sobre Azul, 2004, p. 76.

${ }^{22}$ Ibidem, p. 76.

${ }^{23}$ Ibidem, p. 82.

${ }^{24}$ Ibidem, p. 75.
} 
O comparatismo de Candido destaca no Amanuense o seu momento de "equilíbrio". Ele se refere, assim, à própria autoconsciência formal, que teria conferido ao romance o seu aspecto "estratégico". Para o crítico, o ponto de vista narrativo está "sempre a tomar consciência plena das suas variações e dos seus aspectos múltiplos". ${ }^{26}$ A obra teria apreendido um processo desmedido de reflexão, que precede e subordina a percepção dos dados imediatos da vida prática, sob o problema abrangente da "tenuidade nacional". ${ }^{27}$ Nesse tempo "presente que cede ante a ponta aguda da análise" de Belmiro, segundo os termos de Candido, a constituição do juízo autônomo, bem como a verificação objetiva dos interesses em disputa, coexistem com certa indistinção "terna" entre sujeito e objeto. "O velho Borba, Silviano, Redelvim, Florêncio, Glicério são outros tantos eus que poderiam ser ele próprio", diz Candido. ${ }^{28}$ Assim, o mundo narrado não se emancipa do discurso de Belmiro, esfumando-se a demarcação entre o vivo e o morto. ${ }^{29}$

Candido relaciona esse desdobramento da voz narradora ao processo histórico de "belmirização" do intelectual no país, um confinamento socialmente produzido,

\footnotetext{
${ }^{25}$ A postulação direta de uma essência machadiana no Amanuense, convertendo formas historicamente condicionadas em constantes, foi o tópico mais obcecante da fortuna crítica dessa obra. Candido busca exatamente especificar os termos dessa comparação. Ainda assim, o crítico afirma que o Amanuense "empresta uma qualidade de vida que é superior à de Machado de Assis", sem definir se essa forma é mais real. Outro comentário de exceção foi feito por Nelson Werneck Sodré, que tem um ponto de vista hesitante e cheio de interesse. Em 1937, ele vê semelhanças entre Cyro dos Anjos e Machado no "modo de contar, o mesmo desencanto das coisas, o mesmo absenteísmo". E aponta no Amanuense um humour "suave e brando, sem gravames, sem irritações. Tal qual em Machado". No entanto, também acrescenta em seguida: "Mais suave talvez do que em Machado que, de quando em vez, como quem não quer dizer nada, dizia coisas terríveis, coisas mortificadoras, coisas destruidoras". Citado por Nobile, Ana Paula Franco. A recepção crítica de O amanuense Belmiro, de Cyro dos Anjos (1937). São Paulo: Annablume, 2005, p. 69. A afirmação de Candido encontra-se em "Estratégia", op. cit., pp. 76-7.

${ }^{26}$ Candido, "Estratégia", op. cit., p. 76.

${ }^{27}$ A expressão é de Augusto Meyer, repercutindo uma questão clássica na tradição crítica brasileira, de modo a sinalizar uma disposição intelectual que não se articula no tempo próprio de uma tradição; ou nos moldes de um "sistema literário", conforme exposto na Formação da literatura brasileira. No caso do Amanuense, porém, Candido traduz esse impasse enquanto prévia "aplicação do conhecimento aos atos da vida", o que levaria esse literato in erba a uma solução meramente "intelectual" das contradições. Candido, "Estratégia", op. cit., p. 77. Cf. Meyer, "Alencar e a tenuidade brasileira”. In: Obra completa. Rio de Janeiro: Aguilar, 1964, v. II, pp. 11-24.

${ }^{28}$ Contudo, ele reitera que essa proliferação de duplos seria um índice de consciência da dissolução do "patriciado rural" e da vida urbana desagregada. "Apostilas ao Amanuense". Folha da Manhã. São Paulo, 08. out. 1944, p. 7.

${ }^{29}$ Perfazendo algo da ambivalência que caracteriza o objeto, o crítico apresenta como símile do romance uma imagem musical, que embala uma "atmosfera branda e tépida" de adormecimento. Nela, retrata-se a generalidade do ato criador na figura do sanfonista da Vila Caraíbas. Lidando com o "problema do homem", as palavras no Amanuense insinuam-se "lentamente na sensibilidade, até se identificarem com a nossa própria experiência", num "movimento de afinação", segundo os termos de Candido. "Estratégia", op. cit., p. 79. Para a íntegra da cena fusional referida por Candido, ver: Anjos, Cyro dos. O amanuense Belmiro. São Paulo: Globo, 2006, p. 28.
} 
que o tornaria desfibrado para o reconhecimento político da barbárie brasileira. ${ }^{30}$ No início dos anos 1940, preocupa Candido o refluxo personalista no campo literário nacional. Após um período de rotinização das tendências estéticas modernistas pelo romance de 1930, que prosseguia ao seu modo o desrecalque de alternativas locais, a literatura brasileira parecia se retrair em si mesma, ameaçando perder-se o tom social conquistado anteriormente. Ao mesmo tempo, o declínio do Estado Novo prometia novas possibilidades de participação aos intelectuais. De fato, em breve se renovaria a confiança no completamento da modernização local, lastreada pela industrialização ascendente e pela luta contra o subdesenvolvimento. ${ }^{31}$ Assim, a percepção de um "equilíbrio" na báscula belmiriana também reverbera a seu modo a hipótese de superação do "atraso", com a integração das classes subalternas às garantias civis. Para Candido, "belmirizar" significava se opor ao "desenvolvimento dialético da personalidade e da sociedade, procurando brecar o vir a ser por meio do prolongamento indefinido das oposições do ser e do não-ser". ${ }^{32} \mathrm{O}$ crítico acreditava que Cyro dos Anjos tinha dado forma a esse truncamento. O jovem Schwarz, por sua vez - a partir desse quadro prático e teórico -, busca extrair o contrário mesmo dessas batidas pendulares exasperantes do Amanuense, para sustentar em Abdias a tese de uma "transparência" entre o tempo passado e o presente, que se tentou discutir aqui.

\footnotetext{
${ }^{30}$ É posterior o famoso elogio drummondiano da fusão "burocrata-escritor" no Brasil. Para Drummond, esse vínculo estatal possibilitaria alcançar certa perspectiva da "mediania", apta a "refletir na mediocridade de uma vida que não conhece a fome nem o fausto". Isso supõe a formação de uma tradição "meditativa e irônica, certo jeito entre desencantado e piedoso de ver, interpretar e contar os homens". A argumentação concentra-se num percurso autor-público ideal, no qual as obras desse "escritor-homem comum" - como um "sopro mágico" - arrebatam "igualmente prisioneiros de outras rotinas, por este vasto mundo de obrigações não escolhidas". Sob o abrigo do Estado, esse sujeito construiria um "edifício de nuvens, como um louco manso e subvencionado". E, ao mesmo tempo, "engrandece (...) a Ordem Burocrática". Essa ordem, então, "situa-o, protege-o, melancoliza-o e inspira-o", diz Drummond. Nesse circuito benigno, justifica-se o lugar de um tipo social fundante das letras brasileiras, sem evidentemente eliminar as suas contradições práticas. Andrade, Carlos Drummond de. "A rotina e a quimera" (1948). In: Passeios na ilha. Cosac Naify, 2011, pp. 109-12.

${ }^{31}$ Cf., por exemplo, o seu rodapé "Esclarecendo", publicado em 9 abr. de 1944: "Devido ao desenvolvimento das suas contradições internas, a burguesia entrou em crise e, com ela, as suas ideologias. Nada mais natural que a crise se manifestasse no romance, um dos instrumentos mais autênticos destas (...). Estas contradições, que se apresentam de um ponto de vista dinâmico como forças de desagregação do equilíbrio existente, entraram a se afirmar com mais vigor. A ruptura do nexo lógico, de certas condições de construção, do caráter narrativo ou descritivo da análise, etc., levou o gênero ao impasse em que hoje o vemos. Anarquizado, escapando aos quadros que o contiveram cerca de dois séculos, atirando-se à busca de novos campos, numa aventura que é das mais grandiosas da história literária, o romance é bem reflexo da crise estrutural e ideológica da burguesia". Candido, Antonio. "Esclarecendo". In: Notas de crítica literária. Literatura e Sociedade. São Paulo, n. 5, 2000, p. 189.

${ }^{32}$ Cf. o seu ensaio sobre A marca (1944), de Fernando Sabino. "Roda de peru”. In: Brigada ligeira, op. cit., p. 86.
} 


\section{2. À procura do narrador}

Os seus ensaios seguintes já buscam modos de aproximação para objetos em que o "tempo não é dimensão estruturada", ${ }^{33}$ algo recusado in limine no item anterior. De janeiro de 1959 a agosto de 1961, ano em que Schwarz vai para Yale cursar o mestrado em Literatura Comparada e Teoria Literária, ele elabora seis estudos sobre obras brasileiras. "Tempo de ficar velho" e "No centro: Mário Chamie", os dois primeiros dessa série, seriam excluídos da compilação feita em 1965 para A Sereia e o desconfiado. De fato, viu-se como esses artigos compartilham os mesmos pressupostos teóricos. A partir de uma dinâmica positiva de desengano entre o sentido de relações sociais basilares e os dados imediatos da vida cotidiana, a consciência narrativa local é vista como nitidamente configurada. Nos seus textos seguintes, já se impõe como parâmetro estratégico de leitura, em seus lineamentos gerais, aquilo que o jovem Schwarz entenderia como o "desdobramento realista da vida", a partir do qual necessariamente a "situação engendra a situação e a última refaz as anteriores". 35 Para ele, a forma-romance mobiliza no seu princípio compositivo as categorias que lhe servem de fundamento. Essas passam juízo sobre si mesmas, e lhe definem a medida e o alcance. Movendo-se entre possibilidades objetivas, e evoluindo do conflito presente para o futuro, a obra realista pode figurar as forças motrizes que determinam a sua matéria, vindo à tona a dialética entre o anseio individual e os limites da sociedade.

Todo romance começa em meio da linguagem e das noções comuns. Passo a passo constrói contextos singulares, no interior dos quais as palavras e as ideias adquirem e cristalizam certos aspectos, enquanto excluem outros. Evoluindo através de situações concretas, as noções provam ser verdadeiras, falsas, ou têm reformulado o seu sentido. Na consistência e importância desta evolução mede-se o poder de pesquisa e descoberta que um romance acaso tenha. O romance tem compromisso, pois, com os significados que se estabelecem em seu curso. Coerência, nesse sentido, é um nome técnico para profundidade de pensamento. Uma vez delimitadas, as noções não mais deveriam aparecer com os significados anteriores à sua determinação; se o

\footnotetext{
${ }^{33}$ Retiro a expressão, que se repete nos textos do jovem Schwarz, de "Existencialismo e romance histórico (Malraux)". In: A Sereia e o desconfiado, op. cit., p. 98.

${ }^{34}$ Para a relação completa dos seus textos até “As ideias fora do lugar" (1972), ver “Anexos”.

${ }^{35}$ Como se verá, essa dinâmica não corresponderia apenas ao romance europeu do século 19, que serve como uma referência fundamental. Cf., por exemplo, a introdução de "Uma barata é uma barata é uma barata". In: A Sereia e o desconfiado, op. cit., p. 59.
} 
fazem, perderam-se os esforços do romance, e recaímos na chatice do senso comum. Falta de consistência interior e superficialidade são uma coisa só. ${ }^{36}$

Essa sua breve conceituação da forma-romance baseia-se na possibilidade de uma imanência estrita das significações. ${ }^{37}$ A construção de uma trama cerrada, orientada pelo decurso da ação, unificaria de modo concreto as "noções comuns" e antagônicas da obra, pondo à mostra distinções que permitem uma organização mínima do tempo. O pressuposto é a fricção social continuada das ideias, sempre inscritas numa constelação prática. Dado esse vínculo forte entre a vida ideológica e a realidade material, que supõe um determinado desenvolvimento histórico, bastaria à configuração artística "entregar-se" ao curso lógico da sua matéria histórica, que não é imediatamente dado. A partir desse procedimento disciplinador das formas, o desdobramento pleno da situação - ou seja, do nexo rigoroso e inteligível que rege os atos numa sociedade contraditória - constituiria o triunfo do realismo e a verdade do ponto de vista narrativo, para além da consciência teórica do autor. No romance europeu do século 19, por exemplo, a figuração do fracasso da indignação subjetiva produz internamente um "ponto de vista utópico", insinuando uma "situação na qual o coletivo não seja inimigo do desígnio pessoal", segundo as palavras de Schwarz. ${ }^{38}$ Daí a complexidade da imaginação realista - o seu "poder de pesquisa e descoberta" citado no trecho anterior -, que cifra em cada destino individual a "contradição roendo a ordem" existente. ${ }^{39}$ Nessa noção de beleza experimentada, o jovem Schwarz

\footnotetext{
36 “A Letra Escarlata e o Puritanismo”. In: idem, p. 133.

${ }^{37}$ Sobre o contato com a teoria do realismo de Lukács, um dos apoios teóricos de Schwarz, vale o esclarecimento do próprio autor. O crítico afirma que inicia a leitura de Lukács por meio dos estudos sobre o "destino" alemão de Schicksalswende (1943), e dos seus Essays über Realismus (1948). Este último trazia "Narrar ou descrever?", que de imediato impressiona Schwarz. Em 1960, começa a circular a tradução francesa de História e consciência de classe, que seria referência importante no "Seminário Marx”. Diz ele: “(...) Comecei a ler Lukács em 1959, Adorno em 1960 e Benjamin em 1961, sobre fundo de simpatias marxistas que vinham de antes, e graças também às boas livrarias alemãs que havia em São Paulo na época. Tinha notícia de Lukács por meus pais, que tinham frequentado as conferências dele em Viena, na década de 1920. (...) Com Lukács tive a noção do que pode a crítica dialética. Mas como eu gostava especialmente de Kafka e Brecht e aspirava a ser um escritor vanguardista, sempre guardei alguma distância em relação a ele e me sentia mais à vontade com os outros dois, que entretanto eu entendia menos, porque são mais difíceis. Além do que meus pais eram anti-stalinistas por experiência própria, de modo que havia uma parte em Lukács que nunca engoli. Não obstante, aproveitei muito os ensaios dele sobre o romance do século XIX. Enfim, os rótulos não esgotam os autores". Cf. "Tira-dúvidas com Roberto Schwarz". In: Novos Estudos Cebrap, n. 58, nov. 2000, p. 65. Para um resumo das reflexões estéticas de Lukács sobre a "miséria alemã", ver Otsuka, Edu Teruki. "Lukács, realismo, experiência periférica (anotações de leitura)". In: Literatura e Sociedade. São Paulo, 2010, n. 13, pp. 36-45. Ver ainda Frederico, Celso. "A recepção de Lukács no Brasil”. In: Herramienta - Revista de Debate y Crítica Marxista. Disponível em: http://www.herramienta.com.ar/teoria-criticay-marxismo-occidental/recepcao-de-lukacs-no-brasil. Acesso em: 11 jan. 2018.
}

38 “O mano capeta do liberalismo (O Sósia)". In: A Sereia e o desconfiado, op. cit., p. 94.

${ }^{39}$ Ibidem, p. 94. 
valoriza a "ousadia dedutiva, que lê nas estruturas o seu destino". ${ }^{40}$ Para ele, uma vez esboçada essa "direção" constitutiva na obra, que opera uma efetiva experiência acumulada, "tudo que não se prende a ela aparece como falha". ${ }^{41}$

É a partir desse crivo realista, e do seu vigor dialético, que se orienta inicialmente a leitura de um livro como Perto do Coração Selvagem (1943). Nessa estreia de Clarice Lispector, teria vigência uma temporalidade que "comparece para melhor se anular". ${ }^{42}$ Segundo Schwarz, o ponto de vista narrativo configura "momentos" idênticos de uma condição existencial de solidão. Em outras palavras, essa obra supõe um "substrato humano essencial”, sem gênese ou modificação, em tese refratário à dialética do movimento histórico das formas. Para ele, a "vivência fundamental" de Joana, que dita a perspectiva desse romance, coincide com a "diversidade exterior das experiências", numa disposição especular que ata sujeito e objeto. Ao conceituar essa ação que teria se constituído por "acúmulo e insistência", Schwarz reitera a sua ausência de "função histórica". Nos seus termos, o tempo aqui “inexiste como possibilidade de evolução". E a consciência narrativa apresenta-se como "inexorável”, determinada por um circuito presentificado de recorrências. ${ }^{43}$ Desse modo, não se estabelecem totalidades sociais, conforme lamenta o crítico. Contudo, diz ele, é nesse caráter invariante que "melhor reconhecemos a unidade essencial da experiência de Joana". ${ }^{4}$

De fato, após delimitar as premissas da narrativa, a argumentação sofre um giro abrupto, que é pressentido pelo crítico. Diz Schwarz: "São raros os escritores que, desprezando o circunstancial a bem de uma esfera que o preceda, tenham o que dizer. Entre estes, (...) está Clarice Lispector". ${ }^{45} \mathrm{O}$ ensaio busca, então, formular o impasse anterior nos termos de uma "descontinuidade" objetiva. Perto do Coração Selvagem teria configurado a "solidão da consciência em relação à sua base material

\footnotetext{
40 “A Letra Escarlata e o Puritanismo". In: idem, p. 137.

41 "Emília Galotti e o nascimento do Realismo". In: idem, p. 118 e 126.

42 “Entre ser e parecer”. In: Suplemento Literário d’O Estado de S. Paulo, 19 set. 1959, p. 39.

${ }^{43} \mathrm{Na}$ edição em livro, Schwarz acrescentaria que as essências claricianas são "descritiveis, (...) mas inenarráveis, já que não se modificam nem têm gênese". Cf. "Perto do Coração Selvagem". In: A Sereia e o desconfiado, op. cit., p. 53.

44 “Entre ser e parecer”. In: Suplemento Literário, op. cit., p. 39.

${ }^{45}$ Ibidem, p. 39.
} 
(...), o vazio que instala o arbítrio". ${ }^{46}$ Para ele, a obra incorpora de modo consciente esse "hiato", evidenciando um indivíduo que "voa às cegas com olhos abertos". Ao "observar-se", Joana "compreende e ilumina" a sua condição, embora essa lucidez sirva para atestar a sua impossibilidade de desenvolvimento. Assim, o ponto de vista seria "inexorável" e também "imprevisível", orientando-se ainda pela "precisão" moderna e pela "minúcia" psicológica. Schwarz afirma mesmo que a personagem situa-se no "limiar da obra", porém próxima de encontrar em si o seu fundamento. Nessa consciência dobrada, existiria um sujeito que "habita as antecâmaras da poesia, da objetivação do espírito", e o seu outro, "desfeito em processos elementares". ${ }^{4}$ Considerando essa "ambivalência" entre a dubitatividade moderna e o estaticismo do arché - "inteligência" e "núcleo", nos termos do crítico -, ele define que a "total inserção no mundo das coisas" não teria a primazia nessa obra. O ponto de vista permanece "lúcido", e "faz do acaso a sua riqueza", segundo Schwarz. ${ }^{48}$

O crítico aponta apenas uma "falha" estética no livro de Lispector. Ele insiste que o ponto de vista que conforma Joana torna-se "irremediavelmente" idêntico àquele que retrata as demais personagens. ${ }^{49}$ Quando reconhece a não constituição de um "plano narrativo" próprio (o que existem são fragmentos "psicológicos" brilhando "lado a lado sem articulação cerrada"), o crítico vê a ausência da "História" aqui como uma adequação técnica. O nexo frouxo entre os episódios metodizaria as "contraposições estanques" que cindem a voz narradora. ${ }^{50}$ Desse modo, a margem de "arbítrio", apontada no interior do princípio compositivo, seria parte da "coerência" construtiva da obra, fundada na inexistência mesma de uma "estrutura definida". Ante a não-radicação material da consciência, com a remissão da palavra ao mesmo, Schwarz fala numa prosa "estrelada" em Perto do Coração Selvagem. Essa obra “existencial” seria, assim, a "cristalização formal de uma visão do homem, segundo a qual é impossível a passagem completa e coerente dos mecanismos psicológicos mais

\footnotetext{
${ }^{46}$ Ibidem, p. 39 (grifo do autor).

${ }^{47}$ Ibidem, p. 39.

${ }^{48}$ Schwarz quer marcar posição contra a apologia indireta dos recessos da consciência e da dissolução da realidade empírica (exemplificada aqui pela referência a Gottfried Benn), insistindo na intelecção dos processos sociais. Desse modo, mesmo uma obra que despreza o "circunstancial a bem de uma esfera que o preceda", conforme as palavras do crítico, mantém ainda um valor de conhecimento. Ibidem, p. 39.

${ }^{49}$ Ibidem, p. 39.

${ }^{50}$ Ibidem, p. 39.
} 
finos para o comportamento global das personagens". ${ }^{51}$ Nesses termos, a "descontinuidade" apontada pelo crítico remete, afinal, a uma "iluminadora reflexão artística sobre a condição humana". ${ }^{52}$ No elogio à experimentação dessa linguagem, a determinação recíproca entre a verdade formal e a sua prática social fica plasmada num espectro ideológico mais genérico, que parece mesmo não absorver o que mostra a sua análise.

De qualquer modo, a tentativa de apreender certa refração universal no percurso de Joana tangencia consequências gerais da crise histórica da objetividade literária no contexto brasileiro. ${ }^{53}$ Ao mesmo tempo, a crítica sobre Lispector, diferentemente dos seus outros ensaios nesse período, opta por não subordinar o "registro dessa desorientação à integridade virtual do significado". ${ }^{54} \mathrm{Ou}$ seja, o elemento negativo próprio à opacidade e ao incompleto não apresenta aqui, em seu bojo, a referência positiva ausente, "mesmo que apenas implícita, em forma de horizonte, de anseio", como ocorre em outros momentos da crítica do jovem Schwarz. ${ }^{55}$ Nos seus trabalhos seguintes, ele buscaria demonstrar que somente através desse senso de distância torna-se possível a representação do "prejuízo e dano da vida

\footnotetext{
${ }^{51}$ Ibidem, p. 39.

${ }^{52}$ Entre 1959 e 1965, Schwarz muda a "solução" dada a essa descontinuidade ou ambivalência entre "ser" e "parecer". Segundo a versão em artigo, essa superação já estaria, de algum modo, esboçada na própria forma de Perto do Coração Selvagem. E seria dada "através da possibilidade artística ou, de modo mais geral, objetivadora". $\mathrm{Na}$ prosa de Lispector, isso corresponderia aos momentos narrativos em que ocorre a "penetração do cerne elementar pela inteligência", segundo Schwarz. Diz ele: "Chega a ser pungente o livro quando a personagem percebe que irá dizer, que suas impressões, seu amor, seu ser mais íntimo irão se condensar em palavras: o que lhe sai da boca é um doce murmurar de sílabas desconexas". Já na versão de 1965, a possível superação do que Schwarz chama agora de "coincidência" entre "passividade e vigor" vem, sobretudo, pela "possibilidade de agir ou, em nosso caso mais particular, na possibilidade artística". Ibidem, p. 39. Cf. Perto do Coração Selvagem. In: A Sereia e o desconfiado, op. cit., p. 57 (grifo meu).

${ }^{53}$ Ibidem, p. 39.

${ }^{54}$ Como nota Paulo Arantes, um exemplo dessa diferença de tratamento literário mencionada acima são as restrições de Schwarz a André Malraux. Analisando a incorporação da técnica jornalística em A condição humana (1933), Schwarz afirma que o seu apego ao fragmento e ao inacabado é um modo de eternização da "falta provisória de sentido". Diz ele: "Se não for ideado o todo que se esboça em cada ação abortada, que faz dela fragmento de um todo determinado, e não de um todo qualquer, fragmento determinado portanto, os fragmentos serão todos um e o mesmo aborto". A partir do "preconceito irracionalista" de Malraux, segundo o crítico, o fetiche pelo "fato" produz apenas abstração. E a sua intenção de realismo político converte-se em "fim da política", pois destruiria a "multiplicidade do acontecer". Ver "Existencialismo e romance histórico (Malraux)", op. cit., p. 101 e 103 (grifos do autor). Cf. Arantes, Paulo. "A musa do departamento". In: Um departamento francês de Ultramar: estudos sobre a formação da cultura filosófica uspiana. Rio de Janeiro: Paz e Terra, 1994, p. 227 (a citação está aqui).

${ }^{55}$ No seu comentário sobre Henry James, Schwarz afirma que a "crítica negativa diverte, mas é autocitação. Pode ser útil à política literária, delineia o campo, mas não tem contribuição própria". Ver "Retrato de uma Senhora (o método de Henry James). In: A Sereia e o desconfiado, op. cit., p. 151.
} 
negativa", fazendo justiça à "falta de sentido enquanto falta". ${ }^{56}$ Sem essa referência à "plenitude ausente", a narração recairia numa "autoindulgência tagarela, falta-deimportância desimportante". ${ }^{57}$ Em outros termos, as eventuais notações sobre a desvinculação entre consciência e práxis social seriam retidas nas malhas de uma negação indeterminada, e esse puramente negativo não se encontraria no objeto mesmo, conforme acredita Schwarz.

Nos estudos sobre Grande sertão: veredas (1956), tenta-se exatamente divisar na confluência mesma de gêneros, enquanto modo de ser particular da obra, certo movimento interno positivo, que teria tornado coerente a sua passagem direta ao universal. Esse ângulo de abordagem, além de gerar dificuldades objetivas consistentes, empurra o crítico para uma lógica estético-social infensa à síntese. Às vezes no interior de um mesmo parágrafo, esse ensaio reúne observações pioneiras e muito sugestivas sobre a estruturação formal do romance - numa dimensão crítica até então inédita no jovem Schwarz -, ditadas pela sua perspicácia materialista, e interversões sobre a integridade "lírica" de uma consciência narrativa dividida. Um exemplo concentrado desse duplo registro encontra-se na boa percepção de certa técnica de "lançadeira", que seria o princípio organizador da prosa de Guimarães Rosa. O conceito é formulado a partir da explicitação teórica da "ausência relativa do mediador" na obra, que estreita em vários níveis as distâncias entre sujeito e objeto. A "fala" de Grande sertão buscaria, então, absorver o diverso da sua matéria social, marcada por essa "mistura" renitente, na mesma medida em que o seu procedimento narrativo teria aumentado a "importância dos extremos". ${ }^{58}$ Para Schwarz, nesse esforço para conformar um universo linguístico heteróclito, cujo espaço social fraturado objetiva-se pela presença tácita de um interlocutor citadino ante o sertanejo, o discurso na obra:

\footnotetext{
${ }^{56}$ Ibidem, p. 152.

${ }^{57}$ Ibidem, p. 152.

58 “Grande-Sertão em curso”. In: Suplemento Literário, 30 abr. 1960, p. 39.
} 
(...) anuncia uma direção, lança uma "gestalt" que se sobrepõe à gramática e tem força para incorporar, segundo sua dinâmica de sentido, os segmentos mais diversos; estes não precisam entrar em conexão lógica explícita, podem simplesmente se acumular, guardando seu modo de ser mais próprio; não é a sintaxe normativa que determina seu posto, ainda quando com ela concordam; enquadram-se na configuração (referentes, misturadamente, a dados sensíveis e emocionais), visando uma recriação quanto possível integral da experiência. ${ }^{59}$

Não se trata apenas da indicação do caráter não linear de Grande sertão. Esse comentário sobre a dicção narrativa identifica um amálgama interno entre a objetivação das relações sociais e os "dados sensíveis e emocionais". Além do reconhecimento da segmentação extrema do material, Schwarz descreve uma lógica narrativa que se dá por "acúmulo" de pares opostos, na qual não se sedimenta uma normatividade comum. Esses fragmentos pulverizados, "tornados equivalentes", forjariam uma "curto-circuito" poético, segundo a interpretação do crítico. Com os limites "esfumaçados", diz Schwarz, haveria uma "libertação" lírica das sequências narrativas num jorro verbal. E esse fluxo oral, enquanto "totalidade", pode localizar o "sentido de cada segmento". A frase estilhaçada, "liberta de conexões gramaticais secundárias", é reposta "mais solitária e apresenta mais pleno o seu sentido". ${ }^{60}$ Desse modo, Schwarz acredita que essa prosa resguarda a "autonomia da palavra". A configuração roseana desse hibridismo, que "enquadra" os antagonismos sociais, demandaria a integralidade da experiência vivida. E esse anseio instaura-se no próprio núcleo de objetivação do discurso, que tende ao absoluto, como bem nota Schwarz. Daí o ensaio conclui que a plenitude do vocábulo no discurso jagunço seria análoga à conceituação sartreana do poético. Em ambos os casos, a função simbólica e utilitária da linguagem seria renegada em prol da "opacidade, do ser símbolo e gozo dela mesma". ${ }^{61}$ Assim, Schwarz justifica em parte o modo contraditório de um "jagunço 'especular ideias', justapondo Heidegger e buriti”, sem entrar em relação o

\footnotetext{
${ }^{59} \mathrm{Na}$ edição em livro, Schwarz fala em ausência da "conexão gramatical explícita", e não mais em "conexão lógica explícita”. Ibidem, p. 39. Cf. “Grande-Sertão: a fala”. In: A Sereia e o desconfiado, op. cit., p. 40.

${ }^{60}$ Ibidem, p. 39.

${ }^{61}$ Ibidem, p. 39.
} 
"construtivismo da linguagem" e a "fala tradicional de uma população de iletrados", como demonstra Paulo Arantes. ${ }^{62}$

O vislumbre desse salto imediato surge quando Schwarz se arrisca, pela primeira vez, a uma discussão teórica pormenorizada sobre as formas históricas do romance, a partir do cotejo entre Grande sertão e Doutor Fausto (1947). De fato, ele demonstra que em Thomas Mann o devir está efetivamente "orientado". Ou seja, cada passagem da narração carregaria em si a problemática do todo. Para uma personagem como Leverkuehn, as “obras-primas não virão como dádiva sua; a dádiva barganhada refere-se à energia de fazer a própria obra", afirma o crítico. ${ }^{63}$ Assim, Thomas Mann pode interpor uma precisa camada histórica na sua obra, que passa pelo destino da Alemanha, alcançando certa universalidade concreta. Já em Grande sertão, o "saltitar do tempo" entre passado e presente, mais do que "técnica de fazer avançar a trama", remeteria à permanência prodigiosa e primordial do pacto demoníaco. Riobaldo parece "picado pelo destino". ${ }^{64}$ A finalidade explícita do trato fáustico (a morte de Hermógenes) é "estranha ao pactário", colhido numa situação de disponibilidade sem definição. Isso teria resultado numa passagem direta do sertão ao universal, segundo Schwarz. ${ }^{65}$ Nos seus termos, "o que se passa no primeiro é elaboração artística das virtualidades do segundo". ${ }^{66}$ Para ele, essa "ligação direta desobriga o autor de

\footnotetext{
${ }^{62}$ Já Bento Prado Jr., vinculando diretamente as transgressões roseanas à condição "interrogativa" do analfabeto, vê na "autogeração" dessa linguagem o movimento efetivo de uma mediação. "Se é a própria linguagem, em sua dimensão própria, e não na transparência do signo, que é trazida à luz nessa estranha prosa, é compreensível que a linguagem se contorça para auscultar suas próprias entranhas. $\mathrm{O}$ recurso aos modelos da linguagem rústica não é fruto de uma escolha ocasional: essa linguagem, que desconhece a codificação estrita de uma gramática que visa à eficácia operacional, é privilegiada para quem quer retornar àquele brilho das palavras que precede toda ação e prefigura as nervuras do imaginário. É o analfabeto, como o poeta, que consulta o volume interno das palavras, que interroga as franjas que a cercam, na esperança de alimentar a sua sabedoria. Aquém da escrita é que se pode encontrar uma experiência da linguagem semelhante àquela que a literatura procurara restituir: esperança de captar, no puro movimento das palavras, no domínio exíguo que instauram, a verdade do mundo e da experiência”. Prado Jr., Bento. "O destino decifrado: linguagem e existência em Guimarães Rosa". Alguns ensaios: filosofia, literatura e psicanálise. São Paulo: Paz e Terra, 2000, pp. 197-8. A citação encontra-se em Arantes, Sentimento da dialética, op. cit., p. 55.

63 “Grande-Sertão e Dr. Faustus" (Parte II). In: Suplemento Literário, 23 abr. 1960, p. 9.

${ }^{64}$ Contudo, Schwarz diz que nas duas obras a narração configura-se como "corrimão para a leitura”. Ibidem, p. 9.

${ }^{65}$ A sua referência principal, evidentemente, é o ensaio de Candido. O autor de "O sertão é o mundo" (1957) via nessa fusão, o "princípio geral de reversibilidade" da obra, a possibilidade de uma síntese superior, "que nos suspende entre o ser e o não-ser para sugerir formas mais ricas de integração do ser". O que mobiliza fortemente o seu texto é a percepção de uma desprovincianização do dado local, que teria sido configurada por Rosa. Sob um modo diverso, essa expectativa também sustenta a visão de certa fenomenologia jagunça por Schwarz. Em 1966, Antonio Candido já identificaria uma "paridade entre o dilaceramento do narrador e o dilaceramento do mundo". Cf. "O homem dos avessos". In: Tese e Antitese. Rio de Janeiro: Ouro sobre Azul, 2012, pp. 111-30. E "Jagunços mineiros de Cláudio a Guimarães Rosa”. In: Vários escritos. Rio de Janeiro: Ouro sobre Azul, 2004, pp. 99-124.
}

66 “Grande-Sertão e Dr. Faustus” (Parte II). In: Suplemento Literário, op. cit., p. 9. 
qualquer realismo, pois o compromisso assumido pouco se prende à realidade empírica" ${ }^{67}$ Desse modo, a lógica da imediatidade descrita anteriormente seria alheia à dinâmica histórica, que "quase não tem lugar" na obra. Essa ausência, por sua vez, aparece como "virtude", dada a conquista estética da sua coerência interna. ${ }^{68}$

Também no leitmotiv do ensaio sobre $O$ Ateneu se repõe o problema da "anulação do tempo", que se encontraria aqui desprovido da sua diferenciação interna. ${ }^{69}$ Para Schwarz, há uma indistinção hiperbólica entre o narrador e o mundo narrado, "ligados os dois pela emoção". ${ }^{70}$ Essa linguagem dramatizada operaria a partir da indiscernibilidade entre certo objetivismo feroz e o pathos da comoção inflada. No reconhecimento dessa entranhada, e sempre desmedida, "ambiência evocativa" d'O Ateneu, oscilam as categorias de Schwarz. Ele fala ora em "adesão incompativel com a objetividade" ora em "difícil equilíbrio" entre realismo e subjetivismo. ${ }^{71} \mathrm{Na}$ obra de Pompeia, segundo o crítico, o narrador se situa no mundo narrado "engolindo-se", e "fechado sobre si mesmo dá sua própria interpretação". Ao definir a figura central do romance, ele vê em Aristarco o outro "escarnecido" e idêntico ao narrador, cristalizando-se, assim, uma narrativa que "se alimenta de si mesma e não mais de seu objeto". ${ }^{72}$ A respeito dessa junção inextrincável, Schwarz fala inicialmente em "pessimismo (...) um tanto simplório" d'O Ateneu quando comparado ao mundo "exterior", ainda que seja "imponente pelo impulso arrasador". ${ }^{73}$ Essa conclusão seria suprimida na edição em livro, com o acréscimo do seu conhecido desfecho final: "Violência com pés de barro, sua ferocidade não é

\footnotetext{
${ }^{67}$ Ibidem, p. 9.

${ }^{68}$ A partir do seu conceito de "formação supressiva", José Antonio Pasta Jr. reconhece que "é certo que o Grande sertão passa pela mediação do Brasil, mas é igualmente certo que, nele, a mediação é a imediatidade". Para o estudo desse "regime do limite", especificando a sua estrutura de recepção, cf. "O romance de Rosa: temas do Grande Sertão e do Brasil". In: Novos Estudos Cebrap, n. 55, nov. 1999, p. 70. Ver ainda Corpas, Danielle. "O jagunço somos nós: visões do Brasil na crítica de Grande Sertão: Veredas". Campinas, SP: Mercado de Letras, 2015. A citação está em “Grande-Sertão e Dr. Faustus" (Parte II), op. cit., p. 9.

69 “O Atheneu e o naturalismo”. In: Suplemento Literário, 10 set. 1960, p. 40.

${ }^{70}$ Ibidem, p. 40.

${ }^{71}$ Ibidem, p. 40 (grifo meu).

${ }^{72}$ Ibidem, p. 40.

${ }^{73}$ Ibidem, p. 40.
} 
distância". ${ }^{74}$ Assim, tentava-se marcar mais nitidamente a diferença estrutural da obra em relação aos parâmetros do realismo europeu. Por ora, essa percepção de uma "ultrapassagem" local da "impessoalidade da função narrativa" serviria à crítica, mais geral, de certa dissolução da "estrutura específica" dos objetos na narrativa de Pompeia, a partir da qual se multiplicariam "polaridades". 75

\section{Círculo pré-dialético}

A noção moderna de Bildung que o primeiro Schwarz via consumada em Abdias consolida-se, como ideia reguladora, em "O psicologismo na poética de Mário de Andrade", o seu último texto "brasileiro" antes do golpe de 1964. O seu objetivo é demonstrar que a teorização poética de Mário de Andrade, que seria fundada na busca regressiva de uma "verdade psicológica" como critério de valor, encontra-se fora da "experiência propriamente estética". ${ }^{76}$ Para isso, ele situa o trabalho conceitual do modernista sob o signo de uma décalage. O ensaio parte do descompasso entre o momento "orgânico" da cultura burguesa e o desvio "psicologista" local, que relutaria em assimilar o "luzir sensível da ideia, (...) a camada sensível tornada significativa". ${ }^{77}$ Embora o ponto de vista crítico esteja integrado aqui pelo esquema formativo - de modo mais autossustentado que os ensaios anteriores -, a argumentação schwarziana projeta, de fato, um "excesso de intenção sobre a coisa", retomando os termos de Adorno. ${ }^{78} \mathrm{O}$ seu andamento dedutivo sugere, por vezes, um avant-propos metodológico, que contém em parte o movimento ensaístico. Contudo, é importante destacar que Schwarz afere um campo real de problemas, relacionado - entre outros aspectos - a um processo de diferenciação social precário. Considerando as oposições incessantes entre as imagens marioandradinas, o crítico volta-se indiretamente a constrangimentos objetivos ao possível trânsito mediado entre lírica e sociedade no

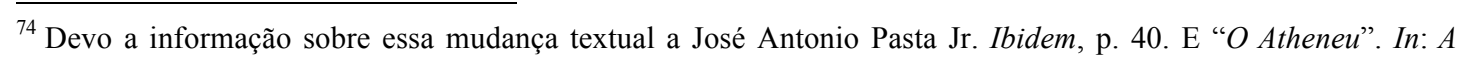
Sereia e o desconfiado, op. cit., p. 30. Para a análise desse romance, ver Pasta Jr., "Pompéia: a metafísica ruinosa d'O Ateneu." 401 f. Tese (Doutorado em Literatura Brasileira) - USP, 1992.

75 “O Atheneu e o naturalismo”. In: Suplemento Literário, op. cit., p. 40.

76 “O psicologismo na poética de Mário de Andrade”. In: idem, 20 mai. 1961, p. 44.

${ }^{77}$ Ibidem, p. 44.

${ }^{78}$ Adorno, "O ensaio como forma”. In: Notas de literatura I. São Paulo: Duas Cidades; Ed. 34, 2003, p. 27 e 36.
} 
país. Nesse caso, o seu limite teórico não se encontra numa suposta "rigidez" de certa dimensão prescritiva da "formação", que foi alvo da crítica. ${ }^{79} \mathrm{O}$ aspecto principal é que, nesse momento, apenas começa a se adensar - em termos de consistência teórica - a possibilidade de compreender o específico da dialética entre forma literária e processo social no Brasil (e os próprios esquemas de análise marxista passam a entrar em contato mais detido com as formas locais de dominação). ${ }^{80}$ Assim, ainda escapam ao crítico cruzamentos decisivos entre o destino pessoal do poeta e o destino do país, ${ }^{81}$ que, entretanto, não deixam de ser a matéria implícita do seu ensaio.

O retrato desse impasse encontra-se na sua formulação parcial do problema: haveria uma espécie de "círculo pré-dialético" na poética de Mário de Andrade. Como dito anteriormente, Schwarz argumenta que a "prisão de noções" absolutas de Mário é incompatível com a síntese estética entre a camada material sensível e o significado. Nesse sentido, ele se propõe a investigar uma série de "polaridades irredutíveis" no seu itinerário teórico. Essa poética "metafisicamente rasgada" teria se desdobrado em dualidades conceituais obsessivas, como "lirismo-técnica, subconsciente-consciente, indivíduo-sociedade, ser-parecer". ${ }^{82}$ A antinomia imagética renascente, sem superação, teria travado a relação dialética entre o dado subjetivo e a significação social mais ampla. Na visão de Schwarz, a sua tarefa crítica seria desvelar os supostos termos falsos que fundamentam essa teorização, por ela "nunca partir da experiência estética como de um dado originário". ${ }^{83}$ Para isso, ele mantém como princípio regulador certo modo consistente de aparecer da "ideia", que supõe a resistência própria de um meio expressivo, respondendo, por sua vez, à virtualidade específica do seu objeto. ${ }^{84}$

\footnotetext{
${ }^{79}$ Louzada Filho critica a "dicção estática" de relatório científico desse ensaio. Numa variação desse problema, Leandro Pasini identifica aqui uma demanda fora de lugar do crítico, que gostaria de ver em Mário um "Lukács ou um Croce brasileiro" e, na prática, teria mostrado um "autor secundário, artista medíocre e mau teórico". Para ele, teria faltado "cautela e paciência" a Schwarz. Louzada Filho, O. C. "Texto e seu enfoque". In: Suplemento Literário, 6 nov. 1965, p. 40. E Pasini, Leandro. A apreensão do desconcerto: subjetividade e nação na poesia de Mário de Andrade. 270 f. Tese (Doutorado em Teoria Literária e Literatura Comparada) - USP, 2011, p. 32. ${ }^{80}$ Schwarz volta a discutir recentemente esse aspecto em "Sobre a leitura de Marx no Brasil”. In: Nós que
amávamos tanto O Capital: leituras de Marx no Brasil. São Paulo: Boitempo, 2017, p. 24.

${ }^{81}$ Cf. Souza, Gilda de Mello e. O tupi e o alaúde. São Paulo: Duas Cidades/Ed. 34, 2003, pp. 53-5.

82 "O psicologismo na poética de Mário de Andrade", op. cit., p. 44.

${ }^{83}$ Ibidem, p. 44.

${ }^{84}$ Como explica Anatol Rosenfeld, o conceito hegeliano de "ideia", enquanto síntese dirigida à totalidade, "não deve ser entendido apenas no seu sentido metafisico, mas abrange todo o mundo imaginário e as próprias
} 
Segundo Schwarz, o primeiro Mário de Andrade vincula imediatamente o belo ao inconsciente lírico. O exemplo dado por ele é o "Prefácio interessantíssimo" (1922), quando o modernismo de combate "lança-se ao extremo oposto" do formalismo oco parnasiano. A linguagem teria se tornado, assim, "simples anotadora de estados líricos", numa zona de indistinção entre poesia e psicologia. Defendendo a tese manifesta de que isso seria uma obscura "instrumentalização" subjetivista na experiência poética, porém mostrando ao longo da sua análise aspectos de uma lógica estético-social mais ampla, ${ }^{85}$ Schwarz acusa aqui um reiterado "hiato entre significado e linguagem". Esse prolongamento das injunções subjetivas no mundo exterior resultaria na "exigência de viver o poema em lugar de escrevê-lo". ${ }^{86} \mathrm{E}$, sob essas "transferências energéticas", a atividade poética perderia o "papel criador, pois o seu objetivo estaria no que a vida já gravou em nós, e não no universo por fazer, que é imaginário", segundo os seus termos. ${ }^{87}$

O objetivo do crítico é combater a ideia de que a exteriorização do sujeito no meio social implique, necessariamente, em "morte e perda". E, nesse sentido, o "momento anti-individualista" de Mário, que teria coexistido simetricamente com o espontaneísmo anterior, também não lhe parece promissor. É o caso do posfácio escrito em 1924 para a Escrava que não é Isaura (1922) e do ensaio "Do cabotinismo" (1939). Nesses textos, segundo Schwarz, a técnica seria valorizada como força disciplinadora do inconsciente, vinculando-se à construção artística socialmente útil, sob o horizonte da proposição nacionalista. Ao naturalizar a feição socializadora da técnica e o caráter destrutivo do inconsciente - que estão fundados numa contingência histórica -, a nova posição de Mário projetaria apenas o "inverso" da virulência lírica, segundo o crítico. Essa, por sua vez, permaneceria ainda como essência profunda. E a relação de Mário com os seus objetos segue, assim, escorada

estruturas, tensões, harmonias e relações dinâmicas que aparecem através da camada sensível". Já na conceituação de Lukács, a imagem simbólica explicita justamente a "ideia a partir do fenômeno ou da aparência", cumprindo assim a "exigência goethiana de uma 'suave empiria', que descobre na realidade mesma o universal ou geral e, transformando-o em particularidade, leve-o à intuição como peculiaridade sensível e manifesta dos próprios objetos". Cf. Rosenfeld, Estrutura e problemas da obra literária. São Paulo: Perspectiva, 1976, p. 16. E Lukács, “Alegoria y símbolo". In: Estética. Barcelona/México, D.F.: Grijalbo, 1967, vol. 4, p. 427.

\footnotetext{
${ }^{85}$ A partir de outro ponto de vista, João Luiz Lafetá vê nesse ensaio apenas um movimento de "simplificação" e de "distorção" da obra de Mário de Andrade, na qual, por sua vez, teria vigência a plena "complementaridade das categorias estética e psicológica”. Lafetá, 1930: a crítica e o modernismo. São Paulo: Duas Cidades/Ed. 34, 2000, pp. 167-175.

86 “O psicologismo na poética de Mário de Andrade”, op. cit., p. 44.

${ }^{87}$ Ibidem, p. 44.
} 
em formas gerais. Desse modo, de acordo com Schwarz, a "técnica não faz mais que vestir as emoções", negando-as em sua particularidade. ${ }^{88}$ Assim, a superioridade absoluta da técnica e consciência coincidem aqui no seu contrário.

\begin{abstract}
Não se trata de negar simplesmente a primeira posição subjetivista. O quadro permanece o mesmo, é necessária uma fonte de energia, a subconsciência, que se exterioriza materialmente num medium social. O que se modificou foi a valoração, que antes emanava da primeira esfera, e agora nasce da segunda. As duas, contudo, verdade psicológica ou proposição social, pretendem fundar o valor estético em lugar de realizarem-se através dele. ${ }^{89}$
\end{abstract}

Nessa oposição estanque entre lirismo e técnica, em que falta a "reciprocidade de perspectivas", Schwarz identifica o hiatus irracionalis. No caso de Mário, trata-se de um nó "metafísico" entre a poesia e a "sinceridade para o ser", ${ }^{90}$ que registraria a negação da "História" e da sua disposição realista. O suposto fermento "irracional" na obra de Mário, relativamente desvinculado das suas determinações históricas, leva o crítico a afirmar que a poesia "não tem lugar" no pensamento do modernista. Ao mesmo tempo, as próprias metáforas schwarzianas sinalizam bem o caráter agônico e aporético do corpo a corpo entre Mário e a sua matéria social. Para o crítico, a "sua reflexão (a de Mário de Andrade) habita como que um poço de paredes lisas, sem saída natural, no qual circula e do qual somente por um salto poderia escapar". ${ }^{91}$ De fato, num contexto periférico, o impulso vanguardista foi praticamente impelido para um projeto de intervenção cultural e social, com sentido civilizatório e nacional, mais do que propriamente "estético". ${ }^{92}$ Dado esse imbróglio objetivo, a partir do qual se deriva um conjunto de contradições - que seriam tratadas posteriormente pela obra de Schwarz -, o jovem crítico faz uma sugestão quase singela ao seu predecessor

\footnotetext{
88 “O psicologismo na poética de Mário de Andrade” (Parte II). In: idem, 27 mai. 1961, p. 42.

89 “O psicologismo na poética de Mário de Andrade”, op. cit., p. 44.

${ }^{90}$ Para a questão da exigência da "sinceridade" na obra de Mário, enquanto consciência aguda e problemática da separação do espírito coletivo que a determina, cf. Rosenfeld, Anatol. "Mário e o cabotinismo". In: Texto/Contexto. São Paulo: Perspectiva, 1978, p. 187.

91 “O psicologismo na poética de Mário de Andrade”, op. cit., p. 44.

${ }^{92}$ Como mostra, afinal, a obra de Mário de Andrade e a sua busca incessante para "tradicionalizar" o passado (incluindo a valorização dos românticos), de modo a erigir uma cultura que traga a ideia contraditória de uma nação integrada. Schwarz aprofundaria a investigação do lugar social do ponto de vista modernista em "A carroça, o bonde e o poeta modernista" (1983), "Nacional por subtração" (1986) e em alguns trechos de "Outra Capitu" (1997), que talvez seja a culminação das suas posições sobre o tema. Cf. "Outra Capitu". In: Duas meninas. São Paulo: Companhia das Letras, 1997, p. 109, 116, 129 e 137-44.
} 
modernista: "Fosse Mário de Andrade menos psicologista e mais afeiçoado à imaginação, não associaria tanto valor à 'experiência imediatamente vivida' em detrimento da evocação fantasiosa". ${ }^{93}$

Nos termos do próprio ensaio, a questão em aberto se formula do seguinte modo: por quê na poética de Mário "torna-se necessário violentar a natureza (...) da linguagem"? ${ }^{94}$ Embora não se defina aqui os motivos da resistência difusa desse material - certa "irredutibilidade" do objeto ao trabalho de configuração estética, que teria gerado um sentimento de "inadequação completa" da síntese simbólica -, Schwarz vê na "fase integralmente política" de Mário, ${ }^{95}$ em particular na sua célebre "Elegia de Abril” (1941), o esboço de uma possível superação das oposições binárias. É quando o autor modernista opera a partir da ideia de uma "potência moralizadora da técnica" pessoal, na qual a pesquisa e a invenção de uma disposição lírica particular teria atinado com uma técnica capaz de realizá-la no "plano do significado geral". A sondagem rigorosa na sua própria subjetividade, aliada ao domínio dos seus instrumentos poéticos, levariam Mário a defrontar-se dialeticamente com as contradições sociais, enfim universalizando-se. Dominando a violência mútua entre a imagem e o conceito, ele reconhece a possibilidade de "pensar filosoficamente a obra de arte" - nos termos de Schwarz -, escapando da oscilação entre uma abordagem que “corrige o objeto" dado e outra que se rege por um "ideal” externo à sua matéria.

Conforme visto, Schwarz aponta uma série de dificuldades para o reconhecimento da autonomia do objeto na teoria de Mário de Andrade, que não conseguiria fundar o seu "significado objetivo na relação com a totalidade de que é parte". ${ }^{96}$ Para isso, ele parte da crítica à relação "instrumental” entre técnica e lirismo, deixando vir a furo nos escritos de Mário uma dinâmica específica de polaridades “irredutíveis", que é subsumida à noção de "círculo pré-dialético". Esse conceito supõe em si um sentimento diferencial e a sua progressão recuperadora. Ou seja, a defasagem em questão - ou o obstáculo "psicologista", nos termos do crítico -

\footnotetext{
${ }^{93}$ Embora Schwarz reconheça, desde a abertura do seu ensaio, que "foi a contragosto e premido pelas carências do meio que (Mário) se dispôs a suprir nossa fome de poéticas". "O psicologismo na poética de Mário de Andrade", op. cit., p. 44.

${ }^{94}$ Ibidem, p. 44.

${ }^{95}$ A expressão é de Mário de Andrade. Cf. o seu "O movimento modernista". In: Aspectos da literatura brasileira. São Paulo: Martins, 1974, p. 242.

96 “O psicologismo na poética de Mário de Andrade” (Parte II), op. cit., p. 42.
} 
encaminha-se para ser emparelhada à dimensão de continuidade e de consequência social própria à moderna tradição europeia. E esse vínculo mais orgânico entre a vida mental e a experiência sócio-histórica aparece, então, como referência estética a ser conquistada. Delimitando nessas fraturas concretas o seu problema dileto, Schwarz levava a crítica literária marxista, pela primeira vez no Brasil, "a dar um passo além da mera alegação de princípios". ${ }^{97}$ Nesse sentido, na década de 1960, enquanto alguns resenhistas ainda repercutiam incômodos em relação à passagem da crítica "impressionista” para a especializada, José Guilherme Merquior reconhecia a questão estratégica ao comentar a estreia de Schwarz. A chegada dessa "orientação participante" na crítica estética brasileira, com rigor conceitual e inspiração em Marx, coaduna-se com o processo de consolidação local de uma tradição universitária, o que determinaria problemas novos. ${ }^{98}$

\section{Tempo progressista e ruínas alegóricas}

Conforme se tentou acompanhar, nessas primeiras análises do jovem Schwarz sobre obras brasileiras, uma das principais preocupações críticas é definir - sob modos diversos - quais os entraves que impediriam a autonomia significativa do texto no plano simbólico. De maneira recorrente, resta-lhe a impressão de que as personagens locais não se configuram a partir delas mesmas. Em geral, os fatos narrados parecem não participar da sua significação objetiva. Assim, tampouco se impõe internamente a experiência de um processo social determinado. Haveria antes uma proliferação de gestos externos e unilaterais nas narrativas, que se furtam à possibilidade moderna de constituição de obras autodeterminadas. O problema torna-se forma no seu breve conto "Relato", publicado um mês antes do ensaio sobre Mário de Andrade (no qual esse aspecto também é central). ${ }^{99}$ Nessa ficção schwarziana, uma personagem busca

\footnotetext{
${ }^{97}$ Arantes, Paulo. Sentimento da dialética, op. cit., p. 53.

${ }^{98}$ Merquior estreia também em 1965, com a publicação de Razão do poema. Nesse período de constituição dos ordenamentos disciplinares acadêmicos - e, ao mesmo tempo, de relativo trânsito entre essas compartimentações -, Wilson Martins associa o "vocabulário absconso e altamente técnico" de Schwarz aos personagens médicos de Molière. Noutro extremo, lendo Schwarz, Luiz Costa Lima defendia que o "centro de convergência e de avanço" da inteligência brasileira, antes vinculado ao romance de 1930 e aos ensaios de interpretação do Brasil, havia mudado definitivamente para a "atividade crítica", em particular a literária. Merquior, "A crítica de Roberto Schwarz". In: Suplemento Literário, 5 fev. 1966, p. 40. Martins, Wilson. "O relativo do absoluto". In: idem, 29 jan. 1966, p. 40. Lima, Luiz Costa. "Schwarz e a crítica nacional". In: idem, 11 dez. 1965, p. 35.

${ }^{99}$ Schwarz, "Relato”. In: Suplemento Literário, 8 abr. 1961, p. 37 (esse texto está transcrito em “Anexos”).
} 
se separar do seu autor. Por meio dessa "re-cisão" insólita, o objeto assume parcialmente o ponto de vista narrativo, esboçando um autoexame da sua condição. Contudo, a tentativa de fundar em si o valor de ação da linguagem, enquanto unidade interna de significação, revela-se precária. E a principal fonte de instabilidade, de acordo com a perspectiva do conto, seria a própria vontade do "autor". O escritor em questão cultua no mundo narrado os "mecanismos ininteligíveis", numa irresistível vocação para o inabordável. Mais do que isso, esse tipo social interpõe o tempo todo a sua esfera pessoal no trabalho com os materiais, rompendo-a. Os vínculos diretos e "sentimentais" entre o real e o simbólico não permitem que a personagem se desdobre, fixando-a em gesto retórico. Desse modo, a denominação arbitrária de um juízo de valor atravessa a cena narrativa, que não corresponde ao problema determinado pelo seu objeto. Como resultado, a relação objetiva com o todo é sempre insubsistente: "Venho conseguindo ditar-lhe minhas normas porém não sei dizer quanto isto há de durar", ironiza o narrador schwarziano. ${ }^{100} \mathrm{Na}$ ausência da mediação do significado pela situação, malogra o esforço para tornar sensível a experiência vivida e representar a sua prática, esvaindo-se as chances de uma produção efetiva de conhecimento. A destruição da "autonomia" da personagem, que vira uma espécie de "cadáver ainda vivo", corresponderia ao gozo do autor brasileiro. Segundo o conto, o problema é que o escritor imaginado não suporta a "existência lógica" da sua matéria social. E, dessa maneira, o mundo inteligível configura-se como uma "prévia autópsia”, alegorizando-se. ${ }^{101}$

Para Schwarz, a alegoria moderna supõe exatamente esse esfacelamento da "autonomia do mundo fictício", certa transcendência vazia a partir da qual o texto "deixa de ter o centro em si mesmo, de ser auto-referido", deslocando o "seu sentido na dependência de noções que não elaborou". ${ }^{102} \mathrm{Na}$ permutabilidade alegórica, o crítico vê uma regressão à "consistência absoluta entre vida e palavra", na qual o "tempo e os atos não fazem violência à linguagem". ${ }^{103}$ Ele rejeita a dissociação abstrata e arbitrária entre a "consciência individual" e o "significado prático" da ação, a partir da qual sujeito e objeto seriam desvinculados da sua radicação histórica. Essa

\footnotetext{
${ }^{100}$ Ibidem, p. 37.

${ }^{101}$ Ibidem, p. 37.

${ }^{102}$ Cf. “A estrutura de Chanaan”. In: Suplemento Literário, 14 jan. 1961, p. 42.

103 "Uma barata é uma barata é uma barata". In: A Sereia e o desconfiado, op. cit., p. 60.
} 
linguagem alusiva, que não seria "torcida pela submissão prática ao objeto exterior", congela a objetivação reificada do existente. ${ }^{104} \mathrm{O}$ procedimento alegórico é entendido, então, como "oposto" à mimese realista, tornando as obras artísticas meros sintomas de um mundo que "aliena radicalmente qualquer prática humana que nele se intente", segundo Schwarz. ${ }^{105}$ Sob essa lógica disjuntiva, associada a um suposto padrão prefigurado de equivalências eternas, vigoraria a percepção "fantasmal" da exterioridade, que se interpõe no texto como barreira "plenamente significativa". Esse ponto de vista narrativo, diz Schwarz, apenas ratifica a barbárie imediatamente dada, assimilando as "suas contradições com a violência do auto dilaceramento". ${ }^{106}$

Nesse mundo narrado sem "finalidade prática", no qual a causalidade interna não seria submetida a um nexo forte de sentido, o que se entrevê é a "destruição da temporalidade histórica", desprovida da dimensão de futuro e da sua imanente "força criadora", segundo os termos do crítico. ${ }^{107} \mathrm{~A}$ alegoria é identificada, então, a um tempo fátuo e mecânico, reiterado por um fatalismo "anti-humanista" da obra em relação à sua matéria. No raciocínio de Schwarz, esse modo de configuração atestaria a inaptidão da narrativa para apreender a realidade como processo histórico. Ou seja, faltaria um nexo total que produz e reproduz cada momento parcial, enquanto determinação a ser negada. As obras alegóricas desarticulariam a dialética entre o detalhe e o conjunto objetivo, a interioridade e a exterioridade, enquanto "momentos comunicantes $e$ distintos". ${ }^{108}$ Nesses casos, Schwarz vê a consciência narrativa dissolvida e "unificada pela situação em lugar de unificá-la", sem duração articulada, e que tende à descrição exterior do outro social como uma "imagem genérica de si mesma". ${ }^{109}$ A precedência dessa descontinuidade "irracionalista", nos termos de Schwarz, "desfaz" as determinações sensíveis. E a "História", entendida enquanto temporalidade cumulativa e orientada, volatiliza-se em imagens intercambiáveis.

\footnotetext{
${ }^{104}$ Ibidem, p. 71.

${ }^{105}$ Ibidem, p. 60.

${ }^{106}$ Ibidem, p. 72.

${ }^{107}$ Ibidem, p. 62.

${ }^{108}$ Ibidem, p. 69 (grifo do autor).

${ }^{109}$ Ibidem, p. 64 e 67 (grifo do autor).
} 
Retomando a formulação de Lukács - que Walter Benjamin, neste ponto, não discordaria -, o alegórico "significa precisamente o não-ser do que representa". 110

Escrevendo sobre Canaã (1902), no qual a alegoria aparece como a figura final de uma ambição realista malograda, Schwarz vê novamente a indistinção perversa entre as esferas do "juízo ficcional”, interno à narrativa, e a do "juízo de realidade”, por meio do qual Graça Aranha tenta enunciar “"verdades” sobre o Brasil e a condição humana". ${ }^{111}$ Divergindo da leitura de Lucia Miguel Pereira, que localiza na obra certa síntese entre o "universal" e o "brasileiro", o crítico expõe a incursão teorizante do autor na sua matéria, numa contaminação recíproca que teria produzido uma "filosofia ficcionalizada" e uma "ficção fillosofante". O seu esquema de leitura opera com a incompatibilidade entre a "dimensão realista", que pede a configuração de um indivíduo particular, e os excursos descritivos-conceituais do autor, que vão da "cosmologia à determinação essencial do homem". ${ }^{112}$ Para ele, essa descontinuidade sufoca as contradições reais da sua matéria, e o anseio de discutir o país não "flui" da própria experiência das personagens. Esvaziada, a trama perde a sua "força de evidência". ${ }^{113} \mathrm{Na}$ passagem "anti-humana" da imagem singular para o conceito, a narrativa dissolve a sua eventual particularidade em oposições gerais, resultando num abismo entre a conformação estética do aparecer sensível e certa tentativa de regulação pseudocientífica do objeto. Desse modo, desequilibra-se a unidade formal do livro, constituindo-se dessemelhanças alegóricas. Para Schwarz, o limite estético de Canaã encontra-se nesse "estrabismo" de Graça Aranha, dividido entre a representação da realidade brasileira e o influxo externo do vitalismo conservador alemão. Segundo ele, excluem-se mutuamente nessa forma literária a objetivação moderna do romance e o constructo teórico de uma obra de brasiliana. O autor "não

\footnotetext{
${ }^{110}$ Lukács, "Alegoria y símbolo". In: Estética, op. cit., p. 464. Cf. ainda Benjamin, Walter. Origem do drama barroco alemão. São Paulo: Brasiliense, 1984.

111 “A estrutura de Chanaan”. In: Suplemento Literário, op. cit., p. 42.

${ }^{112}$ Ibidem, p. 42.

${ }^{113}$ Em 1961, na sua primeira referência machadiana explícita, diz Schwarz: "Seria possível contra-argumentar com Machado de Assis, cujos romances são continuamente interrompidos pelo dito sentencioso, alheio à trama central. Em Machado, entretanto, a esfera das considerações do autor é ela mesma esteticamente organizada, enriquece as personagens em lugar de anulá-las”. Ibidem, p. 42.
} 
entrevê a possiblidade de ser um através do outro", afirma Schwarz. ${ }^{114}$ Em suma, Graça Aranha teria se fixado nessa escolha indecidível.

$\mathrm{Na}$ sua relação com a alegoria, Schwarz distingue uma linguagem que "mediatiza homens e coisas", ligada ao trabalho com "significações reais" e mutáveis, e o seu suposto contrário, que almeja “objetivar o próprio processo de mediação", por onde se infiltrariam generalidades, segundo ele. Não se entrevê a possiblidade, e a necessidade histórica do seu material, de configurar um plano através do outro. $\mathrm{O}$ principal exemplo disso é a sua primeira leitura de Kafka. Enquanto paradigma da fragmentação alegórica moderna, A Metamorfose (1915) aparece como manifestação opaca do niilismo "irracionalista", da auto-aniquilação que "eterniza a desgraça que acusou". ${ }^{115}$ Para Schwarz, o "antirrealismo" do autor tcheco expressaria a "pura figuração do desespero". O seu mal-estar no mundo teria se cristalizado numa ideia absoluta e irremediável, baseada na percepção exterior da existência como mera agitação aleatória. Desse modo, os famosos gestos perpetuados em Kafka são interpretados como figuração perplexa dos problemas "últimos" do genericamente humano, e não enquanto instantes históricos "congelados", que interessam auscultar. ${ }^{116}$ Ao hipostasiar in abstracto o "tom de especulação teológica" nessa obra, a crítica de Schwarz se alinha involuntariamente com o seu contrário. Ou seja, com os leitores metafísicos de Kafka, denominados por ele como os "fenomenólogos da danação humana". ${ }^{117}$ Ao mesmo tempo, como visto até aqui, as suas reflexões sobre as possibilidades contemporâneas do realismo também tentam responder, desde os impasses de uma literatura nacional periférica, às variadas tendências ontológicas então em voga, inspiradas na filosofia de Martin Heidegger. Esse zeitgeist "antifundacionalista", sob o pretexto de refutar a metafisica, colocava em suspeita as

\footnotetext{
114 Ibidem, p. 42.

115 "Uma barata é uma barata é uma barata”. In: A Sereia e o desconfiado, op. cit., p. 72.

${ }^{116}$ Para Adorno, a fortuna crítica de Kafka confundiu a tese "abstrata" da sua obra, a "obscuridade da existência", com o seu "teor". Assim, enquanto ilustração da ontologia, Kafka foi "enquadrado em uma corrente de pensamento estabelecida", que o rebaixa a "escritório de informações sobre a condição eterna ou atual do homem". Segundo Adorno, ao contrário, em Kafka o "nome da história" não é pronunciado porque "aquilo que seria história, o outro, ainda não se iniciou". Daí os seus cenários obsoletos, os traços extremados e as relações sociais aparentemente estáticas. O "tempo absolutamente subjetivo" ressoaria o princípio da "alienação inexorável", alcançando uma sóbria objetividade que se expressa através da própria reificação, o que Adorno chama de "épica tortuosa”. Em 1966, a interpretação de Schwarz sobre o sentido do obsoleto na obra de Kafka se altera radicalmente, figurando-se ali um contraponto ao caráter parasitário da sociedade burguesa. Cf. "Anotações sobre Kafka”. In: Prismas - Crítica cultural e sociedade. São Paulo: Ática, 1998, p. 239, 241, 254 e 259-60. E Schwarz, “A tribulação do pai de família”. In: Suplemento Literário, 12 mar. 1966, p. 46.

${ }^{117}$ Cf. "Uma barata é uma barata é uma barata". In: A Sereia e o desconfiado, op. cit., p. 72.
} 
noções de verdade, sentido e conhecimento nas obras artísticas. Para o jovem Schwarz, tais postulados desembocam num discurso ideológico que se furta ao teor objetivante próprio à crítica, que, por definição, supõe a exigência moderna de fundamentação e justificação argumentativa.

No entanto, talvez seja na relação com o romance russo que o Schwarz pré1964 encontre o seu mais elevado limite crítico. Trabalhando com a configuração de uma matéria social marcada pela coexistência entre capitalismo e servidão, os seus ensaios sobre Dostoiévski atestam um senso agudo para as ambivalências periféricas. Discutindo o funcionamento enviesado do ideário burguês em território russo ${ }^{118}$ - e a despeito de não se reconhecer aqui a homologia brasileira do seu assunto -, Schwarz apreende com precisão no romance dostoiévskiano certo mecanismo social de "desmoralização das ideias", a partir do qual o pensamento parece não ter “compromisso algum com a verdade". ${ }^{119}$ Nos seus termos, as ideias aqui são antes “justificação" estratégica dos atos do que "representação fiel deles". ${ }^{120}$ Em outros termos, a modernização ocidental já aparece como imposição na Rússia. Na duplicidade de critérios que sustenta esse romance, o parâmetro "utilitário e competitivo" mostra-se "incompatível com o fluxo espontâneo das relações humanas", segundo Schwarz. Ao mesmo tempo, as "duas normas coexistem, de modo que tanto a lealdade pessoal quanto o oportunismo parecem gozar de uma certa justificação moral", nas palavras do crítico. ${ }^{121} \mathrm{O}$ exemplo dado por ele é a figura do narrador Stepan Trofimovitch n'Os Demônios (1872) - tratado pelo romancista sob a chave do ridículo -, cujo brilho intelectual liga-se à esfera pessoal, e não às capacidades práticas. Não se trata apenas da ausência da prova real dos atos. Numa situação de dependência em relação à sua benfeitora Varvara Petrovna, e almejando o ideal inescapável do sujeito autônomo ocidental, Trofimovitch lidaria o tempo todo com o "não-ser do que nunca foi", sendo a própria "aparência sem nada atrás", de acordo com Schwarz. Assim, rifada a "dialética interior", o seu desenvolvimento

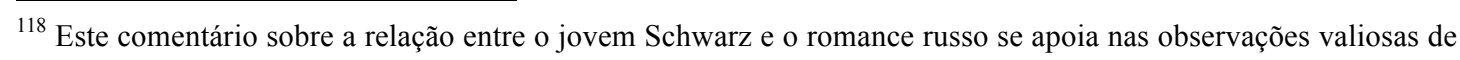
Arantes, Paulo. Sentimento da dialética, op. cit., pp. 103-5.

119 "Para a fisionomia de Os Demônios". In: A Sereia e o desconfiado, op. cit., p. 76.

120 "O mano capeta do liberalismo (O Sósia)". In: idem, p. 95.

${ }^{121}$ Ibidem, p. 87.
} 
“acidental” oscila entre a compensação imaginária e a adesão ao existente. ${ }^{122}$ E essa curva dramática teria a "tempestade sempre no horizonte", pois qualquer "conflito com a benfeitora, e tremem-lhe não só os subsídios, como também a imagem que tem de si, a própria identidade", nas palavras de Schwarz. ${ }^{123}$

Em meio a essas descrições certeiras do romance russo, o crítico acusa em Dostoiévski a confirmação gozosa e agônica das contradições locais do liberalismo. A assimilação "vacilante" do ideário liberal apareceria, nas suas obras, ora como justificação da "prática oportunista" - enquanto redução da vida social a uma pura relação de poder, alheia às considerações morais - ora como perda completa do senso do real. Ambos os registros, argumenta Schwarz, significam um abandono indevido da perspectiva de "organização do mundo social". Para ele, Dostoiévski teria chancelado a abdicação regressiva da vida humana até a prova do absurdo. ${ }^{124}$ Dada essa suposta renúncia à prática racional, o sentido da purgação dostoiévskiana configura-se como uma paradoxal "humildade utópico-estropiada". Isso porque o escritor russo não teria entendido o "sentido apenas restrito" da aniquilação, que permanece na sua obra como o "último ato". Desse modo, não se poderia reconstituir a "gênese" contraditória da "vida minada". Essa contradição seria apenas descrita, dispondo-se os elementos em tensão, sem que ato algum os "unifique numa sequência de tempo vivido". Nesse "tempo de beco" - segundo a boa definição de Schwarz -, diferentemente da estratégia habitual do romance no século 19, o "todo social não é visto na perspectiva do esforço individual, que quer modificá-lo, mas é o propósito individual que é julgado a partir do todo". ${ }^{125}$ Para o crítico, trata-se de uma prova da experiência "totalitária" dessa prosa, num "padrão próximo ao fascismo". ${ }^{126}$ Contudo - e esta é a diferença decisiva em relação aos seus ensaios anteriores -, Schwarz nota que a lógica de autodestruição das ideias progressistas transcorre em meio à ausência

\footnotetext{
${ }^{122}$ Segundo Schwarz, "entre as existências ideal e atual não há ponte; são concebidas como de natureza diversa. A ideia de começar por uma e chegar à outra, de ligar as duas através dos atos, parece impraticável”. Ibidem, p. 83.

123 "Para a fisionomia de Os Demônios", op. cit., p. 75.

${ }^{124}$ Ibidem, p. 78.

125 "O mano capeta do liberalismo (O Sósia)", op. cit., p. 95.

${ }^{126}$ Nesse aspecto, como mostra Paulo Arantes, Schwarz lê Dostoiévski "à maneira pela qual Lukács julgara a funesta evolução de conjunto da ideologia alemã, de Schelling a Heidegger, onde apologia da idiossincrasia nacional e ruína da razão andavam juntas". Noutro sentido, Bento Prado Jr. reclama que Schwarz "hegelianiza" Dostoiévski ao ver n'Os Demônios uma mera incapacidade para abandonar a "prisão do finito". Ver Prado Jr., "A Sereia Desmistificada". In: Teoria e Prática. São Paulo, 1968, n. 2, pp. 70-1. E Arantes, Sentimento da dialética, op. cit., p. 104. A citação encontra-se em "Para a fisionomia de Os Demônios", op. cit., p. 79.
} 
objetiva das classes subalternas, que não têm acesso ao resultados da civilização contemporânea. Em razão dessa presença ausente, as ideias seriam "realmente veleidade e engano". ${ }^{127}$ Daí a multiplicação local do sujeito que "não sobrevive ao encontro literal consigo mesmo". ${ }^{128}$ A partir da notação desse desarranjo prático entre os ideais e os seus destinatários, a não convergência entre conhecimento e interesse, as catástrofes dostoiévskianas e o seu "gosto de terror sagrado" ganham uma especificação própria. E não se explicam mais por meio do vezo psicológico das personagens ou por algum estatuto metafisico, como reconhece Schwarz.

\footnotetext{
${ }^{127}$ Ver todo o parágrafo central que contém essa afirmação. "Para a fisionomia de Os Demônios", op. cit., p. 79.

128 "O mano capeta do liberalismo (O Sósia)", op. cit., p. 81.
} 


\section{Capítulo II}

\section{Vozes da imediatidade prática no Brasil pré-1964}

\section{Primado da política}

De agosto de 1961 a maio de 1963, Roberto Schwarz deixa o Brasil para cursar o mestrado na Universidade de Yale (EUA). Nesse período, ele diz ter perdido "completamente o contato" com a situação política nacional, que iria sintonizar com a hipótese difusa da revolução. ${ }^{129} \mathrm{O}$ autor viaja no mesmo dia em que o ex-presidente Jânio Quadros renuncia ao mandato. "Ele renunciou enquanto eu estava no ar. Saí do Brasil sem saber. Quando cheguei lá, todos me perguntavam o que tinha acontecido. Eu não tinha a menor ideia", afirma. ${ }^{130}$ No exterior, Schwarz não recebe notícias sobre o acirramento da luta popular, que assumia dimensão política inédita no país. A sua temporada norte-americana é marcada por uma circunscrição acadêmica relativamente estrita, num sentido diverso da rua Maria Antônia - "provinciana, séria, simpaticamente pequeno-burguesa" -, ${ }^{131}$ que, desde um viés antioligárquico, formava "núcleos de vanguarda bons sob qualquer aspecto", nos seus termos. ${ }^{132}$ Na Faculdade de Filosofia, o transplante das técnicas de explication de texte servia ao momento

\footnotetext{
${ }^{129}$ Nos EUA, Schwarz até providencia uma assinatura d'O Estado de S. Paulo. Todo mês, ele recebia em casa um enorme saco de estopa, com cerca de trinta edições do jornal. O plano, porém, logo seria abandonado. "O primeiro saco eu abri. Tentei ler. Mas depois falei: 'Não vou ler 30 dias seguidos de Estadão aqui'. Então, já largava o saco e nem abria. (...) Perdi completamente o contato (com o Brasil)", diz. Nas horas vagas, ele dedica-se à leitura dos romances e contos de Machado de Assis, trazidos do Brasil. As declarações foram feitas numa entrevista ao autor, realizada em São Paulo, no dia 26 de março de 2018.

${ }^{130}$ Cf. "A dialética envenenada de Roberto Schwarz" (entrevista a Fernando de Barros e Silva). In: Folha de S. Paulo, 01 jun. 1997, p. 66.

131 "Um seminário de Marx". In: Sequências brasileiras, op. cit., p. 89.

${ }^{132}$ Entrevista ao autor, op. cit.
} 
tardio de iniciação e diferenciação acadêmica, a partir do qual se articulavam certo marxismo universitário e um novo ciclo explicativo do país. Em Yale, a situação era outra. Sob o domínio do new criticism, havia se esgotado mesmo certa presença polêmica e inovadora implicada na defesa do close reading, que se debatia contra as distorções "externas" do determinismo histórico-social e da crítica biográfica, correntes atuantes no meio literário anglo-americano (mas que já cediam terreno). Desse modo, Schwarz conhece new critics como Cleanth Brooks e William Wimsatt, além de René Wellek (teórico do grupo), na condição de "glórias nacionais" - sem contraditores à vista -, e ministrando cursos que, para ele, tinham pouco interesse. ${ }^{133}$

A hegemonia ideológica do new criticism, com a rotinização do seu ofício autotélico de descrição de enunciados poéticos - refratário à funcionalidade moderna da linguagem -, aparecia a Schwarz como parte da dinâmica produtiva de uma grande universidade conservadora. Em Yale, o ritmo frenético de publicação de papers, com "vinte páginas corretas quase sem ideias", ${ }^{134}$ coexistia sem arestas com o macarthismo presente no dia a dia estadunidense. Schwarz chega a comparar essa rotina de trabalho a uma sessão de "choques elétricos". "Era duro e eu senti, na época, como uma brutalização intolerável, que neurotiza qualquer um. (...) Saí do Brasil achando que era um intelectual e estava fazendo papers a toque de caixa", afirma. ${ }^{135}$ Um dos seus poucos focos de interesse seriam as aulas sobre literatura norteamericana ministradas por Charles Feidelson Jr., vinculado aos American Studies. Segundo ele, Feidelson empenhava-se em "assinalar e interpretar as singularidades da tradição literária e reflexiva local, vista do ângulo de sua precariedade em comparação com a Europa", ${ }^{136}$ o que lhe remetia aos trabalhos de Candido. Contudo, talvez mais

\footnotetext{
${ }^{133}$ Numa carta enviada a Antonio Candido em 1961, Schwarz afirma: "Em São Paulo, eu não tomaria um ônibus para assistir essas aulas. Mas, para cá, tomei um avião". Candido, por sua vez, temia o risco de fechamento teórico precoce do crítico de 23 anos. Antes da ida à Yale, Schwarz havia enfrentado dificuldades burocráticas para a concessão de uma bolsa de estudos com Adorno na Alemanha, que era a sua primeira opção. Cf. Almeida, Jorge de. "Pressupostos, salvo engano, dos pressupostos, salvo engano". In: Um crítico na periferia do capitalismo, op. cit., pp. 45-6. As cartas foram referidas em entrevista ao autor, op. cit.

134 "Roberto Schwarz" (entrevista a Ismail Xavier, Ângela Alonso, Flávio Moura e Henri Gervaiseau). In: Moura, Flávio; Montero, Paula (orgs.). Retrato de grupo: 40 anos do Cebrap. São Paulo: Cosac Naify, 2009, p. 236.

${ }^{135}$ Os seus trabalhos de aproveitamento de curso em Yale, que analisam romances estrangeiros, não serão discutidos de modo pormenorizado nesta tese. Até onde se pôde verificar, inexistem estudos que considerem essa produção crítica no seu conjunto. Para a relação completa dos textos, publicados n'A Sereia e o desconfiado (1965), ver “Anexos”. A citação encontra-se em “A dialética envenenada de Roberto Schwarz”, op. cit., p. 66.

${ }^{136}$ A disciplina "American Literature", acompanhada por Schwarz entre 1962 e 1963, é a única atividade didática de Yale mencionada no seu memorial. Cf. "Percurso". In: Memorial Unicamp (apresentado por ocasião do concurso para professor titular no Instituto de Estudos da Linguagem). São Paulo, 1990, p. 2 (datilografado). O material está disponível para consulta no Arquivo Central da Unicamp (AC/SIARQ).
} 
significativa do que a interlocução com alguma linha de pesquisa específica, o que the "valeu muito" nos dois anos em Yale - nas palavras do autor - teria sido reconhecer que "nós não éramos tão 'duros' como supúnhamos". Para Schwarz, "era melhor o nosso microclima do Seminário d'O Capital, do Candido, do Anatol". ${ }^{137}$ Certa vez, o crítico declarou mesmo que o seu "marxismo se consolidou lá, de birra". ${ }^{138}$ Seja como for, Schwarz não participa de atividades políticas de oposição nos EUA. "Lá também deveria ter um microclima mais de vanguarda, mas eu não conheci”, diz ele. ${ }^{139}$

No retorno ao Brasil, não poderia ser mais agudo o contraste entre essa inserção escolar mais confinada, politicamente inócua, e a abertura histórica esboçada pela "Aufklaerung popular" pré-1964. Schwarz discutiria depois essa aclimatação do raciocínio político de esquerda no país, que se manifestava na "fala cotidiana", segundo ele. ${ }^{140}$ Nas suas palavras, que elaboram a surpresa inicial, "as opções mundiais aparecem de dez em dez linhas e a propósito de tudo, às vezes de maneira desastrada, às vezes muito engraçada", e em geral "erguendo as questões à sua consequência histórica, ou a uma caricatura dela". ${ }^{141}$ Em maio de 1963, porém, a sua primeira reação é de estupor. Ainda durante o voo de volta, ele se espanta ao ler os ataques contra os Estados Unidos feitos por Otto Maria Carpeaux, que era o principal colunista do Correio da Manhã. Crítico literário de origem católica e conservadora, Carpeaux vinha fustigando as intervenções norte-americanas "com uma violência que me deixou de queixo caído", lembra Schwarz. ${ }^{142}$ A partir do avanço do nacionalismo anti-imperialista, sustentado por vasta mobilização social, mesmo um polígrafo

\footnotetext{
${ }^{137}$ A primeira vez que Schwarz diz ter acompanhado um exercício de close reading foi num seminário sobre Morte em Veneza, conduzido por Anatol Rosenfeld, em 1958. "A gente analisava frase por frase, e o Anatol discutia. (...) Quando eu vi depois o close reading dos americanos, era uma coisa de interesse limitado. (...) $\mathrm{O}$ Anatol mobilizava conhecimentos de toda espécie: sociologia, antropologia, psicologia, psicanálise, filosofia. Ele enfrentava o texto, movimentando tudo o que sabia. Era uma coisa impressionante", afirma. Nesse seminário, diz ele, "o Anatol me pôs isso na cabeça (o interesse pelo close reading), e eu acreditei desde o comecinho". Essa experiência antecede o seu contato sistemático com a crítica de Lukács, Adorno, Benjamin e mesmo Antonio Candido, que teria Schwarz como aluno em seu último curso na área de Sociologia, também em 1958. Antes disso, segundo Schwarz, Candido estava "muito retirado". "Quando parou de publicar os rodapés, ele se fechou em copas para escrever a Formação da literatura brasileira. Então, publicava muito pouco", afirma. Bento Prado Jr. menciona brevemente esse seminário de Rosenfeld em "Retoques a "A sereia desmistificada"'. In: Um crítico na periferia do capitalismo, op. cit., p. 340. Entrevista ao autor, op. cit.

138 “Roberto Schwarz". In: Retrato de grupo, op. cit., p. 236.

${ }^{139}$ Entrevista ao autor, op. cit.

${ }^{140}$ Nos termos de Schwarz, as pessoas estavam "tomando consciência, as conversas e questões se tornando mais inteligentes, e todo o arsenal de lugares-comuns e banalidades sobre o país se dissolvendo", numa "extraordinária clarificação sociológica" do Brasil. Ver "Roberto Schwarz". In: Retrato de grupo, op. cit., pp. 236-7.

141 “Cultura e política, 1964-1969”. In: O pai de família, op. cit., p. 74.

142 “Roberto Schwarz". In: Retrato de grupo, op. cit., p. 236.
} 
consagrado como Carpeaux - sem histórico de militância socialista - parecia abandonar a discussão dita literária. E mostrava-se concernido por um tipo virulento de comentário diretamente político sobre os fatos do dia, interpelados à luz dos embates estratégicos da Guerra Fria. Essa metamorfose lhe oferecia um "primeiro cheirinho do novo clima brasileiro". ${ }^{143}$ Num momento de crise e acirramento das promessas de integração do nacional-desenvolvimentismo, a percepção do tempo social brasileiro se acelera, sugerindo a proximidade histórica de um desfecho socialmente progressista. "A estrutura social indefensável parecia abalada, em via de mudar diante de nossos olhos", afirma Schwarz. ${ }^{144}$

De fato, o crítico enfatiza o que ele entende ser o "primado da política" na vida brasileira pré-1964, ${ }^{145}$ enquanto atividade formativa apta a encaminhar conflitos nacionais e de classe, sob expectativas crescentes de futuro. Em "Cultura e política, 1964-1969", como se sabe, são verificadas as principais pautas que vinham ao proscênio no debate da época (a reforma agrária, o imperialismo, o salário mínimo, o voto do analfabeto), e que teriam traduzido, em escala social inédita, a "experiência

\footnotetext{
${ }^{143}$ A atividade jornalística de Carpeaux começa na Áustria dos anos 1930, quando ele era próximo ao Partido Social Cristão, de orientação nacionalista e conservadora. Na época, a principal liderança do grupo era o chanceler Engelbert Dollfuss, que busca implementar o chamado "austrofascismo", e termina assassinado a tiros por agentes de Hitler, em 1934. Segundo Álvaro Lins, uma das obras de juventude de Carpeaux, chamada A missão europeia da Áustria, era um "livro da predileção" de Dollfuss. Carpeaux adere ao catolicismo em 1932. E chega ao Brasil quando já tinha perto de 40 anos, após a "anexação" da Áustria pela Alemanha. O destino do exílio é definido por meio de tratativas entre o Vaticano e o crítico católico Alceu Amoroso Lima. A partir de 1941, pelas mãos de Álvaro Lins, ele torna-se presença assídua nas páginas do Correio da Manhã e de outros jornais brasileiros. Até o início dos anos 1960, a posição política de Carpeaux se mantém nos limites de um "catolicismo empenhado nos problemas sociais, mas de conotação antes liberal", como define Antonio Candido, para quem o último Carpeaux também parecia "sair (ao menos em intenção) da literatura, onde tinha passado a vida". A sua seção de política internacional, referida por Schwarz, seria cancelada pelos militares em 1966, quando ele fica impedido de assinar matérias no jornal. Após o golpe, Carpeaux exerce a função de mensageiro nas primeiras tentativas de resistência armada à ditadura. É desse contexto o seu artigo "A lição de Canudos, sempre atual", no qual a rebelião dos sertanejos serve para sustentar a tese (ou a convicção ético-política) sobre a vulnerabilidade do Exército brasileiro à tática de guerrilha. "Canudos foi a semente da China Brasileira, da Argélia Brasileira, do Vietcongue Brasileiro", dizia Carpeaux. Em viagens pelo Brasil, dando suporte ao grupo de Leonel Brizola, e posteriormente a outras organizações armadas, Carpeaux decorava longas mensagens secretas, que transmitia pessoalmente a interlocutores. "Era só ele, gago, estrangeiro, indo ao Recife, por exemplo, a propósito de fazer alguma coisa. Chegava lá, ele contava tudo aquilo. (...) Foi uma atividade revolucionária de extrema originalidade, muita utilidade e perigo", afirma Antonio Callado. Para uma amostra desses trabalhos de Carpeaux, autor convertido em totem por uma direita em negação sobre 1964, ver O Brasil no espelho do mundo. Rio de Janeiro: Civilização Brasileira, 1965. E A batalha da América Latina. Rio de Janeiro: Civilização Brasileira, 1965. Para o testemunho de Callado, ver entrevista concedida a Ridenti, Marcelo. Em busca do povo brasileiro. Rio de Janeiro: Record, 2000, pp. 147-8; e também a Chiappini, Ligia. "Alemanha-Brasil: dinâmicas transculturais e ensaios transdisciplinares. Otto Maria Carpeaux, a superação do exílio pela transculturação". In: Revista Antares. Caxias do Sul, jan.-jun. 2011, n. 5, p. 140. Para o artigo de Álvaro Lins, ver "Um novo companheiro". In: Correio da Manhã. Rio de Janeiro, 19 abr. 1941, p. 2. Um perfil do autor encontra-se em Candido, "Dialética apaixonada". In: Recortes. São Paulo: Ouro sobre Azul, 2004, pp. 98-106.
}

\footnotetext{
144 “Roberto Schwarz". In: Retrato de grupo, op. cit., p. 236.

${ }^{145}$ Entrevista ao autor, op. cit.
} 
organizada" dos sindicatos operários e rurais, das entidades estudantis e patronais, e de frações radicais da burguesia. ${ }^{146} \mathrm{~A}$ despeito das turvações ideológicas, discutidas por Schwarz, operava-se a partir da expectativa de uma convergência entre o “desenvolvimento nacional" - lugar de empenho militante e categoria de análise social -, e certa luta cumulativa por direitos (travada, então, sob a hipótese da partilha de bens comuns na passagem da condição colonial à “nação"). E essa luta pré-1964, dizia Schwarz, parecia se estruturar "nos termos que o processo nacional sugeria, de momento a momento, aos principais contendores". ${ }^{147}$ A comunidade imaginada em torno da constituição desse eixo interno - dotado de "dinamismo próprio, longo no tempo, com origens e fins mais ou menos tangíveis", como definiu certa vez o crítico -, ${ }^{148}$ tinha como motor, até certa medida, um processo contraditório de internacionalização da propriedade industrial, que seria consumado de maneira ruinosa pela contrarrevolução preventiva de $1964 .{ }^{149}$

No pré-golpe, porém, o diagnóstico schwarziano sobre as linhas de força que emergiam com certa clareza no plano político - que se formula em "Cultura e política, 1964-1969" - supõe, entre outros aspectos, a ideia de que o processo econômico iria incorporar o conjunto da sociedade nacional à esfera assalariada, inserindo-a na dinâmica abrangente da luta de classes. Acreditava-se, nesse momento, numa centralidade positiva da industrialização, que incluiria e teria sede de trabalho vivo. $\mathrm{Na}$ Faculdade de Filosofia da USP, então em campanha pela construção da respeitabilidade "científica" da dialética, responde-se de modo oblíquo e inventivo às virtualidades integradoras dessa modernização conduzida pela elite. Entre 1962 e 1964, são publicados os primeiros estudos a vincular uma leitura cerrada e metódica de Marx ao dínamo da pesquisa empírica especializada - o que era novidade no país -, buscando-se pensar as formas anômalas de dominação social numa ex-colônia à luz do seu lugar moderno na divisão mundial do trabalho. Sob diferentes modos, essa

\footnotetext{
146 “Cultura e política, 1964-1969”. In: O pai de família, op. cit., p. 83 (grifo do autor).

${ }^{147}$ Ibidem, p. 83.

148 "Fim de século". In: Sequências brasileiras, op. cit., p. 158.

${ }^{149}$ Na síntese do sociólogo Francisco de Oliveira, a "nova forma do desenvolvimento capitalista levada aos limites pela ditadura militar reforçou o centro de decisões interno", mas somente na medida em que "abriu os flancos para o começo de sua extroversão". Ou seja, uma "parte notável do excedente tomava o rumo do exterior para o pagamento da dívida, com o que se caminhou já nos anos 1980 para uma crise da dívida externa que marcou todo o período e tornou quase sem eficácia econômica a redemocratização política". Cf. "Política numa era de indeterminação: opacidade e reencantamento". In: Oliveira, Francisco de; Rizek, Cibele Saliba (orgs.). A era da indeterminação. São Paulo: Boitempo, 2007, p. 20.
} 
perspectiva fundamenta Capitalismo e escravidão no Brasil meridional (1962) e Empresário industrial e desenvolvimento econômico (1964), de Fernando Henrique Cardoso - que puxam a fila de publicações do Seminário Marx -, Homens livres na ordem escravocrata (1964), de Maria Sylvia de Carvalho Franco, e Política e revolução social no Brasil (1965), coletânea escrita no final de 1963 por Octávio Ianni, Francisco Weffort, Paul Singer e Gabriel Cohn.

Ao longo dos anos 1960, Schwarz conta ter "ruminado bastante" Capitalismo e escravidão no Brasil meridional, mas sempre lhe parecia que "faltava algo" para conectar a tese de FHC e os seus próprios estudos sobre o romance brasileiro (e sobre a obra de Machado de Assis, em particular). ${ }^{150} \mathrm{Na}$ mesma medida, o trabalho de Maria Sylvia de Carvalho Franco teria um rendimento posterior no seu ensaísmo. "Provavelmente não assimilei na primeira leitura. O fato é que foi ali por 1970, quando eu estava escrevendo 'As ideias fora do lugar', que ela fez diferença na minha cabeça", afirma. ${ }^{151}$ De imediato, o estudo que o impressiona é Empresário industrial e desenvolvimento econômico. Essa tese de livre-docência de Cardoso, apresentada em novembro de 1963, é uma das primeiras exposições detalhadas sobre a inviabilidade do reformismo dito "populista" no Brasil (que, evidentemente, já era alvo da esquerda crítica ao Partido Comunista). A partir de entrevistas com empresários brasileiros, Cardoso rastreia a possível opção estrutural das camadas dirigentes por uma forma dependente e associada de desenvolvimento econômico, que ele nomeia então como “subcapitalismo". Essa noção, contraposta diretamente à alternativa socialista, referese a uma brecha dinâmica e contraditória - configurada pela economia internacional -, que poderia dar sustentação à iminente desistência histórica da "burguesia nacional", conformada à "condição de sócio menor" do imperialismo e de "guarda avançada da agricultura que muito lentamente se capitaliza", nos termos de Cardoso. ${ }^{152}$ Escrita em polêmica com as formulações hegemônicas do $\mathrm{PCB}$, que se orientavam por uma noção de desenvolvimento e integração social endogenamente propulsionados, a tese desfazia ilusões relacionadas à aliança entre setores empresariais e o operariado

\footnotetext{
150 "Ao vencedor as batatas 30 anos: crítica da cultura e processo social. Entrevista com Roberto Schwarz" (a Lilia Schwarcz e André Botelho). In: Revista Brasileira de Ciências Sociais, São Paulo, vol. 23, n. 67, jun. 2008, p. 149.

${ }^{151}$ Ibidem, p. 149.

${ }^{152}$ Cardoso, Empresário industrial e desenvolvimento econômico no Brasil. São Paulo: Difel, 1964, pp. 186-7.
} 
contra o suposto influxo "anti-industrializante", representado na época pelo latifúndio e pelo capital internacional.

Ao ler Empresário industrial pela primeira vez, ainda antes do golpe, Schwarz afirma que não estava "acostumado" com "análise dialética pessimista". "As análises dialéticas eram todas otimistas", diz ele. "O que me interessou é que você via ali um marxismo com capacidade de análise crítica do presente, em que se criticam as ilusões dos outros e se aponta para o futuro. (...) O Fernando Henrique viu que o esquema nacional-desenvolvimentista não ia acontecer", afirma. ${ }^{153}$ Além dessa dimensão prospectiva sobre os rumos da "burguesia nacional", desprovida de conflitos inconciliáveis com os grupos econômicos estrangeiros, a pesquisa de Cardoso orienta-se pela percepção ampla de que as categorias da industrialização e do desenvolvimento (tal como se apresentavam nos manuais americanos de metodologia empírico-funcional, por exemplo) não operam de maneira análoga no Brasil. Nesse sentido, a sua investigação sobre o comportamento do empresariado local, inscrita numa dinâmica internacional que não coincide com a lógica social do país (mas que é reconhecida como força dominante), busca apreender os impasses pré-1964 como um aspecto particular e significativo da reprodução do capitalismo em seu conjunto. No caso de Empresário industrial, essa reciprocidade contraditória entre as categorias elaboradas nos países centrais e a experiência brasileira - em que não se constituíam superações, mas havia história - formula-se sob o prisma da luta de classes (que fica, porém, solicitando providências práticas). ${ }^{154}$

$\mathrm{O}$ interesse atual e a abrangência política desse esforço de descompartimentação crítica não têm equivalentes diretos no primeiro ensaísmo de Schwarz. Nos seus escritos entre 1958 e 1961, a referência às categorias vinculadas ao realismo europeu não chegam a fundar, propriamente, um termo de comparação estável, dada à ausência de mediações históricas para o exame da matéria social dos romances brasileiros. Ante objetos que se afastam da ideia de obra integrada em si mesma, e que tampouco configuram temporalidades sociais ascendentes e orientadas um problema sentido, grosso modo, como insuficiência narrativa -, as categorias do

\footnotetext{
${ }^{153}$ Entrevista ao autor, op. cit.

${ }^{154}$ Paulo Arantes ressalta bem o modo como a Teoria da Dependência, em particular a sua vertente cardosista, estaria mais interessada em "desfazer à esquerda as imagens ou imaginações equivocadas a respeito do capitalismo na periferia do que em criticar a cara feia do bicho". Daí também o seu "ambíguo caráter afirmativo", que sustentaria esse acerto realista de diagnóstico. Cf. “Ajuste Intelectual”. In: O fio da meada, op. cit., p. 320.
} 
crítico sofrem abalos bruscos. Conforme discutido no capítulo anterior, Schwarz se vê às voltas com formas estéticas e sociais sacolejadas por contrastes rebarbativos, em que as experiências narradas apresentam conexões tênues entre si - estilhaçando-se a todo momento -, e o passado não se assenta numa distância objetiva. Daí também o seu sentimento de inconsistência generalizada, a partir do qual se busca dar combate ao "passadismo" e à “eloquência vazia” das obras locais, incapazes de articular vida subjetiva e "História". ${ }^{155}$ O juízo era, a seu modo, justo e inespecífico. Essa matéria ambivalente seguia desprovida de possibilidades históricas e artísticas próprias. Além disso, as objeções cortantes não eximiam Schwarz de enveredar nos caminhos do relativismo crítico. ${ }^{156}$ Assim, a visada materialista do autor, que resiste à parte da reverência apassivadora na atitude estética, num meio histórico e artístico tão inclinado às absorções cultuais, podia se converter em seu contrário. São exemplos desses volteios, entre outros, a valorização da prosa "estrelada" de Perto do coração selvagem (associada a um "substrato humano essencial", acima do tempo), a hesitação entre a "ultrapassagem" do realismo e a perda da distância n'O Ateneu, e a suposta “desobrigação" entre a fala de Grande Sertão: Veredas e a sua "realidade empírica".

A partir dessas tentativas de compatibilização entre critérios de valor contraditórios, por meio das quais o crítico reage a uma matéria entravada e escapadiça, o empenho teórico marxista de Schwarz era lido também sob o signo do aprimoramento da cultura nacional, convergindo com o ânimo progressista do país (como atestam as resenhas da época). ${ }^{157}$ Nessa imagem de uma contribuição cultural para civilizar o Brasil - em que os antagonismos são secundários -, a nota dissonante ficava ainda por conta da recepção enviesada de Bento Prado Jr., para quem a crítica de Schwarz teria configurado, ao contrário, uma "ciência selvagem”. Embora Bento

\footnotetext{
155 "Eu era um moleque arrogante, achava tudo muito inconsistente, e que isso era o clima geral. E eu ia lá cutucar. (...) No secundário, eu já sentia isso. Lembro que havia um bom professor de português. A gente lia poesia romântica brasileira. E eu também lia um pouco de poesia romântica alemã. E sentia muito o desnível. A diferença era muito grande", lembra Schwarz. Para ele, o escritor brasileiro parecia "escrever de maneira passadista e ter nostalgias e lembranças do mundo rural", numa "grande eloquência um pouco vazia". Ao mesmo tempo, Schwarz acompanha o "esforço de brasileirização muito grande" feito por Anatol Rosenfeld, autor que orienta os seus primeiros estudos literários. "O 'normal' do intelectual estrangeiro, chegando ao Brasil, é achar que tudo é muito fraco. É uma atitude de recusa. O Anatol teve a modéstia e a inteligência notáveis de se pôr a serviço da cultura brasileira, e mobilizar os conhecimentos dele para ajudar, e não para rebaixar", afirma. Entrevista ao autor, op. cit.

${ }^{156}$ Sobre o uso necessário da noção de "relativismo" crítico para o ajuizamento histórico-estético no Brasil e a construção de um cânone literário nacional, ver Pereira, Lucia Miguel. Prosa de ficção: história da literatura brasileira (de 1870 a 1920). Belo Horizonte: Itatiaia/Edusp, 1988.

${ }^{157}$ Cf., por exemplo, Arroyo, Leonardo. "Três notas". In: Folha de S. Paulo. Ilustrada, 8 ago. 1965, p. 2.
} 
reconheça na prosa do amigo um rigor construtivo que tem a "minúcia e a finura de um poema", o esforço de distanciamento crítico ali vigente estaria condicionado por um tortuoso dever ser: "Estranho Saber, esse que não se contenta com seu objeto e que lhe contrapõe a imagem do que ele deveria ser!"158 Para ele, o texto de Schwarz seria um "rio excêntrico que vem a desembocar em seu próprio nascedouro". ${ }^{159} \mathrm{E}$ essa espécie de "pororoca de laboratório" era contraposta à sua noção elevada do literário (a de Bento), concebido nos termos de uma "compensação da objetivação da linguagem" moderna. O filósofo paulista estava, a seu modo, em busca de um discurso que "não se mede mais pelo universo dos objetos", precede o campo de conhecimento das ciências sociais, e "produz a sua própria verdade". ${ }^{160}$

Nesse momento de divisão crescente do trabalho intelectual, Antonio Candido vinha ressaltando - ao menos desde o início da década de 1950 - o surgimento aqui de "padrões literários mais puros, mais exigentes e voltados para a consideração de problemas estéticos, não mais sociais e históricos", ${ }^{161}$ segundo o crítico (que tinha em mente a "Geração de 45" e, sobretudo, as neovanguardas poéticas). De fato, enquanto a ciência social uspiana, abastecida de modo mais direto pelas expectativas de modernização em curso, consolida a sua rota ascendente (cortando amarras com o ensaísmo "amadorístico" de explicação do país), o campo literário presencia a rotinização de tendências artísticas mais especializadas, multiplicando-se os casos de "gratuidade" e mesmo de "solipsismo" estético, nos termos de Candido. Nesse balanço histórico, ao mesmo tempo em que se constatava o fim da "literatura onívora, infiltrada como critério de valor nas várias atividades do pensamento", ${ }^{162}$ Antonio Candido previa que a literatura brasileira iria mesmo "retrair, se não a profundidade,

\footnotetext{
${ }^{158}$ Prado Jr., Bento. “A Sereia Desmistificada”. In: Teoria e Prática. São Paulo, 1968, n. 2, p. 72.

159 "É a febre de uma linguagem que percorre a contracorrente o seu próprio leito: Roberto escreve de trás para diante e seu texto é um rio excêntrico que vem a desembocar em seu próprio nascedouro. Mais exatamente: esse rio esquisito caminha nas duas direções e esse estilo nasce do conflito das correntes contrárias que se atravessam: a frase se arrepia no atrito e tem sempre algo de uma pororoca que não seja ruidosa e comovente, de uma pororoca de laboratório". Ver "A Sereia Desmistificada", op. cit., p. 67. Cf. Arantes, Paulo. "A musa do departamento: Bento Prado Júnior e a filosofia uspiana da literatura nos anos 60". In: Um departamento francês de Ultramar: estudos sobre a formação da cultura filosófica uspiana. Rio de Janeiro: Paz e Terra, 1994, pp. 170-234.
}

\footnotetext{
${ }^{160}$ Após a resenha de Bento Prado Jr., seriam raros os comentários mais detidos sobre a prosa crítica de Schwarz, embora seja notável o ganho em nitidez expositiva entre os seus primeiros artigos no Suplemento Literário até, por exemplo, um ensaio como "A poesia envenenada de Dom Casmurro", no final do seu ciclo machadiano. Cf. a intervenção de José Antonio Pasta Jr. em "Machado de Assis: um debate". In: Novos Estudos Cebrap. São Paulo, mar. 1991, n. 29, pp. 79-82. A citação encontra-se em Prado Jr., "A Sereia Desmistificada”, op. cit., p. 72.

${ }^{161}$ Candido, "Literatura e cultura de 1900 a 1945". In: Literatura e Sociedade, op. cit., p. 143.

${ }^{162}$ Ibidem, p. 143.
} 
certamente o âmbito" da sua ambição, após um longo ciclo em que ela havia funcionado como estimulante decisivo na vida cultural no país. ${ }^{163}$

Contudo, no momento em que Schwarz volta ao Brasil, esse processo de delimitação enviesada do "literário" também vinha sendo referido, de modo mais incisivo, ao terreno da sua prática histórica. A esse respeito, é sempre lembrado o caso dos poetas concretistas (que, para o jovem Schwarz, eram o sintoma da "estrutura da alienação como se dá em nossos dias”). ${ }^{164}$ Em julho de 1961, eles autoproclamam o seu "salto participante", durante o "II Congresso Brasileiro de Crítica e História Literária", realizado em Assis (SP). E espalham nos seus "cartazes-poemas" palavras de ordem de apoio à reforma agrária, às greves trabalhistas, à Revolução Cubana, etc. Numa entrevista ao sociólogo Marcelo Ridenti, Ferreira Gullar relata mesmo que pouco antes do golpe - o Centro Popular de Cultura da UNE (CPC) chegou a receber poemas dos concretos para publicação, o que teria causado espanto no grupo de artistas engajados. Nos termos de Gullar, "era tão grande a presença da luta política, da participação popular naquele período, que pessoas como eles se sentiam à margem de tudo, tinham perdido o bonde da História". ${ }^{165}$ É evidente, porém, que havia reações. No mesmo célebre Congresso de Assis, por exemplo, um crítico como Wilson Martins ainda saudava - como sendo a principal novidade do seu tempo - a "literatura diretamente estética, autônoma, desligada das preocupações sociológicas", na qual não haveria espaço para a "tomada de posição diante da realidade nacional", e nem amarras ou "compromisso com o país". ${ }^{166}$

\footnotetext{
${ }^{163}$ Ibidem, pp. 143-4.

${ }^{164}$ Schwarz ataca a sintaxe "regressiva" e "anti-humana" dos concretos, que se aferram à "segurança do sensível" ante as oscilações equívocas do "inteligível", segundo os seus termos. Assim, por exemplo, a valorização dos recursos gráficos e da visualidade do poema, ao invés de refutar a indisciplina subjetiva e o individualismo (como imaginam os concretos), reproduziria de modo "unívoco" a incoerência das significações concorrentes na realidade social, "que são tomadas tais quais são", desconsiderando-se a sua relatividade histórica. Esse comentário sobre o concretismo é feito após uma comunicação de Décio Pignatari sobre "A situação atual da poesia brasileira". Cf. Anais do II Congresso Brasileiro de Crítica e História Literária (24-30 jul. 1961). Assis, SP: Faculdade de Filosofia, Ciências e Letras de Assis, 1963, pp. 398-400. Uma parte dessa intervenção foi publicada por Ayala, Walmir. "O concretismo ou a agonia da onça". In: Correio da Manhã. Rio de Janeiro, 9 mai. 1964, p. 10.

${ }^{165}$ Cf. Ridenti, Marcelo. Em busca do povo brasileiro, op. cit., p. 79.

${ }^{166}$ Cf. Anais do II Congresso Brasileiro de Crítica e História Literária, op. cit., p. 182.
} 


\section{Estado de expectativa permanente}

Nas imediações de 1964, porém, alteravam-se os fundamentos sociais dessa aparência "diretamente estética, autônoma", que abrangia parte das obras brasileiras. Segundo a periodização de Antonio Candido, até o final da década de 1950, não era possível identificar fora da burguesia a presença de culturas "antagônicas" ou mesmo "paralelas" ao seu domínio, capazes de interessar camadas amplas da sociedade brasileira. Isso muda na virada para os anos 1960. Pela primeira vez, diz Candido, a cultura burguesa não "reinou incontrastada no Brasil como sendo 'a cultura". ${ }^{167}$ As elaborações problemáticas da autoimagem num país de herança colonial passam a ser concebidas "não de maneira isolada, através de vanguardas", mas a partir de "grandes movimentos de estudantes, populares e intelectuais". ${ }^{168}$ Desse modo, vinham à tona no campo da cultura, e referindo-se à nação inteira, questões relacionadas diretamente à luta pela transformação das relações de propriedade e de poder no país (marcadas pelo clientelismo, pelo mandonismo e pela pobreza sem direitos). ${ }^{169} \mathrm{Em}$ outras palavras, interpunha-se o problema político nas tentativas - teóricas ou estéticas - de articular certo fundo colonial, supostamente preservado do contágio da civilização burguesa, ${ }^{170}$ e a imensa aspiração modernizadora brasileira (manifestando-se numa sociedade que, sob processo de urbanização acelerado, ainda era predominantemente agrária). Nesse sentido, e sob a vinculação anti-imperialista entre as desigualdades de classe interna e a reprodução das relações de dependência com os países centrais, redefinia-se, em parte, a crença inata numa defasagem de nações a ser superada por meio de estratégias lineares de emparelhamento econômico e cultural.

\footnotetext{
${ }^{167}$ Cf. Candido, "Feitos da burguesia". In: Teresina etc. Rio de Janeiro: Ouro sobre Azul, p. 93.

${ }^{168}$ Ibidem, p. 93.

${ }^{169}$ Vale lembrar o modo como Antonio Candido valoriza nesse momento o romance de 1930, quando a literatura brasileira teria incorporado a "existência do povo", não sob as formas degradadas do pitoresco exótico, mas como força social "criadora de poesia e de ação". Em 1943, ele ressaltava que essa integração "estética" e "ética" das classes subalternas à imaginação literária, além de ter produzido obras de alto nível, servia como um "magnífico preparo ao aspecto político da questão, por que ainda esperamos". Essa espera parecia próxima de ser alcançada no início dos anos 1960. Sobre a recepção do jovem Candido à literatura de 1930, lida por ele como "prelúdio da 'participação efetiva (dos pobres) na cultura nacional'”, ver Otsuka, Edu Teruki. "Romance e expectativa: Antonio Candido e o romance brasileiro antes de Formação da literatura brasileira". In: Fonseca, Maria Augusta; Schwarz, Roberto (orgs.). Antonio Candido 100 anos. São Paulo: Ed. 34, 2018, pp. 343-4. A citação encontra-se em Candido, "Poesia, documento e história". In: Brigada ligeira, op. cit., pp. 41-55. Ver, do mesmo autor, o clássico "A Revolução de 1930 e a cultura". In: A educação pela noite, op. cit., pp. 219-40.

${ }^{170}$ Ao discutir a valorização modernista do substrato de informalidade brasileiro, Schwarz fala numa substituição da politica (o que, a seu modo, não deixava de ser um procedimento político), relegada ao "papel de uma superfetação dispensável”. Cf. “Outra Capitu”. In: Duas meninas, op. cit., p. 129 e 138-40.
} 
Desse modo, a rotina estreita da cultura burguesa no Brasil encontra-se tensionada - em âmbitos e níveis diversos - pela presença mais ativa das camadas pobres e marginalizadas, que alcançam uma expressão política importante entre 1961 e $1964 .{ }^{171} \mathrm{E}$ as reivindicações contra o caráter antissocial do latifúndio, por exemplo entre outras lutas da época -, entram em conexão objetiva com os movimentos de emancipação nacional do "terceiro-mundismo". A Revolução Cubana (1959), a independência da Argélia (1962) e as lutas anticoloniais na África - que seriam acompanhadas, na metade final da década, pela Revolução Cultural Chinesa e pelo acirramento da guerra no Vietnã -, compõe uma constelação histórica inconformista. Embora, posteriormente, Schwarz enfatize na "mística terceiro-mundista" a dimensão de encobrimento dos conflitos de classes, ele reconhece que essa perspectiva "deu a muita gente" da sua geração a "impressão de inventar um caminho original, melhor que capitalismo ou comunismo" soviético. ${ }^{172}$ Sob as promessas desse realinhamento histórico, artistas e intelectuais também vislumbram, no Brasil, a hipótese de uma cultura livre da dependência constritora em relação às elites dirigentes. E a busca de um flanco popular nessa troca assimétrica entre pares impulsiona, sob diferentes modos, o método Paulo Freire de alfabetização de adultos (a experiência pioneira ocorre 1963, em Angicos-RN), a trilogia da seca do Cinema Novo (1963-1964), as tentativas de teatro épico, a coleção "Cadernos do povo brasileiro" (1962-1964) e as caravanas ao Nordeste. A maioria dessas iniciativas, tateando formas mais socializadas de intervenção e produção de conhecimento - com alcance prático heterogêneo -, ${ }^{173}$ desdobram-se e se ampliam após a saída temporária de Schwarz do Brasil (em agosto de 1961).

Acresce que a representação estética desse momento de insubordinação dos pobres - marcado pela solidariedade internacional com os povos subdesenvolvidos exigia soluções de linguagem e de assunto que, via de regra, não compareciam no

\footnotetext{
${ }^{171}$ Contra a "democracia restrita" vigente no pré-1964, segundo os termos de Florestan Fernandes, "vários setores das classes trabalhadoras (mesmo de massas populares mais ou menos marginalizadas, no campo e na cidade) contavam com crescente espaço político". Ver Brasil, em compasso de espera. São Paulo: Hucitec, 1980, p. 113.

${ }^{172}$ Para uma reação mais direta de Schwarz ao viés terceiro-mundista vigente na cultura brasileira da época, ver o seu breve comentário ao "impulso revolucionário" da "Estética da fome" (1965), de Glauber Rocha. Cf. "Cultura e política, 1964-1969”, op. cit., pp. 90-1. A citação está em "Existe uma estética do Terceiro Mundo?”. In: Que horas são?, op. cit., p. 127.

${ }^{173}$ No caso do Cinema Novo, que teve limitada capacidade de constituição e incorporação de um público próprio para a produção nacional, a referência é Sales Gomes, Paulo Emílio. "Cinema: Trajetória no subdesenvolvimento". In: Uma situação colonial? São Paulo: Companhia das Letras, 2016, pp. 186-205.
} 
repertório das Letras brasileiras. Como se sabe, o componente de verbalismo prestigioso que constitui certa tradição literária nacional - ao mesmo tempo interessada na construção de uma imagem inacabada de Brasil e muito fechada num "sistema de solidariedade e reconhecimento mútuo" - ${ }^{174}$ é, historicamente, afim a uma prática de governo que recusa a generalização de direitos. A partir de meados de 1961, quando o alargamento de parcelas da inteligência brasileira em direção aos temas e problemas populares torna-se mais visível - assumindo um horizonte político radical -, esse salto não se reduz apenas a uma miragem de camadas médias intelectualizadas (embora as diversas contorções ideológicas venham à tona). Há um apoio relativo no curso da história contemporânea, na medida em que se busca responder - a partir dos meios expressivos disponíveis, e com invenção e improviso ao ascenso político real das camadas subalternas, que põem à prova a objetificação brutal que caracteriza o embate de classes no país. Assim, amplia-se a percepção de certa complementariedade entre a vida mental compartimentada do intelectual de extração culta e a situação de infra-cidadania dos pobres, ${ }^{175}$ o que leva ainda ao "reconhecimento de tipos não-burgueses de beleza" - como destacaria Schwarz -, ${ }^{176}$ articulado à procura de saídas nacionais da condição colonial-periférica.

Nas avaliações conjunturais que circulam na rua Maria Antônia, antes do golpe, a euforia transformadora e o viés hiperbólico atribuído à luta política coexistem, de modo irresoluto, com uma aversão crescente ao clima meio "avacalhado" e de "muita irresponsabilidade" - as expressões são de Schwarz vigente nas mobilizações sociais do período, que transcorriam sob as ambiguidades do governo Goulart. “O bicho-papão da época era o populismo. Todos os políticos reais eram populistas. (...) Para nós, o Goulart era corrupção sindicalista, e nada com

\footnotetext{
${ }^{174}$ Sobre o processo de constituição da "vida intelectual" no Brasil, no início do século 19, Antonio Candido sintetiza: "A raridade e dificuldade da instrução, a escassez de livros, o destaque dado bruscamente aos intelectuais (pela necessidade de recrutar entre eles funcionários, administradores, pregadores, oradores, professores, publicistas) deram-lhes um relevo inesperado. Daí a sua tendência, pelo século afora, a continuar ligados às funções de caráter público, não apenas como forma de remuneração, mas como critério de prestígio. (...) Aí se encontram por ventura as raízes da relativa jactância, reforçada a seguir pelo Romantismo, que deu aos grupos intelectuais, no Brasil, exagerada noção da própria importância e valia". Daí também a "tradição de auditório" nas letras brasileiras, marcada pela "voga da oratória, da melodia verbal, da imagem colorida", que inclui certa loquacidade perversa, própria a uma "literatura sem leitores". Cf. "A configuração do intelectual". In: Formação da literatura brasileira: momentos decisivos, 1750-1880, op. cit., p. 246. Ver, do mesmo autor, "O escritor e o público". In: Literatura e Sociedade, op. cit., p. 91 e 98.

${ }^{175}$ Ver Schwarz, "Nunca fomos tão engajados”. In: Sequências brasileiras, op. cit., pp. 172-3.

${ }^{176}$ Cf. a sua análise sobre Cabra marcado pra morrer (1984), de Eduardo Coutinho, cuja primeira filmagem é de 1962. Cf. "O fio da meada". In: Que horas são?, op. cit., p. 73.
} 
o qual uma pessoa de esquerda quisesse mexer muito", afirma Schwarz. ${ }^{177}$ Essas pressões contraditórias aparecem, por exemplo, no ensaio "A política das classes dominantes", do economista Paul Singer. Nesse texto elaborado em setembro de 1963, Paul Singer defende que a rebeldia das camadas subalternas, entre outros fatores econômicos e políticos, vinha limitando as opções do conservadorismo brasileiro, pondo em questão a "existência" mesma da burguesia "enquanto classe". Ao mesmo tempo, as "veleidades reformistas de Jango" são referidas, de modo sumário, como uma "vasta demagogia", destinada apenas a "fazer o proletariado aceitar restrições salariais e outras medidas deflacionárias". ${ }^{178}$ Nesses apontamentos, é a perspectiva da revolução que magnetiza as suas linhas de reconstituição histórica, e parece alterar o campo do possível:

É preciso compreender que os acontecimentos de agosto de 1961 a janeiro de 1962 alteraram de muito a correlação de forças no quadro político do país. Após a derrota nas eleições de 1960, a esquerda experimentou incessante crescimento de forças. (...) As soluções revolucionárias para a crise econômica, através de transformações na estrutura econômica do país, que até 1961 podiam ser apontadas de 'ideias exóticas', acabaram sendo teses oficialmente defendidas pelo governo da República. A autoridade ganha por ideias como por exemplo de que há um processo de espoliação imperialista do país, que é preciso redistribuir a terra através de uma reforma agrária etc., foi imensa. É óbvio que o progresso destas ideias não se deve exclusivamente ao seu patrocínio oficial; foram as próprias transformações da realidade e as peripécias da luta de classes que deram validade às ideias de esquerda aos olhos do povo. Mas o fato de o governo fazê-la suas, forçado pelas contingências da luta política, não deixou de contribuir para esse resultado. Pela primeira vez nestes últimos 3 lustros, se defronta a grande burguesia e o capital estrangeiro com uma esquerda no comando de poderosas organizações de massas e com real influência sobre os poderes constituídos. ${ }^{179}$

Nesse balanço histórico, o termo de comparação implícito é o ciclo grevista de 1953 a 1957 - no qual Paul Singer havia se engajado como metalúrgico -, e que foi marcado pela retomada dos protestos por reajuste salarial e contra a elevação do custo de vida em São Paulo, após anos de repressão intensificada contra a organização dos trabalhadores. Para o economista, essas paralisações - em particular, a “Greve dos 300

\footnotetext{
${ }^{177}$ Entrevista ao autor, op. cit.

${ }^{178}$ Singer, Paulo. "A política das classes dominantes". In: Política e revolução social no Brasil. Rio de Janeiro: Civilização Brasileira, 1965, p. 116.

${ }^{179}$ Ibidem, pp. 114-5.
} 
mil" (1953) - teriam servido mais como uma "escola para o movimento sindical". ${ }^{180}$ A partir da crise de 1961, marcada pela renúncia de Jânio Quadros e pela "Campanha da Legalidade" - que adia outra tentativa de golpe -, ocorre uma mudança verdadeiramente decisiva na luta política, segundo Paul Singer. Nas suas palavras, "pela primeira vez, nestes últimos 18 anos, a grande burguesia nacional e seus sócios imperialistas tiveram que se defrontar com as massas num choque direto". ${ }^{181}$ Ainda que as ideias à esquerda não tenham se convertido em força material majoritária no pré-1964, a sua radicação histórica ampliada permitia a muitos imaginar formas políticas e culturais de representação por meio do dissenso de classe no Brasil. E, nesse sentido, o fortalecimento das demandas por mínimos materiais na vida popular convertia-se, às vezes, na visão da ultrapassagem iminente de uma ordem capitalista em suposta crise de acumulação. Está claro que Paul Singer também sonhava alto, mas essas fantasias políticas formulam-se num momento em que, de fato, aumenta a pressão social sobre as formas irresolutas do estatuto da terra no Brasil, uma das cláusulas pétreas do "desenvolvimento nacional".

De qualquer modo, esse entusiasmo com a resistência aos militares contrários à posse de Jango, impasse que teve por efeito catalisar a participação popular, seria compartilhado por vários outros autores, com pressupostos teóricos e políticos divergentes. É o caso, por exemplo, do sociólogo Carlos Estevam Martins, ligado ao nacionalismo isebiano, e que foi o primeiro presidente do CPC da UNE, fundado em 1961. Para Martins, a queda de Jânio e o sucesso temporário da "legalidade" difundem entre as classes sociais um clima de ascensão das forças populares. E teriam consolidado certo sentimento íntimo - em particular, entre os artistas e intelectuais de que "cada um era absolutamente indispensável à marcha da História". ${ }^{182}$ No Rio de Janeiro, o centro da vaga nacional-popular, "todos os que depois viriam a fazer parte do CPC participaram da luta pela legalidade, junto com Brizola, o III Exército, a UNE, a CGT, os sindicatos, o movimento camponês, etc.”, afirma. De agosto de 1961 a abril de 1964, diz ele, "tínhamos a perfeita sensação de que as classes populares

\footnotetext{
${ }^{180}$ Cf. entrevista a Mori, Kiyomori. "Greve dos 300 mil foi escola de sindicalismo". Folha de S. Paulo, Cotidiano, 6 jan. 2004, p. 2.

${ }^{181}$ Singer, Paulo. “A política das classes dominantes”, op. cit., p. 112.

${ }^{182}$ Martins, Carlos Estevam. "História do CPC”. In: Arte em Revista. São Paulo: Kairós, 1980, n. 3, p. 81.
} 
haviam vencido". Segundo Martins, "todo aquele fervor só tinha uma justificação: a ideia de que íamos chegar lá, e muito rapidamente". ${ }^{183}$

A esse respeito, mesmo o cientista político Francisco Weffort - que não ignora o potencial de conflito na integração "populista" das massas urbanas, mas destaca a "falta de autonomia" desses trabalhadores - argumenta, ao final de 1963, que a “impotência política dos grupos dominantes permite vislumbrar grandes transformações na estrutura de poder". ${ }^{184}$ Em breve, previa Weffort, não haveria lugar para o "espírito conciliador" brasileiro, que entraria numa “crise irremediável". Ele também afirma que, desde agosto de 1961, a margem de compromisso pelo alto entre as classes no país havia sido reduzida. No entanto, o quadro político permanecia "essencialmente estático". ${ }^{185}$ Para Weffort, "grupo nenhum pretende tomar a iniciativa de abrir o processo de luta, inseguros todos eles sobre os resultados finais". ${ }^{186}$ Os setores populares, que chegavam em grande número do campo para a cidade, estariam sob o "fascínio do Estado", "anestesiados pelo vício da colaboração", e ressentindo-se da "paralisia" do sistema político. ${ }^{187}$ Mesmo quando pressionam o poder, o que ocorreria por meio de "demagogos e do nacionalismo", os trabalhadores "confirmam-no, estabelecem a sua legalidade", e não se fazem representar no espaço político. ${ }^{188}$ Nessa leitura, que se apresentaria como chave explicativa para a derrota de 1964, o "populismo" surge como um fenômeno "pequeno-burguês", que teria obscurecido o sentido de uma moderna ação política de classe, dotada de concepções de mundo estruturadas e coerentes entre si. Voltado à falta de respostas classistas à

\footnotetext{
${ }^{183}$ Ibidem, p. 80.

${ }^{184}$ Weffort avalia que a "geral dependência política" das camadas populares seria "um dos traços mais importantes da situação política" brasileira pré-1964. Ele afirma: "Não se sabe de nenhum movimento de opinião realizado nos últimos anos que tenha mantido, ante os governos, a relativa independência que se conseguiu atingir, por exemplo, na campanha do petróleo. Em geral, tais movimentos definem objetivos vagos de esclarecimento popular, através de conferências, debates, congressos, etc., cujo conteúdo se dissolve e não consegue concretizar-se de forma organizada", afirma. O seu argumento, porém, nem sempre distingue as insuficiências ideológicas do nacionalismo e a função real dessa ideologia, cujos resultados às vezes contradiziam e ultrapassavam o seu enquadramento inicial (como se vê em parte das produções culturais do período e na dinâmica de luta das Ligas Camponesas, por exemplo). Esse texto seria o capítulo inicial de "Classes populares e política: contribuição ao estudo do populismo". Tese (Doutorado em Ciência Política) - USP, 1968. Cf. "Política de Massas". In: Política e revolução social no Brasil, op. cit., pp. 162-3 e 167.
}

\footnotetext{
${ }^{185}$ Ibidem, p. 162.

${ }^{186}$ Ibidem, pp. 162-3.

${ }^{187}$ Ibidem, p. 171.

${ }^{188}$ Ibidem, p. 170.
} 
dominação social corrente, esse diagnóstico influi nos debates travados na Maria Antônia às vésperas do golpe, como relata Fernando Henrique Cardoso:

Após chegar a São Paulo (vindo do Comício da Central do Brasil), houve
uma reunião na faculdade, à noite, em que estavam o Weffort, a Lourdes
Sola, todo mundo - e queriam fazer um manifesto contra o Jango. Aí eu e o
Luiz Hildebrando, comunista, companheiro meu de muitos anos, fomos
para lá, porque queriam fazer um manifesto contra o Jango na noite do
golpe! E o Weffort era um dos mais exaltados. Era difícil; e o pessoal na
USP era tão anti-populista que achava que podia vir golpe dos dois lados.
(...) A dificuldade de entender o jogo real da política era muito grande para
os universitários que moravam em São Paulo. Havia muita confusão sobre
o que iria acontecer: "o golpe vem de cá ou vem de lá?". 189

Dado o componente de semostração que orienta essa fala de Cardoso, caberia acrescentar que o sociólogo antes não acreditava na hipótese de um golpe de Estado iminente. Em conversa com amigos, no dia do Comício da Central - realizado em 13 de março -, ele teria compartilhado a avaliação de "que não havia a menor dúvida, que (o Brasil) ia para o socialismo", segundo depoimento de Plínio de Arruda Sampaio. ${ }^{190}$ Seja como for, mais do que repertoriar as diferentes posições no campo progressista pré-1964, interessa fixar o consenso teórico e ideológico que o sustenta. Nas imediações do golpe, socialistas, nacionalistas e cristãos de esquerda confiam que a industrialização tardia e relativamente consentida, centrada numa possível concertação econômico-estatal autônoma, contribuiria para o surgimento de formas integradas e incisivas de luta entre capital e trabalho no Brasil, de modo a romper o vasto domínio das relações de dependência pessoal direta, e abrir uma via de acesso a direitos para além do mundo exclusivo dos mandatários locais (o que poderia ou não apontar para o socialismo, segundo as convicções predominantes). Na rua Maria Antônia, essa expectativa convive com a tese - amplamente difundida - de que o período entre a renúncia de Jânio e o golpe de 1964 vinha sendo caracterizado pelo “imobilismo" das forças políticas, incluindo-se nesse impasse um proletariado que

\footnotetext{
189 "Entrevista com Fernando Henrique Cardoso" (a Pedro Luiz Lima). In: Revista Estudos Políticos. Rio de Janeiro, 2013, n. 6, p. 13.

${ }^{190}$ Cf. entrevista a D’Agostino, Rosanne. “"Era coisa quase de soco', conta Plínio sobre sessão que depôs Jango”. G1, São Paulo, 31 mar. 2014. Disponível em: http://g1.globo.com/politica/50-anos-do-golpemilitar/noticia/2014/03/era-coisa-quase-de-soco-conta-plinio-sobre-sessao-que-depos-jango.html. Acesso em: 10 out. 2018.
} 
"não dispõe de um grau de coesão política" para sequer formular os seus interesses históricos "de maneira clara”, como dizia Gabriel Cohn, por exemplo. ${ }^{191}$

A novidade, porém, é que o arranjo autoritário constitutivo do longo ciclo desenvolvimentista brasileiro - sustentado por formas cruentas de rebaixamento do custo da força de trabalho - tinha que lidar, então, com o assédio imprevisto de uma “grande mobilização social das 'pessoas comuns', trabalhadores surpreendentemente sem cabresto à frente", nos termos de Paulo Arantes. ${ }^{192}$ E essa aspiração de desafogo das camadas subalternas, que se expressa com seus limites e ambivalências históricas - num país em que a força de trabalho nunca foi socialmente ou culturalmente homogênea -, demonstra "capacidade política de organização", o alvo mesmo do recrudescimento punitivo pós-1964. ${ }^{193} \mathrm{Na}$ época, o anseio de incorporação moderna das massas urbanas e rurais numa futura sociedade nacional do trabalho apoia-se, em parte, nesse inconformismo social crescente, que se manifesta - entre outros modos por meio de um aumento exponencial do índice de greves no país. Entre 1958 e 1960, haviam ocorrido cerca de 180 paralisações. Esse número salta para 430 episódios grevistas no triênio 1961-1963, parte deles com caráter explicitamente político, e por vezes escapando ao controle das direções sindicais e das confederações de classe, que haviam se reestruturado na década de 1950 , sob a tutela da legislação getulista. ${ }^{194}$ Nos termos de Francisco de Oliveira, vigorava no país certa dinâmica de "deslizamentos e substituição de classes", que era algo tangível e fantasmagórico, acirrando-se uma "vertigem da aceleração" no tempo social brasileiro. ${ }^{195}$

De fato, essa percepção de que se transpunha um limiar histórico no país orienta várias obras teóricas e artísticas no pré-1964. Um dos exemplos notáveis é $A$ pré-revolução brasileira (1962), de Celso Furtado. Nesse escrito, o economista realiza um esforço de conexão com a fase radicalizada do desenvolvimentismo. E o faz defendendo a tese de que o Brasil teria alcançado a diferenciação progressiva de

\footnotetext{
${ }^{191}$ Cohn, Gabriel. "Perspectiva da esquerda". In: Política e revolução social no Brasil, op. cit., pp. 151-2.

${ }^{192}$ Arantes, Paulo. "1964". In: O novo tempo do mundo: e outros estudos sobre a era da emergência. São Paulo: Boitempo, 2014, p. 294.

${ }^{193}$ A expressão é de Paulo Arantes. Ibidem, p. 294.

${ }^{194}$ O levantamento sobre o número de greves nesse período encontra-se em Toledo, Caio Navarro de. O governo Goulart e o golpe de 1964. São Paulo: Brasiliense, 1987, p. 19.

${ }^{195}$ Oliveira, Francisco de. "O adeus do futuro ao país do futuro: uma biografia breve do Brasil". In: Brasil: uma biografia não autorizada. São Paulo: Boitempo, 2018, p. 51.
} 
um sistema industrial, induzido pelo Estado, o que tornaria possível a superação dos "ziguezagues" intermitentes de economia e cultura reflexas. Nos seus termos clássicos, o eixo de propulsão do desenvolvimento poderia ser firmado no "mercado interno", entendido como um passo necessário rumo a certo processo de homogeneização da sociedade de classes, através da difusão do progresso técnico, do nexo salarial e da distribuição de renda. A partir dessa internalização das alavancas de decisão econômica, generalizava-se a "consciência de que o país caminha para transformações de grande alcance", numa "autêntica fase pré-revolucionária", segundo Furtado. ${ }^{196}$ Os seus juízos históricos tornam-se enfáticos. E ele enuncia que "a velha estrutura colonial está enterrada no passado". Ou seja, teria ficado para trás a época em que "não podíamos mais que perscrutar as tendências da economia internacional, como quem perscruta o tempo para defender-se de um vendaval". ${ }^{197}$ No presente, diz o autor, "já não somos uma matéria amorfa que se modifica ao sabor dos altos e baixos dos mercados mundiais". ${ }^{198}$ Para Furtado, o desenvolvimento do país havia alcançado mesmo uma "fase de semi-automatismo", e, "quaisquer que sejam os obstáculos que se lhe anteponham, tudo indica que ele seguirá adiante". ${ }^{199}$

É claro que esses prognósticos, feitos por um representante célebre da tradição empenhada brasileira - entre a atividade intelectual e os encargos construtivos de administração do Estado -, e que estava em litígio com a tradição conservantista do país, revelam hoje - de imediato - o seu teor excessivo. De fato, a dimensão própria da luta de classes não chega a exercer a função de mediação nessas análises econômicas. E Furtado, assim, subestima o peso político das forças sociais em confronto no país. No entanto, é por meio desses limites que A pré-revolução brasileira testemunha e caracteriza, a seu modo, o "estado de expectativa permanente" da intelectualidade progressista. ${ }^{200}$ De qualquer maneira, essas narrativas portadoras de projeções no devir, que se multiplicam no pré-1964, ${ }^{201}$ buscam superar um nexo societário fundado

\footnotetext{
${ }^{196}$ Furtado, Celso. A pré-revolução brasileira. Rio de Janeiro: Fundo de Cultura, 1962, p. 13.

${ }^{197}$ Ibidem, p. 10 e 68.

${ }^{198}$ Ibidem, p. 115.

${ }^{199}$ Ibidem, p. 10 e 68.

${ }^{200}$ A expressão é de Furtado. Ibidem, p. 41.

${ }^{201}$ Uma amostra literária, elaborada num plano mais modesto, é o "Poema para ser cantado", de Paulo Mendes Campos. Nesse caso, a certeza de que viria a revolução assume a forma contraditória de um esconjuro contínuo e fervoroso. João Luiz Lafetá destaca o problema, mas para assinalar apenas a "absoluta ausência de desconfiança
} 
estritamente nas trocas mercantis e na violência. E não se orientam, apenas, pela guerra de posição em espaços institucionais regidos pela lógica do inacabamento permanente. Para Schwarz, a política "estava em toda parte, talvez mais viva fora do que dentro das organizações propriamente ditas", numa "radicalização difusa" que se mostraria, segundo ele, "maior do que a capacidade de ação efetiva". ${ }^{202}$

\section{3. "Pra que serve fuzil que não dá tiro?"}

Até esse momento de alternativas políticas em disputa, em que as coordenadas do capitalismo pareciam em jogo na atualidade do Brasil, o juízo mais recorrente de Schwarz sobre a experiência brasileira, tal como essa se configura nos objetos literários por ele analisados, relaciona-se à percepção de uma temporalidade social "alheia" e mesmo "incompatível" com a "História". Analisando O amanuense Belmiro (1937), de Cyro dos Anjos, Schwarz afirma que ali a história parece se "apagar". Ele fala num "antitempo do cotidiano". ${ }^{203}$ Em Abdias (1945), do mesmo autor, o "tempo do mundo" seria mera "aparição casual". ${ }^{204}$ No caso de Perto do Coração Selvagem (1943), de Clarice Lispector, a passagem do tempo "comparece para melhor se anular", segundo os seus termos. ${ }^{205}$ Sobre O Ateneu (1888), de Raul Pompeia, destaca-se novamente o problema da "anulação do tempo", desprovido da sua diferenciação interna. ${ }^{206}$ Já o seu estudo sobre Mário de Andrade examina, de modo mais detido, uma teorização do poético marcada por "polaridades irredutíveis", que não se resolvem. No entanto, o crítico vincula diretamente esse descompasso a uma apreensão "psicologista" do tempo, operada pelo poeta modernista, que estaria

diante das imagens 'redentoristas' do povo". Ver "Traduzir-se". In: A dimensão da noite e outros ensaios. São Paulo: Duas Cidades/Ed. 34, 2004, p. 189 e 191. "Poema para ser cantado". In: Violão de Rua. Rio de Janeiro: Civilização Brasileira, 1962, vol. 1, pp. 64-7.

\footnotetext{
${ }^{202}$ Sobre a atuação da "ordem empresarial" na preparação e no desencadeamento do golpe, cf. Dreifuss, René. 1964: a conquista do Estado - Ação política, poder e golpe. Petrópolis: Vozes, 1981. Para a discussão dos seus desdobramentos contemporâneos, ver Arantes, Paulo. "1964". In: O novo tempo do mundo, op. cit., pp. 281-314. A citação encontra-se em "Roberto Schwarz”. In: Retrato de grupo, op. cit., p. 236.

203 “Tempo de ficar velho”. In: Suplemento Literário d'O Estado de S. Paulo, 31. jan. 1959, p. 39.

${ }^{204}$ Ibidem, p. 3.

205 “Entre ser e parecer”. In: Suplemento Literário, 19 set. 1959, p. 39.

206 “O Atheneu e o naturalismo". In: Suplemento Literário, 10 set. 1960, p. 40.
} 
confinado num "círculo pré-dialético". ${ }^{207}$ Nessas definições pelo que a literatura brasileira não é, a própria crítica de Schwarz tende a se debater numa dimensão teórica em que não se passa, de modo efetivo, ao plano histórico.

No caso do trabalho sobre Mário de Andrade, o último ensaio publicado pelo autor antes da sua ida a Yale, Schwarz supõe que a dita defasagem "psicologista" poderia ser devidamente emparelhada, por assim dizer, à dimensão de continuidade e consequência social própria à moderna tradição estética europeia, incorporando o seu esprit de suite (num atrito mais subsistente com a matéria histórica). A aposta, que constitui um dos pontos de fuga desse primeiro conjunto de ensaios, fica sem desdobramento teórico ou político nos seus trabalhos anteriores ao golpe. Isso porque ele voltaria a publicar análises sobre assunto brasileiro apenas em 1966, já sob a ditadura. Nesse ano, a revista Civilização Brasileira faz circular o seu ensaio "Sobre O amanuense Belmiro", redigido em 1964, e o crítico escreve "O cinema e Os fuzis" (textos que serão discutidos adiante). Por ora, cabe destacar esse lapso de aproximadamente cinco anos sem publicações sobre o país (maio de 1961 a meados de 1966). O afastamento temporário contrasta com a sua produção profícua entre 1958 e 1961, quando o autor escreve dez artigos sobre obras nacionais. ${ }^{208} \mathrm{E}$ abrange todo o período 1962-1964, que Schwarz definiria em 1985 como o "momento cultural mais fecundo vivido no Brasil de algum tempo para cá". ${ }^{209}$ De fato, a ausência de amparo textual nesse estágio decisivo da vida brasileira, vivenciado pelo autor em seus instantes finais (os dez meses anteriores ao golpe), torna intrincada a tarefa de apreender a posição social da crítica de Schwarz às vésperas de 1964.

No entanto, há ao menos um trabalho não-publicado por Schwarz que poderia sugerir, em linhas gerais, como a conjuntura pré-1964 mobiliza os seus procedimentos críticos. Na semana anterior ao golpe, ele se organiza com o diretor de teatro Augusto Boal e o arquiteto e cenógrafo Flávio Império para redigir uma matéria de agitação

\footnotetext{
207 “O psicologismo na poética de Mário de Andrade”. In: Suplemento Literário, 20 mai. 1961, p. 44.

${ }^{208}$ Na volta ao Brasil, após o mestrado em Yale (1961-1963), Schwarz prepara o seu curso na área de Teoria Literária e Literatura Comparada da USP. Como primeiro professor-assistente de Antonio Candido, ele assume a disciplina de "Introdução aos Estudos Literários". As suas primeiras aulas, voltadas à discussão de contos de Machado de Assis, são ministradas em 1964. "Eu ensinava a fazer análise de contos a partir de Machado, mas não era um curso 'sobre Machado"”, afirma. Entrevista ao autor, op. cit.

${ }^{209}$ No contexto em que foi formulado, esse juízo sobre os anos 1962-1964 ganha uma nota específica, com teor de provocação política, relacionada à feição decepcionante da "Abertura" política. Cf. "A questão da cultura". In: $L u a$ Nova. São Paulo, mar. 1985, vol. 1, n. 4, pp. 27-8.
} 
política para o jornal Última Hora. A imprensa fervilhava de reportagens e editoriais sobre as lutas camponesas no Nordeste, assumindo um tom ostensivo de campanha ideológica. ${ }^{210} \mathrm{E}$ uma das reações alarmistas vinha das páginas d'O Estado de $S$. Paulo. No início de 1964, o jornal tinha enviado uma equipe ao sertão para acompanhar in loco uma ocupação de terras. Sob o enfoque na turbulência dos pobres e no perigo socialista, o destaque era dado às tribulações de um fazendeiro local, que, após uma revolta de trabalhadores sem terra, foi encontrado amarrado nas costas de um burro de carga. O animal e o patrão, de modo indistinto, teriam sido "tocados" pela estrada até a cidade. Essa inversão no domínio de classe servia, no caso, a uma visão moral sobre o rompimento das relações de lealdade e favor dos trabalhadores para com os senhores de terra, buscando-se ativar o pânico ante qualquer tentativa mesmo incipiente - de organização popular no campo. “O 'Estadão' ficava horrorizado. E para uma pessoa de esquerda, ao contrário, era o máximo. Era uma coisa simpaticíssima. Eu li, fiquei entusiasmado e mostrei para o Boal", diz Schwarz. $^{211}$

Por iniciativa de Boal, que tinha contatos no Última Hora, e utilizando como pauta a ação direta descrita pelo "Estadão", eles planejam um texto de intervenção sobre esse momento histórico em que parcelas dos camponeses, expulsos de suas terras e acossados pelo aumento do sobretrabalho - o chamado "cambão", o trabalho não-pago que o lavrador precisa conceder ao proprietário -, emergem como sujeitos políticos no Brasil, contribuindo para romper o confinamento regional dos conflitos agrários. ${ }^{212}$ Numa divisão de tarefas, Boal fica responsável por elaborar dramatizações sobre a viravolta dessa camada social silente no imaginário trabalhista. Flávio Império concebe a disposição gráfica da página. E Schwarz, por sua vez, assume a parte poética. No seu trabalho, o crítico afirma ter selecionado trechos de poemas de João Cabral de Melo Neto, buscando redimensionar certa dignidade

\footnotetext{
${ }^{210}$ Desde os anos 1950, a denúncia da "indústria da seca" e as agitações sociais no Nordeste tornam-se notícia nos jornais do Centro-Sul, entrando no radar da política externa estadunidense. Entre 1961 e 1964, porém, a questão agrária ganha significação ideológica ampliada, sob o objetivo alegado de extirpar no Brasil o embrião imaginário de uma "China dos anos 1960". Tratava-se, então, do Nordeste: problema número um (1962), como dizia o título do primeiro filme de propaganda do Instituto de Pesquisas e Estudos Sociais (Ipes). Cf. Furtado, Celso. "A fantasia desfeita”. In: Obra autobiográfica. São Paulo: Companhia das Letras, 2014, pp. 238-43 e 302-3. Ver ainda Page, Joseph. A revolução que nunca houve (O Nordeste do Brasil 1955-1964). Rio de Janeiro: Record, 1972.

${ }^{211}$ Entrevista ao autor, op. cit.

${ }^{212}$ Para uma referência teórica a respeito, ver Oliveira, Francisco de. Noiva da revolução/Elegia para uma re(li)gião: Sudene, Nordeste, Planejamento e conflitos de classes. São Paulo: Boitempo, 2008, pp. 218-20.
} 
dramática conferida aos trabalhadores rurais para um "contexto político mais direto", ${ }^{213}$ no qual a referência à luta pela reforma agrária vincula-se à perspectiva revolucionária. O golpe da direita, entretanto, ocorre no dia seguinte à entrega do material. No Rio de Janeiro, a principal redação do Última Hora seria invadida e depredada por bandos paramilitares. ${ }^{214}$ Essa página se perdeu e nunca veio a público.

A partir de intervenções diretas como essa - cancelada por motivo policial -, Schwarz reconhece analogias entre o modo como se redefiniam os sentidos culturais e políticos da sua atividade crítica, sob o acirramento da luta de classes no Brasil, e as experimentações teatrais de Augusto Boal no Teatro de Arena, por exemplo. Como se sabe, Boal era impelido - sobretudo, a partir de Revolução na América do Sul (1960) a reinventar localmente formas de teatro narrativo, quando a radicalização pré-1964 trazia à ordem do dia a questão da luta pelo poder político. Nas suas práticas cênicas, em particular, ele pôde intuir descompassos entre as convenções do drama burguês, fundado num fechamento absoluto do diálogo intersubjetivo, ${ }^{215}$ e os impasses amplos de uma economia periférica que ansiava dar o salto para além do subdesenvolvimento (e que eram trazidos ao palco pelo Arena). Já Schwarz, recém-chegado da sua imersão acadêmica nos Estados Unidos - marcada por uma separação entre imaginação literária e vida social que ele recusa -, reconhecia que o interesse artístico no Brasil estava se deslocando para o "contato popular". "Eu vinha lá de Yale e aqui, de repente, os meus recursos literários eram convocados de outro jeito", afirma. ${ }^{216}$ Essa perspectiva de socialização da cultura alterava a "tônica" dos trabalhos intelectuais. Ou seja, "politizou muito, desaburguesava", e o "poético passa a ser outra coisa", que resta definir melhor. ${ }^{217}$

Schwarz conta que, para ele, essas passagens entre arte e política no pré-1964 tiveram como "micromodelo" as excursões do Arena ao Nordeste. Nesse caso, vale a pena retomar, ainda que seja em linhas breves - e no âmbito do problema delimitado no capítulo -, essa experiência referida pelo crítico. A mais importante dessas viagens

\footnotetext{
${ }^{213}$ Entrevista ao autor, op. cit.

${ }^{214}$ Cf. “A vindita fria”. In: Última Hora. Rio de Janeiro, 2 abr. 1964, p. 1.

${ }^{215}$ Sobre a crise do drama, entendido como forma historicamente constituída, a referência clássica é Szondi, Peter. Teoria do drama moderno (1880-1950). São Paulo: Cosac Naify, 2011.

${ }^{216}$ Entrevista ao autor, op. cit.

${ }^{217}$ Entrevista ao autor, op. cit.
} 
de "descoberta do Nordeste" ocorre no segundo semestre de 1961. A partir de articulações com as Ligas Camponesas, os setores progressistas da Igreja católica e o recém-criado Movimento de Cultura Popular de Pernambuco (MCP), o Arena visita vilarejos conflagrados na luta por direito à terra, em busca do "Brasil verdadeiro" e do "povo autêntico", segundo Boal. ${ }^{218} \mathrm{E}$ os atores encontram ali uma oportunidade de remeter o seu material artístico à práxis social em termos mais diretos, encenando esquetes do que viria a ser a peça Mutirão em Novo Sol. ${ }^{219}$ Essa obra é escrita em 1961 por Nelson Xavier (que logo depois se juntaria ao MCP), em coautoria de Boal, e com a colaboração de Modesto Carone, Hamilton Trevisan e Benedito Araújo. E destaca-se por se apoiar, desde o início, numa interlocução direta com a fração mais avançada da luta social da época. O seu primeiro material dramatúrgico surge em janeiro de 1961, a partir do diálogo entre os integrantes do Arena e o líder camponês Jôfre Corrêa Netto, que havia acabado de sair da prisão. ${ }^{220}$ Ele tinha participado da rebelião do "Arranca Capim" (1959), que chegou a reunir mais de 800 famílias de pequenos lavradores arrendatários ameaçados de expulsão de suas terras, em Santa Fé do Sul (SP). Na ocasião, esse grupo de colonos se insurgiu contra os planos do proprietário, que pretendia criar pastos para gado de corte em terras de subsistência, visando exportar carne ao mercado internacional. Essa mobilização, que ganha projeção nacional, serve como roteiro para Mutirão, que antecede um conjunto de montagens de temática camponesa surgidas no país entre 1963 e $1964 .^{221}$

Nessa viagem ao Nordeste, os atores do Arena experimentam técnicas de composição épica para dramatizar e transpor em ato, com os camponeses - que, em sua maioria, viam teatro pela primeira vez -, aspectos da luta pela superação do trabalho semicompulsório no país. Apoiando-se em modalidades do teatro tribunal de

\footnotetext{
${ }^{218}$ Boal, Augusto. Hamlet e o filho do padeiro: memórias imaginadas. São Paulo: Cosac Naify, 2014, p. 210.

${ }^{219}$ Iná Camargo Costa afirma que "tudo indica" que cenas de Mutirão são apresentadas nessa tournée de 1961. Recentemente, foi publicada uma edição crítica da peça, esquecida por mais de meio século. Cf. A hora do teatro épico no Brasil. Rio de Janeiro: Paz e Terra, 1996, pp. 94-6. E Xavier, Nelson. Mutirão em Novo Sol. São Paulo: Expressão Popular, 2015.

${ }^{220}$ Perseguido pela polícia, Jôfre voltaria a ser encarcerado durante quase todo o período de maior radicalização política no Brasil, entre setembro de 1962 e maio de 1964. Cf. Welch, Clifford Andrew. "Jôfre, Roque e a Guerra do Capim". In: Xavier, Nelson. Mutirão em Novo Sol, op. cit., p. 108. Ver, do mesmo autor, Jôfre Côrrea Netto Capitão Camponês (1921-2012). São Paulo: Expressão Popular, 2010.

${ }^{221}$ Segundo Rafael Villas Bôas, Mutirão é a primeira peça teatral brasileira em que o "meio rural deixa a condição de cenário, e seus personagens abandonam a pitoresca condição de caipiras interioranos, (...) ou de personagens secundários de dramas da elite". Cf. Teatro político e questão agrária, 1955-1965: contradições, avanços e impasses de um momento decisivo. 233 f. Tese (Doutorado em Teoria Literária e Literaturas) - UnB, 2009, p. 69.
} 
Piscator e do teatro épico de Brecht, Mutirão aposta no surgimento local de uma cultura política nova, na qual os critérios artísticos poderiam se erigir e reformular-se no bojo de uma luta popular ascendente. No caso de Pernambuco, em particular onde o Arena esteve várias vezes, em contato com o governo Arraes -, anunciam-se possibilidades amplas de ação política para as camadas subalternas. A partir de 1963, com a ampliação do crédito agrícola no estado, um número maior de lavradores pobres estruturam o seu trabalho em cooperativas, desenvolvidas até certo ponto em termos próprios. De fato, entre 1961 e 1963, as montagens de Mutirão encontram o seu destinatário social, alcançando "multidões de lavradores pobres de Pernambuco, Paraíba e Bahia". ${ }^{222}$ Sem se conceber como uma obra durável, a peça incorpora reformulações a partir de questionários de pesquisa feitos com os camponeses. Daí também a imagem superlativa de Gianfrancesco Guarnieri, que se refere à Mutirão como uma "peça de ' 25 mil' autores". ${ }^{223}$ Contudo, ao rememorar as apresentações no Nordeste, Boal ressaltaria um desacordo traumático entre a prática artística do grupo e os propósitos político-sociais dos trabalhadores:

(...) Um belo dia estávamos representando um desses belos musicais em um vilarejo do Nordeste, numa Liga Camponesa. Plateia emocionada, só de camponeses. Texto heroico, "Derramemos nosso sangue!" No fim do espetáculo aproximou-se de nós um camponês alto, enorme, forte, um homem emocionado, quase chorando:

- "É uma beleza ver vocês, gente moça da cidade, que pensa igualzinho que nem a gente. A gente também acha isso, que tem que dar o sangue pela terra."

Ficamos orgulhosos. Missão cumprida. Nossa "mensagem" tinha passado! Mas Virgílio - nunca mais esquecerei nem seu nome nem seu rosto, nem sua lágrima silenciosa - Virgílio continuou:

- "E já que vocês pensam igualzinho que nem a gente, vamos fazer assim: primeiro a gente almoça (era meio-dia), depois vamos todos juntos, vocês com esses fuzis de vocês e nós com os nossos, vamos desalojar os jagunços do coronel que invadiram a roça de um companheiro nosso, puseram fogo na casa e ameaçaram matar a família inteira! Mas primeiro vamos comer.”

Perdemos o apetite.

\footnotetext{
${ }^{222}$ A primeira montagem é realizada sob a direção de Chico de Assis, por ocasião da I Conferência de Lavradores do Estado de São Paulo, em novembro de 1961. A partir dali, as encenações de Mutirão mobilizam, além do Arena, o MCP de Pernambuco, o CPC de São Paulo, o CPC da Bahia, o CPC de Goiás e atores do Teatro Oficina. Cf. Toledo, Paulo Bio; Neiva, Sara Mello. "Mutirão em Novo Sol e o experimentalismo político no teatro brasileiro da década de 1960". In: Revista aSPAs. São Paulo, 2015, vol. 5, n. 2, pp. 67-80.

${ }^{223}$ Cf. entrevista a Barcellos, Jalusa. CPC da UNE - uma história de paixão e consciência. Rio de Janeiro: Nova Fronteira, 1994, p. 241.
} 
Tentando organizar os pensamentos e as meias frases, fizemos o possível para explicar o mal-entendido. $O$ argumento que nos pareceu mais verdadeiro foi dizer a verdade: nossos fuzis eram objeto de cenografia e não armas de guerra.

- "Fuzil que não dá tiro???" - perguntou espantadíssimo. "Então pra que é que serve?"

- "Pra fazer teatro. São fuzis que não disparam. Nós somos artistas sérios que dizemos o que pensamos, somos gente verdadeira, mas os fuzis são falsos."

- "Se os fuzis são de mentira, pode jogar fora, mas vocês são gente de verdade, eu vi vocês cantando pra derramar sangue, sou testemunha. Vocês são de verdade, então venham com a gente assim mesmo porque nós temos fuzis pra todo mundo."

O medo fez-se pânico. Porque era difícil explicar - tanto para Virgílio como para nós mesmos - como é que nós estávamos sendo sinceros e verdadeiros empunhando fuzis que não disparavam, nós, artistas, que não sabíamos atirar. Explicamos como pudemos. Se aceitássemos ir juntos, seríamos estorvo e não ajuda.

- "Então aquele sangue que vocês acham que a gente deve derramar é o nosso, não é o de vocês...?"

- "Porque nós somos verdadeiros sim, mas somos verdadeiros artistas e não verdadeiros camponeses... Virgílio, volta aqui, vamos continuar conversando... Volta..."

- Nunca mais encontrei Virgílio. ${ }^{224}$

Esse impasse entre certa dimensão de gratuidade estética da peça e a demanda de eficácia do seu conteúdo artístico, que conclama à resistência armada no campo, precipita-se em presença de uma força mobilizada pela luta de classes. Nas memórias de Boal, porém, o episódio serve para evocar os limites do "antigo" teatro político dos anos 1960, "demasiado geral" e "exortativo". ${ }^{225}$ Ao criticar a "forma mensageira" da peça ("nós não éramos capazes de seguir o nosso próprio conselho", diz Boal), ele tende a aferir o valor dessa experiência passada pelo "grau de concretização das sugestões simbólicas da cena". ${ }^{226}$ Ao mesmo tempo, o seu relato traz ao primeiro

\footnotetext{
${ }^{224}$ Essa cena no Nordeste seria retomada por Boal em vários debates e oficinas, sempre buscando vincular esse impasse à gênese do seu Teatro do Oprimido, sistematizado nos anos 1970. Cf. "As razões deste livro: meus três encontros teatrais". In: $O$ arco íris do desejo: o método Boal de teatro e terapia. Rio de Janeiro: Civilização Brasileira, 1996, pp. 18-9. Ver ainda "Padre Batalha - A batina de sangue". In: Hamlet e o filho do padeiro: memórias imaginadas, op. cit., pp. 213-20.

${ }^{225}$ Boal, “As razões deste livro: meus três encontros teatrais". In: O arco íris do desejo, op. cit., pp. 18-9.

${ }^{226}$ Essas adjetivações de Boal passam ao largo de problemas relacionados à formalização teatral e aos modos de inserção da peça nos seus mecanismos de produção, questões já abordadas por Sérgio de Carvalho e Iná Camargo Costa, respectivamente. Cf. Costa, A hora do teatro épico no Brasil, op. cit., pp. 94-6. E Carvalho, "A peça jamais encenada". In: Folha de S. Paulo, Jornal de Resenhas, 12 ago. 2000, p. 9 (a citação encontra-se aqui).
} 
plano e confere dignidade moderna a esse momento de socialização da experiência de luta dos trabalhadores, que redefinia as relações entre o palco e o público, o texto e a representação. Esses âmbitos são atravessados por uma alteridade de classe que não detinha os meios de produção teatrais, mas cuja capacidade política de organização relativiza, historicamente, as bases de certa universalidade constituída na peça. "Então pra que é que serve fuzil que não dá tiro?", pergunta Virgílio aos “artistas sérios" da cidade. $^{227}$ A despeito da retórica de Boal, essa cena torna sensível a análise posterior de Schwarz - justamente célebre - sobre esses regimes de produção de sentido que não se estruturam de modo autônomo no pré-1964. Sem tratar em específico das montagens de Mutirão, mas considerando experiências desse tipo, Schwarz afirma:

\begin{abstract}
Num caso destes, quem seria o autor? Quem apreende? A beleza ainda adorna as classes dominantes? De onde vem ela? Com o público, mudavam os temas, os materiais, as possibilidades e a própria estrutura da produção cultural. Durante esse breve período, em que polícia e justiça não estiveram simplesmente a serviço da propriedade (notadamente em Pernambuco), as questões de uma cultura verdadeiramente democrática brotaram por todo o canto, na mais alegre incompatibilidade com as formas e o prestígio da cultura burguesa. Aliás, é difícil dar-se conta, em sua verdadeira extensão, da cumplicidade complexa, da complementariedade que muitas vezes existe entre as formas aceitas, artísticas ou culturais, e a repressão policial. $^{228}$
\end{abstract}

Nessa experimentação com as formas artísticas, estruturando-se em torno do compromisso político com um público socialmente marginal e em parte iletrado - que, até certa medida, pôde interpelar o movimento cultural a partir dos seus interesses de classe -, Schwarz valoriza o que ele chamaria de "transfusões da experiência social", uma das suas expressões diletas. Trata-se de um problema que, sob diferentes

\footnotetext{
${ }^{227}$ No dia $1^{\circ}$ de abril de 1964, segundo o relatório da Comissão Nacional da Verdade, "cinco mil lavradores armados de espingardas, enxadas, foices e facões ocuparam a cidade de Vitória de Santo Antão (berço das Ligas Camponesas) com o objetivo de criar uma resistência ao golpe militar. Durante dois dias, todos os órgãos públicos da cidade ficaram sob o comando dos líderes regionais das Ligas Camponesas, que esperaram inutilmente por armas, munições e mantimentos que seriam fornecidos pelo governador Miguel Arraes, deposto nesse dia. No terceiro dia de ocupação, as tropas das Forças Armadas, Polícia Militar e policiais do DFSP e DOPS de Pernambuco retomaram o controle e iniciaram uma caçada aos líderes do movimento". Um dos presos nessa "caçada", segundo o Diário de Pernambuco, seria o agricultor Severino Virgílio Tavares, o "Virgílio" referido por Boal. O jornal não soube informar a sua trajetória posterior a 1964. Cf. Schiaffarino, Júlia; Barros, Isabelle. "O palco que ele queria ver dividido". Diário de Pernambuco. Recife, 17 set. 2016. Disponível em: http://blogs.diariodepernambuco.com.br/documentoboal/augusto-boal/. Acesso em: 12 dez. 2018. Ver ainda Mortos e desaparecidos políticos / Comissão Nacional da Verdade. Brasília: CNV, 2014, vol. 3, pp. 146-7. Disponível em: http://cnv.memoriasreveladas.gov.br/images/pdf/relatorio/volume_3_digital.pdf. Acesso em: 20 abr. 2018 .

228 “Cultura e política, 1964-1969”, op. cit., p. 81.
} 
registros históricos e políticos, percorre quase toda a trajetória do autor, desde "Sobre O amanuense Belmiro" (1964) a "Verdade tropical: um percurso de nosso tempo" (2011). No caso do pré-1964, uma das manifestações significativas daquilo que Schwarz entenderia por "transfusões sociais" são as tentativas de aliança entre vanguarda estética e cultura popular, que se concebiam como parte e metáfora de um processo de modernização nacional que não abandonaria os pobres à sua sorte. De modo abrangente, o conceito schwarziano de "transfusões" se refere à certa dinâmica histórica em que conhecimentos acumulados sobre o país atravessam esferas compartimentadas de classe e de competência, aproximando âmbitos dissociados pela divisão técnica do trabalho, pelas especializações artísticas e, em particular, pela reposição das segregações coloniais. Para Schwarz, a possível conquista dessa reciprocidade mínima de referências entre as classes não se esgotaria numa espécie de autoesclarescimento da sociedade nacional. Essa situação em que os diferentes setores da população passam a influir um nos outros, num sentido contrário à anomia histórica promovida no corpo social brasileiro, parecia carrear um potencial político explosivo, que ultrapassaria os interesses de sobrevivência imediata do governo "populista", beneficiando-se ainda do seu momento - terminal - de radicalização. ${ }^{229}$

Num contexto de exclusão dos pobres do universo da cultura contemporânea, Schwarz aposta que essas "transfusões sociais", feitas em grande escala, contribuiriam para teorizar e formular politicamente aspectos obliterados da luta de classes no Brasil, cujas "formas mais dramáticas" costumam se travar "fora do alcance da opinião pública”, como reconheceriam os seus estudos posteriores. ${ }^{230}$

\footnotetext{
${ }^{229}$ Em 1985, por exemplo, Schwarz volta a destacar as limitações que a conjunção de classes pré-1964 teria enfrentado no "plano político", mas para afirmar que essa aliança havia sido "muito convidativa no plano da imaginação". Ao desvincular o projeto político (derrotado) e a sua elaboração estética (uma "inspiração", e "das mais vivas que temos tido"), o argumento dissocia instâncias concebidas em conjunto nas artes públicas do período, dotadas de nítida finalidade política, e nas quais a produção artística não tinha estatuto de esfera separada. O mesmo não ocorre em "Amor sem uso" (1981), que aborda esse problema, mas sob a ilusão de uma superação iminente do que o autor nomeia de "nós-com-nós dos especialistas" no Brasil. De qualquer modo, o crítico mantém fidelidade teórica ao ideal das "transfusões" críticas, como se vê nesta síntese feita já nos anos 1990: "Se formos à substância das nossas configurações culturais marcantes, aquelas em que para mal ou para bem sentimos força e universalidade, iremos verificar - acredito - que envolvem algum tipo de dessegregação, de mobilização liberadora - em geral ilusória - no campo das deformidades que assinalam a reciclagem moderna da matriz colonial. É como se apontassem o encargo histórico do país, o desastre mundial a consertar, a linha de força que confere universalidade ao provincianismo de nossa problemática interna. Quando uma espécie qualquer de superação entra em pauta, a lâmpada do interesse acende. Quando não, é a rotina de sempre". Ver "A questão da cultura" (1985). In: Lua Nova, op. cit., p. 27. Cf. "Amor sem uso". In: Novos Estudos - Cebrap, n. 1, São Paulo, dez. 1981 (editorial). E "Outra Capitu”. In: Duas meninas, op. cit., p. 135.

${ }^{230}$ Em 1976, ele afirma: "Se a experiência histórica de setores inteiros do país é atomizada e não soma, como conhecer o seu sentido? Para ficar num aspecto secundário da questão, todos emburrecemos". Cf. "Cuidado com as ideologias alienígenas" (entrevista a Gilberto Vasconcellos e Leo Wolfgang Maar). In: O pai de família, op. cit., p. 145. Ver ainda "O fio da meada". In: Que horas são?, op. cit., p. 72 (a citação está aqui).
} 
Também para o jovem Schwarz, às voltas com 1964, a separação entre pesquisa acadêmica com intenção crítica e luta política só poderia - no melhor dos casos - fazer cintilar o brilho suspeito de uma negatividade pura, que paga tributo ao lugar confinado e rarefeito concedido à cultura no país. Assim, a dissolução real e imaginária de balizas da ordem social, apenas ensaiada na cultura política da época, aparece a Schwarz como uma novidade histórica decisiva no seu retorno ao Brasil. ${ }^{231}$ De fato, essa desenvoltura diante das divisões correntes numa sociedade de classes ganha, naquele momento, uma ressonância inédita. De modo simultâneo, as "transfusões sociais" deixam entrever a hipótese de uma arte com fundamento social diverso, fazem figura de prenúncio do socialismo e fornecem um critério atual para a orientação do juízo crítico, numa possível mediação histórica para as conversões relativamente arbitrárias da intelligentsia local. ${ }^{232}$

Embora as intenções estéticas e políticas dos grupos mobilizados no pré-1964 nem sempre coincidam com as posições de Schwarz, o movimento intelectual de "ida ao povo" feito por MCP, CPCs e Arena - entre outras iniciativas sem intenção de arte, mas em busca da cultura popular enquanto elemento ativo da sociedade futura -, prometia construir um prisma objetivo por onde se avaliar o conjunto do processo cultural brasileiro. Num campo de possibilidades mais amplo, encontrava-se mesmo a hipótese de uma relação histórica menos ofuscante e subalterna com os influxos do imperialismo, dos modos de dominação oligárquicos, e das teorias e modelos sociais importados. Nesse sentido, o quadro pré-1964 também oferecia alternativa prática

\footnotetext{
${ }^{231}$ É preciso lembrar ainda que, nesse momento, os principais expoentes literários brasileiros têm posição indiferente ou mesmo dão apoio ao golpe. Após 1964, os primeiros protestos viriam de escritores considerados "menores", como Carlos Heitor Cony, além de Antonio Callado e Erico Verissimo. Schwarz reconheceria nessa omissão histórica um momento de verdade da cultura nacional: "Uma das características da relativa fraqueza da vida literária e intelectual brasileira é que quase não tenha havido intelectuais ou escritores de grande porte que tenham julgado interessante tomar uma posição elaborada e pública em relação ao que aconteceu no Brasil depois de 1964. O fato de escritores com grande capital literário como o João Cabral de Melo Neto, o Guimarães Rosa etc., não terem achado que sua envergadura intelectual os obrigava a falar nisso, certamente caracteriza de maneira muito negativa a cultura brasileira". Cf. entrevista a Gildo Marçal Brandão e O. C. Louzada Filho. In: Encontros com a Civilização Brasileira. Rio de Janeiro, set. 1979, n. 15, pp. 97-112.

${ }^{232}$ Diz Schwarz: "Quando eu era estudante de ciências sociais na USP, acontecia mais ou menos o seguinte: alguns professores eram positivistas, outros eram weberianos, outros ainda marxistas, que por sua vez se dividiam em lukacsianos e althusserianos, depois gramscianos, e assim por diante. Essas filiações em parte refletiam simpatias filosóficas, em parte políticas, em parte os altos e baixos das reputações internacionais; mas não refletiam o aprofundamento de questões efetivamente em jogo. Pouco depois esse quadro começou a mudar, por influência talvez da radicalização do pré-1964. Passava a ser menos importante ser isso ou aquilo do que avançar um passo em relação aos problemas que estavam sendo postos com insistência crescente pela realidade, que ia corrigindo e criticando os esquemas dos meus professores". "Sobre a Formação da literatura brasileira". In: Sequências brasileiras, op. cit., p. 20.
} 
para os "impasses de intelectual pequeno-burguês", segundo os termos de Schwarz. Ainda referindo-se a esse momento histórico de "ida ao povo", ele afirma:

São experiências que mudam a substância do processo artístico e do processo crítico, se você acompanha e participa. Para mim, isso foi uma espécie de micromodelo do que era possível. De repente, você mobiliza os seus recursos em favor, e em presença, de uma outra classe social. Por um lado, você supõe que está ajudando, o que pode não ser verdade. Mas eles te ajudam muitíssimo a transcender os seus problemas de sair do teatro, sair do universo cultural mercantil. (...) O Arena, por exemplo, era bem sucedido do ponto de vista econômico, em São Paulo. E produzia para um público de classe média. De repente, via a possibilidade de fazer uma coisa sem bilheteria, financiada pelo Estado e de alta relevância social. E que, sobretudo, soluciona todos os seus impasses de intelectual pequenoburguês, digamos. Isso é uma coisa que me impressionou vivamente. ${ }^{233}$

Esse anseio de vinculação eficaz entre o vir a ser da sua crítica e a centralidade político-produtiva das camadas subalternas supõe, entre outros aspectos, a simbiose entre produção de conhecimento e interesse material, que - para o jovem Schwarz teria um caráter por definição "subversivo". ${ }^{234}$ Nos seus termos, tratava-se de colocar "os seus conhecimentos e preparo cultural a serviço da luta dos despossuídos", de modo a redirecionar a "cultura burguesa contra o seu fundamento de privilégio". 235 De fato, até o corte promovido pelo AI-5 e pelo seu exílio, o raciocínio crítico de Schwarz opera - de modo tácito ou aberto - com essa possibilidade prática de passar ao outro lado da guerra de classes brasileira, e isso incluía um esforço de desprenderse de interesses da sua classe de origem. É essa a vaga de pressões contraditórias que, nesse momento, atravessa o lugar social do autor. Nos anos 1960, Schwarz cogitava mesmo se tornar professor de ensino secundário no interior do Brasil, caso viesse a revolução. Ele dizia aos amigos que, num eventual processo de expropriação coletiva dos meios de produção, o ideal seria assumir uma "profissão útil à população", abandonando a veleidade de "pontificar como intelectual" na academia. Para justificar

\footnotetext{
${ }^{233}$ Entrevista ao autor, op. cit.

${ }^{234}$ No editorial de estreia da revista Teoria e Prática, redigido por Schwarz, afirma-se: “A conjugação de interesse e raciocínio é subversiva, tanto para a objetividade acadêmica, desinteressada e desinteressante, quanto para os interesses vigentes, incompatíveis com o raciocínio crítico. (...) Os que não sabem ou não costumam ler não serão, naturalmente, nossos leitores, mas são a nossa referência: definem limite, situação e tarefa da palavra escrita, que se não sabe deles não sabe de si nem serve". Cf. "Apresentação". In: Teoria e Prática. São Paulo, 1967, n. 1, p. 1.

235 “Nunca fomos tão engajados”. In: Sequências brasileiras, op. cit., p. 172.
} 
essa deserção de classe, recorria à experiência recente da Revolução Cubana. ${ }^{236}$ Para ele, a vitória da guerrilha reafirma o socialismo enquanto tendência histórica visível, dessa vez em solo latino-americano, mas a revolução não seria implementada em prol de "liberdades intelectuais", o que não a tornava menos necessária. ${ }^{237}$

De qualquer modo, além da aspiração à efetividade do pensamento crítico, o que se entrevê - nessa imagem antecipatória do seu salto a outro campo social - é uma perspectiva histórica que se temporaliza a partir desse porvir iminente, radicalmente não-experimentado, sob a proximidade imaginativa da revolução. Nessa espera schwarziana, saturada de expectativas, o futuro assumia por vezes um caráter de evidência progressista. E isso nutre um modo específico de subjetivação, inscrito nessa dinâmica histórica orientada e cumulativa (que, até o golpe, era tensionada pela hipótese real de superação do subdesenvolvimento). Entre 1964 e 1968, acentua-se e se redefine o descompasso entre essa temporalidade progressista e a matéria histórica brasileira. Dito de modo breve, essa percepção social do tempo, marcada por um crescendo progressivo e acelerado, e que se quer apoiado no conflito e na consciência coletiva, coexiste - no interior das categorias do crítico - com a verificação de um presente que parece enredado numa reprodução ampliada de si mesmo. Ou seja, em que não vigora o momento forte e dialético de crise, que o autor relaciona ao "desdobramento realista da vida", no qual a "situação engendra a situação e a última refaz as anteriores". ${ }^{238}$ Ao mesmo tempo, no pós-golpe, apresenta-se um equivalente político que parecia responder - de modo parcial e bastante precário - a esses dois registros histórico-conceituais incongruentes, que se repelem mutuamente na crítica de Schwarz. São as vanguardas de propaganda armada da revolução e de resistência à ditadura, que teriam a adesão do autor em 1968 (o problema será retomado adiante).

Por ora, cabe destacar o modo como Schwarz recapitula essa passagem entre a sua experiência intelectual pré-1964 - ele pensa, sobretudo, na estadia em Yale - e o

\footnotetext{
${ }^{236}$ Para uma amostra da energia histórica liberada pela Revolução Cubana, e o seu modo inicial de irradiação nos círculos intelectuais, cf. Sartre, Jean-Paul. Furacão sobre Cuba. Rio de Janeiro: Editora do Autor, 1960.

237 “Eu já tinha a noção de que em Cuba havia repressão à vida intelectual. Então, havia a questão de como você se situa em relação a isso. Aceita, não aceita, vai embora... E, eu dizia: 'Olha, a revolução é uma coisa tão importante, melhora tanto a vida da população, que tem que ficar a favor'. Agora, se você começar a pontificar como intelectual, vai dar errado. Você vai em cana logo, porque não é 'liberdade intelectual'. Uma saída é ser professor do secundário. Você vai para o interior, e fica lá fazendo as suas obras completas, quietinho. E assume uma profissão útil à população", afirma Schwarz. Entrevista ao autor, op. cit.
}

${ }^{238}$ Cf. a introdução de "Uma barata é uma barata é uma barata”. In: A Sereia e o desconfiado, op. cit., p. 59. 
engajamento às voltas com o golpe de Estado. Diz ele: "A política começou a tomar conta e eu desenlouqueci do lado acadêmico e enlouqueci do outro". ${ }^{239}$ Esse aparente salto entre extremos, porém, possui racionalidade própria. Como visto anteriormente, entre 1958 e 1961 - em meio a inúmeras variações nos juízos críticos -, o ensaio de Schwarz supõe uma referência comum à noção de obra autônoma como instância congenial à crítica dialética. ${ }^{240}$ Nesses termos, a análise dialética parecia concebível apenas a partir de narrativas relativamente integradas em si mesmas, dotadas de coerência construtiva interna, sob a "imanência estrita das significações", aspecto que o crítico entendia estar radicado no "ato humano" e no curso lógico da "História", que se desdobra de um conflito presente até certa dimensão própria de futuro. ${ }^{241} \mathrm{Na}$ sua primeira crítica, as manifestações literárias que, por algum motivo, não se prendem a esse sentido "imanente" de "História" tendem a aparecer como falha. E essa ideia de obra inteiramente consistente, na qual os problemas esteticamente formalizados se renovam e se refazem a cada estágio cumprido, sob o imperativo da moderna racionalização artística, aludia às promessas de integração social da industrialização brasileira. Essa era, afinal, a base material que parecia capaz de revolver e racionalizar o todo anômico brasileiro, configurando a força de trabalho "abstrata" e desobstruindo os enquadramentos antissociais repostos desde o jugo colonial, em benefício de uma modernização nacional e popular.

O fiasco de 1964, porém, impele o autor a perspectivar melhor os modos de inserção social da sua atividade crítica, sem que seja suprimido o quadro de inteligibilidade estética e histórica anterior. Sob a gestão diretamente policial-militar dos impasses do capitalismo brasileiro, a postulação de uma indissociabilidade entre a razão e o fechamento relativo da autonomia estética, adotada até ali como horizonte inultrapassável para a intervenção crítica, aparece como um limite político. E, de fato, Schwarz tenta construir uma unidade difícil - e insubsistente - entre as suas premissas teóricas e o impulso de interferência direta na realidade brasileira. Assim, alteram-se os resultados do seu ensaio crítico. Ao mesmo tempo em que os contrastes

\footnotetext{
239 "A dialética envenenada de Roberto Schwarz", op. cit., pp. 64-8.

${ }^{240}$ Isso se enuncia de modo direto, por exemplo, em "A Letra Escarlata e o Puritanismo". In: A Sereia e o desconfiado, op. cit., p. 133. Para uma discussão teórica mais ampla sobre esse problema, feita a partir da obra de Brecht, e considerando a situação brasileira, ver Pasta, José Antonio. "Brecht/Brasil/1997 (vinte anos depois)". In: Benjamin, Walter. Ensaios sobre Brecht. São Paulo: Boitempo, 2017, pp. 137-9.

241 “Emília Galotti e o nascimento do Realismo". In: A Sereia e o desconfiado, op. cit., p. 118 e 126.
} 
rebarbativos e estridentes dessa matéria social the parecem repostos num estágio aquém da sua contradição interna, Schwarz busca conceituar o que ele entendia ser, afinal, uma temporalidade diferente, que ainda não indicia integração progressiva dos contrários, acumulação reparadora, desenvolvimento ascendente, etc. "Nada leva a nada", escreve o autor em 1964, e "nem a cultura garante lucidez, nem a floresta de contradições produz um conflito". ${ }^{242}$ É bem verdade que esses apontamentos sobre o Brasil não assumem a primazia teórico-interpretativa nos seus ensaios anteriores a 1968. No entanto, tal sentimento das coisas serve à sua primeira "imagem original" do país, ${ }^{243}$ que será discutida nas páginas seguintes.

242 "Sobre O amanuense Belmiro". In: Civilização Brasileira, 1966, n. 8, p. 166.

${ }^{243}$ Essa passagem schwarziana, que aparece no seu ensaio "Sobre O amanuense Belmiro" (1964), foi descrita pela primeira vez por Paulo Arantes. Cf. Sentimento da dialética, op. cit., pp. 55-7. 
Capítulo III

\section{Desejo de intervenção e cultura confinada}

\section{O amanuense Belmiro: uma imagem de Brasil}

Cinco anos após o seu artigo de estreia sobre a prosa de Cyro dos Anjos, e sob o impacto de 1964, Schwarz reexamina O amanuense Belmiro (1937). Dessa vez, ele reconhece de saída que a sempre citada sobriedade narrativa do livro, tratada em geral isoladamente, configura a sua mais saliente aparência sensível. Como visto anteriormente, em "Tempo de ficar velho", a "transparência" prosaica desse romance servia a uma "multiplicidade" de mediações, segundo o crítico. Agora essa dicção "clara" apresenta também uma contraface de "facilidade e rapidez". ${ }^{244}$ Segundo Schwarz, o discurso se escora na "familiaridade" dos temas configurados. Há uma profusão de imagens imediatas que dispensam explicação, transcorrendo com desenvoltura em meio à vida inerte, que compõe a sua matéria. O ensaio se propõe, então, a desdobrar o sentido desse andamento nítido e, ao mesmo tempo, algo "levitado". Desse modo, a tenuidade da prosa, que evoca com "graça" a presença do objeto, não é refutada a priori como descompromisso com a "História" nem como estilização pessoal ou "psicologista". A frase lépida torna-se um momento constitutivo do possível teor de verdade desse romance.

A percepção de um "recurso amenizador" na prosa de Cyro dos Anjos não era uma novidade na sua fortuna crítica. O reconhecimento dessa característica formal

\footnotetext{
${ }^{244}$ Esse ensaio foi elaborado sob encomenda para uma nova edição do Amanuense e, posteriormente, vetado pelo autor. "O editor, que era amigo do Cyro dos Anjos, levou para ele dar o visto. O Cyro leu e disse: 'É um trabalho interessante, mas eu prefiro que não saia", diz Schwarz. "Sobre O amanuense Belmiro". In: Revista Civilização Brasileira. Rio de Janeiro, 1966, n. 7, p. 161. Cf. “Tira-dúvidas com Roberto Schwarz”, op. cit., p. 58.
} 
vinha desde o "rodapé" pioneiro de Antonio Candido - sob o enfoque de um “equilíbrio" entre análise e lirismo -, e aparece na leitura de Schwarz feita em 1959, atrelada a um suposto processo de autoconhecimento da voz narradora. Em "Sobre $O$ amanuense Belmiro", contudo, Schwarz tenta sondar na "leveza" mesma dessa prosa o seu próprio termo de comparação. Para isso, a lepidez narrativa deve engendrar a sua negação constitutiva, a passagem a partir da qual se poderia entrever a determinação limitante do objeto, submetido, então, à prova da sua contradição. Dada essa desarticulação progressiva e orientada, cada momento dessa análise carregaria em si a estrutura do "todo", constantemente redefinido em razão das novas correlações internas. Em outros termos, cada passo da argumentação adquire um "sentido funcional não passível de ser isolado", como ensinava José Arthur Giannotti a partir d'O Capital. $^{245} \mathrm{Na}$ exposição desse encadeamento lógico, a negação suprimida da evocação lírica mostra o módulo fundamental de construção - nomeado pelo crítico como a "mistura belmiriana" -, que redimensiona o ponto de partida. Como se verá adiante, o crítico acolhe parcialmente a sua empiria como praxis objetivada na forma. E, a partir dessa tentativa de crítica imanente, Schwarz busca erigir as suas categorias analíticas, que visam tornar inteligível a particularidade do processo social configurado na obra, e explicam-se por meio dele. ${ }^{246}$

Nesse sentido, o seu primeiro passo lógico-conceitual é o reconhecimento de que existe método nessa ligeireza narrativa. Não era algo evidente para o jovem Schwarz. Isso porque essa obra, diferentemente das minuciosas configurações intermediárias da situação histórica no realismo europeu, sistematicamente "constata,

\footnotetext{
${ }^{245}$ Nesse esquema de inteligibilidade, considerações unilaterais da fortuna crítica - involuntariamente objetivadas nas análises - "podem ser recuperadas se forem capazes de adquirir um sentido propriamente dialético" no interior do ensaio, o que comprovaria a abrangência própria da crítica materialista. No caso da recepção ao Amanuense, fez carreira a nostalgia de um espaço alógico, submetido aos arrancos espiritualizantes do arcaico e do incubado, à qual a especificação do "lírico" neste ensaio não deixa de remeter. Para citar apenas um exemplo, Ivan Ribeiro afirmava em 1937 que a "verdade é que a história de Belmiro independe da circunstância 'amanuense'. Ele poderia ser um médico, um advogado, um empregado de banco, porque o que mais importa realmente não é a fração burocrática de Belmiro na Seção de Fomento, e sim o Belmiro meio boêmio, nostálgico das auroras e dos crepúsculos de Vila Caraíba". A íntegra desse artigo foi reproduzido por Nobile, Ana Paula Franco. A recepção crítica de $\mathrm{O}$ amanuense Belmiro, de Cyro dos Anjos (1937), op. cit., pp. 157-9. Para a referência teórica desta nota, ver Giannotti, José Arthur. "Notas para uma análise metodológica de O Capital". In: Revista Brasiliense. São Paulo, Brasiliense, 1960, n. 29, p. 70.

${ }^{246}$ Segundo a lição metodológica de Lukács, referenciado na lógica hegeliana, "quando somos confrontados com o objeto imediatamente dado, temos de nos 'comportar de maneira igualmente imediata e receptiva, isto é, nada mudar em sua maneira de apresentar-se'. A única maneira de sair desse imediatismo é pela gênese, pela 'produção' do objeto. No entanto, isso pressupõe que as formas de mediação nas quais e pelas quais é possível sair do imediatismo da existência dos objetos dados são mostradas como princípios estruturais e como tendência reais do movimento dos próprios objetos". Evidentemente, o pressuposto teórico de Lukács é de que ainda se possa falar numa "essência dialética da realidade", segundo a sua terminologia. Cf. Lukács, História e consciência de classe: estudos sobre a dialética marxista, op. cit., pp. 318-20 e 330-1 (grifos do autor).
} 
e descarta o que não prevaleceu", sem a "medida do que não foi". ${ }^{247}$ Do "brilho rural" ao abrigo na burocracia, as linhas que descrevem a trajetória de Belmiro "não poderiam ser (...) menos definidoras", admite Schwarz. Há sempre o mesmo tom amaneirado, ainda quando a prosa configura objetivamente problemas. Nas análises anteriores a 1964, viu-se os procedimentos adotados por Schwarz em relação a essas situações narrativas. Ele retém e estuda, de modo pormenorizado e em suas diferentes manifestações, a não relação entre o "pormenor submetido a leis e a totalidade contingente". ${ }^{248} \mathrm{E}$ verifica, em termos gerais, que aqui a "História" não vige. Nesse percurso, alguns elementos significativos das obras são reconhecidos com perspicácia crítica, mas não se integram num conceito historicamente mediado. Já no comentário sobre o Amanuense, a particularidade "lírica" de Belmiro configura-se desde o início como momento de uma diferença determinada, o que lhe dá um sentido estéticosocial delimitado, e flagra a relevância não-evidente dessa matéria local.

Para Schwarz, o "fraternalismo sentimental" da prosa belmiriana - a sua promiscuidade "democrática" que "festeja a todos cordial e indistintamente" apresenta uma homologia estrutural com certa "sensibilidade populista". ${ }^{249}$ Defendendo a racionalidade própria desse resultado formal, o empuxe absoluto da prosa "não é negado abstratamente, mas compreendido em sua figura histórica concreta, como momento do próprio processo". ${ }^{250} \mathrm{Ou}$ seja, enquanto estruturação formal de um modo contraditório e particular de reprodução social. De fato, o crítico situa a categoria do lírico no seu tempo histórico presente, marcado pelo término da legitimação política dos compromissos de classe populistas. Por sua vez, isso se torna um critério interno de objetividade na obra. "A presteza da prosa não reflete, compensa o peso da experiência real", diz Schwarz. ${ }^{251}$ Sob essa dinâmica belmiriana de indistinção, sem transformação orientada, a tese anterior sobre a "multiplicidade" progressiva da narrativa de Cyro dos Anjos se repõe em sua unilateralidade enigmática, que pede decifração crítica.

\footnotetext{
247 "Sobre O amanuense Belmiro", op. cit., p. 163.

${ }^{248}$ Lukács, História e consciência de classe, op. cit., p. 218 e 226.

249 “Sobre O amanuense Belmiro", op. cit., p. 164.

${ }^{250}$ Lukács, História e consciência de classe, op. cit., p. 375.

251 “Sobre O amanuense Belmiro", op. cit., p. 164.
} 
Desse modo, o ensaio de Schwarz abre-se, de fato, para a construção de determinações abstratas, desde um ponto de vista materialista. A partir do conceito de "mistura belmiriana", a imagem do Brasil surge enquanto resultado históricocategorial no seu ensaísmo. Essa "mistura belmiriana", lei específica da composição do livro, remete à coexistência entre ideias "inconciliáveis" no Amanuense. A enumeração schwarziana é bastante conhecida. Em Belmiro conviveriam o “democratismo e o privilégio, o racionalismo e o apego à tradição, o impulso confessional, que exige veracidade, e o temor à luz clara". ${ }^{252}$ Em termos gerais, a adequação das relações sociais ao princípio de racionalização, baseado no cálculo de meios e fins, junta-se de modo funcional e estruturante a uma lógica dominada pela não estabilização da regra. Nesse ensaio, Schwarz atribui a duplicidade constitutiva dessa passagem "do mesmo ao mesmo", cujo fundamento é a reposição do "atraso" colonial pela atualidade capitalista, à "perspectiva intermediária do burocrata". Esse lugar social "incerto" encarnaria, na obra, a ausência de rupturas entre a cidade e a fazenda. Dada essa indiscernibilidade prática entre o passado e o presente, marcada pela reintrodução do privilégio e do favor numa urbanização sem traços cortantes, a forma do Amanuense torna-se "lírica". E não se incorpora assim o elemento “dramático", enquanto possível senso de conflito na obra. ${ }^{253}$

Sob certa medida, cujos limites serão discutidos adiante, surge aqui a "visão da conexão entre o desdobramento do objeto e o desdobramento das categorias" tomando de empréstimos os termos de Peter Bürger -, num esforço de historicização dos instrumentos críticos. ${ }^{254}$ Para Schwarz, as oscilações líricas dessa enviesada alma sensível, que na sua matriz europeia resultou por vezes numa vindicação ativa da diferença - supondo a igualdade-a-si-mesmo na esfera subjetiva -, torna-se aqui "penhor de conformismo", sustentando uma inconclusiva "estética de acomodação" dos opostos. Assim, o princípio de autenticidade da bela alma local associa-se antes

\footnotetext{
${ }^{252}$ Ibidem, p. 169.

${ }^{253}$ A seu modo, Schwarz buscaria também demonstrar como o "universal", desde que cavado na particularidade, "pode fazer parte da realidade sem que com isso tombemos no idealismo ou no empirismo". E nesse aspecto, antecipando o ensaio clássico de Giannotti, mantém igual distância do "vivido" existencialista, dos modelos estruturalistas e da epistemologia althusseriana, que, "cada um à sua maneira, trazem a História para a égide do psicologismo". Trata-se de recusar, pela via própria da configuração literária, o corte seco entre experiência e significação, ou entre "objeto real" e "objeto de conhecimento", segundo a linguagem althusseriana. As expressões entre aspas são de Giannotti, José Arthur. "Contra Althusser". In: Exercícios de filosofia. Petrópolis, Rio de Janeiro: Vozes, 1980, p. 101.

${ }^{254}$ Bürger, Peter. "A historicidade das categorias estéticas”. In: Teoria da vanguarda. São Paulo: Cosac Naify, 2008, p. 46.
} 
ao decoro da "aparência tradicional", e não à possível procura da verdade no confronto com o seu objeto. Como reconhece o crítico, para uma personagem que acede ao cargo de amanuense por indicação de um deputado, a dimensão das "abstrações institucionais" - vinculada ao esquema objetivo de tarefas e contraprestações entre o "eu" e o mundo -, bem como a noção de carreira aberta ao talento, só podem soar como "falta de naturalidade". Daí que a "sensibilidade vira sensitiva e se reduz a pedir que não machuquem", nos termos de Schwarz. ${ }^{255}$ Mesmo a fidelidade ao existente não se afirma como "questão ética", no sentido da coerência cortante de uma individuação, "mas de cautela - pois esta parece 'a única estrada possível'”, segundo Schwarz. ${ }^{256}$

Sob essa reorientação no ponto de vista crítico, Schwarz vê novamente proliferar na matéria local uma miríade de contradições que não expressam antagonismos nitidamente configurados. "Nada leva a nada - é este o horror do livro", afirma ele. ${ }^{257}$ Contudo, é na discussão sobre o problema da distância estética que esse ensaio expõe os seus aspectos mais decisivos. Em primeiro lugar, nesse momento Schwarz ainda se questiona sobre a pertinência formal - e o alcance críticorepresentativo - de romances em que o ponto de vista da personagem se configure como "instância última da realidade". ${ }^{258}$ No caso do Amanuense, ele afirma que a diferença entre a "cegueira profilática de Belmiro" e o "nosso (modo) de vê-lo vendo" surge como algo "suficientemente insuficiente". ${ }^{259}$ No entanto, como a narrativa seria concebida em forma de diário, as "frequentes platitudes de seu herói e pseudo-autor não são defeito, embora sejam limite", afirma o crítico. "O que seria falha em terceira pessoa narrativa, em primeira pessoa do singular é caracterização", segundo ele. ${ }^{260}$ Isso não o impede de assinalar que, diferentemente do anteparo irônico de um Machado de Assis, a prosa de Cyro dos Anjos "mal se distingue do conformismo

\footnotetext{
255 "Sobre $O$ amanuense Belmiro", op. cit., p. 165.

${ }^{256}$ Ibidem, p. 166 (grifos do autor).

257 "Sobre $O$ amanuense Belmiro", op. cit., p. 166.

${ }^{258}$ Esse seria o caso de Henry James. Num ensaio de 1963, Schwarz via nessa prosa uma "concentração no que é secundário", desvio que tende à "coreografia" e não ao esforço de "compreensão" do objeto. Cf. "Retrato de uma Senhora (o método de Henry James). In: A Sereia e o desconfiado, op. cit., pp. 161-2.
}

\footnotetext{
${ }^{259}$ Schwarz marca a diferença em relação ao seu ponto de vista anterior sobre Cyro dos Anjos desde o pórtico do ensaio. E escolhe, para isso, uma epígrafe adorniana: "Grandes obras são aquelas que têm sorte em seus pontos mais duvidosos". "Sobre $O$ amanuense Belmiro", op. cit., p. 161.

${ }^{260}$ Ibidem, p. 164.
} 
simples". Reavaliando os termos de Antonio Candido, Schwarz fala em "equilíbrio difícil" da narrativa:

(...) o detalhe social das evocações é suficiente para complicar a nostalgia do amanuense, para fazê-la concreta, mais que mera lamentação da juventude que passou; e é suficientemente insuficiente para evidenciar as limitações de Belmiro. Noutras palavras, o que Belmiro diz é bastante para concretizar-lhe a figura e para prová-lo limitado, para permitir, embora não force, uma leitura que transcenda o seu ponto de vista e o tenha por tema. ${ }^{261}$

Esse trecho citado exemplifica bem como o ensaio sobre $O$ amanuense Belmiro aponta para um momento ambivalente de transição crítica. Nele, coexistem pressupostos do Schwarz pré-1964 e uma manifestação ainda vacilante e parcial do seu esquema crítico maduro. Schwarz apreende, de fato, antagonismos históricosociais sedimentados - e amortecidos - nessa estrutura formal. Contudo, embora o problema do valor estético encontre-se em parte sob a tutela da história, o crítico vincula a percepção de uma "mistura belmiriana" à ideia de que a positivação existente na obra - o seu "esforço consciente de preservar a graça a despeito da vida" - teria impedido no mundo narrado o pleno desdobramento "realista" dos contrários (entendido na sua acepção anterior). ${ }^{262}$

Em outros termos, nessa circulação "desordenada" entre cotidiano e memória, as configurações sociais no Amanuense não formariam um "sistema autônomo", segundo Schwarz. ${ }^{263}$ Assim, em tese, a obra perderia a possibilidade de representação do presente como história. O crítico se incomoda, sobretudo, com a "precedência da biografia sobre o mundo, que está para servi-la". ${ }^{264}$ Nos seus comentários sobre o abafamento real das contradições no Amanuense, ele não considera inteiramente a hipótese de que esse todo só possa ser representado e compreendido negativamente, por esfacelamento (o que não é, sem dúvida, o caso de Cyro dos Anjos). Além disso, num momento histórico em que ainda parecia vigorar uma incoerência heurística no

\footnotetext{
261 "Sobre O amanuense Belmiro", op. cit., p. 167.

${ }^{262}$ Ibidem, p. 162.

${ }^{263}$ Ibidem, p. 166.

264 “Sobre O amanuense Belmiro", op. cit., pp. 167-8.
} 
atrito entre discurso e prática - que Schwarz faz ver por meio da análise do narrador -, esse ensaio preserva o fundo falso da ordem liberal-burguesa, promovendo uma verificação parcial da sua realização particular. O seu eixo de interpretação se limita ao desconjuntamento nacional, sob o baque de 1964. No entanto, vale destacar que Schwarz chega a sugerir o possível passo seguinte da sua análise: "Resta entretanto completar a imagem, para que o mal de Belmiro não pareça mera inércia. (...) É preciso questionar também a cidade: embora seja razão em face da fazenda, ela não é razão em si mesma”. ${ }^{265}$

Em resumo, não se trata aqui do reconhecimento avant la lettre da "forma objetiva" ou da "redução estrutural" na obra, noção que orientaria os trabalhos machadianos de Schwarz. ${ }^{266}$ Contudo, o crítico se aproxima da tangibilidade histórica do seu objeto, apreendendo um modo particular de configuração dessa temporalidade social diversa. Schwarz reconhece que a passagem do tempo no Amanuense configura-se como registro insistente e mesmo "obsessivo". No entanto, trata-se de uma presença palpável $e$ fantasmagórica, que "deve a força ao que não produziu". ${ }^{267}$ Para o crítico, o "movimento atmosférico da memória e da divagação" governa indevidamente a forma, comprometendo a representação da variabilidade do pormenor realista. Ocorre que essa "subjetivação" temporal seria o sintoma de um ritmo histórico-social específico, que nasce da reincidente "experiência do que não vem a ser". ${ }^{268}$ A figuração da "imobilidade" e a dicção "lépida", determinados reciprocamente, redefinem-se enquanto "forma negativa de conciliação", perspectiva que teria se sedimentado estruturalmente nessa obra. Para Schwarz, "mais do que crise", o que se afirma em $O$ amanuense Belmiro é a "decomposição do presente". ${ }^{269}$

\footnotetext{
265 “Sobre $O$ amanuense Belmiro", op. cit., p. 169.

${ }^{266}$ Nesse sentido, o acontecimento decisivo será mesmo a publicação em 1970 de "Dialética da Malandragem", de Antonio Candido. Para o seu conceito de "redução estrutural", ver também "De cortiço a cortiço" (1973). In: $O$ discurso e cidade. Rio de Janeiro: Ouro sobre Azul, 2010, pp. 107-132.

267 “Sobre $O$ amanuense Belmiro", op. cit., p. 170.

${ }^{268}$ Ibidem, p. 170.

${ }^{269}$ Ibidem, p. 170.
} 


\section{Os fuzis: explosão da forma}

No item anterior, viu-se como o estudo "Sobre O amanuense Belmiro" (1964) avança na definição de incongruências da sua matéria histórica. Ao mesmo tempo, os procedimentos críticos de Schwarz não se integram, nesse ensaio, ao "primado da política" que ele reconhecia como o aspecto decisivo na experiência brasileira da época. E isso ocorre por vários motivos. Como visto, no texto sobre Cyro dos Anjos, a crítica de certa lógica social constituída por dualidades que se desautorizam reciprocamente - que assume aqui aspecto de caracterização nacional - elabora-se sob a expectativa de um "desdobramento realista" dos contrários, referindo-se, assim, a certo curso lógico da "História" que seria "imanente" à problemática da obra cerrada, inteiramente consistente em si (um postulado discutido no primeiro capítulo da tese). No pós-golpe, sob o acirramento e a implementação de novos expedientes de exceção como paradigma de governo, qual o equivalente prático-político possível para uma perspectiva teórica como essa? Nos termos do ensaio, a resolução desse problema seria como traçar a quadratura do círculo. Isso porque a ambivalência social que a noção de "mistura belmiriana" apreende no plano do objeto, identificado com argúcia por Schwarz, repercute - em parte - sobre o próprio ponto de vista do crítico. No conceito-chave desse texto, colidem-se - de modo irresolvido - categorias utilizadas nos seus escritos entre 1958 e 1961 e notações próprias sobre o Brasil, que iriam constituir um sistema na obra madura do autor.

Essa hesitação crítica de Schwarz também remete às indefinições políticas que, no imediato pós-golpe, incidem diretamente sobre o seu lugar social. Apesar do desnorteio amplo e persistente de 1964, a expectativa inicial de repressão violenta, e a sensação de medo correspondente, são gradualmente dissipadas na rua Maria Antônia. Cerca de dois meses após o golpe, segundo Schwarz, a vida acadêmica parecia ter "retomado" o seu curso normal. ${ }^{270}$ Como se sabe, não faltam na USP arbitrariedades desde o primeiro ano da ditadura, como os famigerados Inquéritos Policiais Militares (IPMs), com a oitiva de catedráticos e a ameaça a professores e alunos. ${ }^{271}$ No entanto, o grosso do terror seria reservado aos movimentos populares. "A gente voltou aos

\footnotetext{
${ }^{270}$ Entrevista ao autor, op. cit.

${ }^{271}$ Ver o relatório final da Comissão da Verdade da Universidade de São Paulo (2018), em particular o volume 7 ("Faculdade de Filosofia, Letras e Ciências Humanas, IPM e professores cassados"). Disponível em: https://sites.usp.br/comissaodaverdade/relatorio-final/. Acesso em: 11 jan. 2019.
} 
seminários sobre Marx. Os grupos de esquerda voltaram a fazer a subversão modesta, aqui e ali. E o teatro voltou, com grande flama", afirma Schwarz. ${ }^{272}$ Nos primeiros meses após a queda de Goulart, circulam à esquerda previsões de que o $1^{\circ}$ de Abril seria mera "quartelada" militar, condicionada por fatores externos, e sem bases sociais consistentes. O regime estaria, portanto, suscetível à queda em curto prazo. ${ }^{273}$ Além disso, setores políticos "liberais" nutriam esperanças de eleições diretas e do "retorno dos civis". Sob esse cenário confuso, formulam-se as teses de Schwarz sobre $O$ amanuense Belmiro, que refratam - a seu modo - o momento em que o progressismo social uspiano dá os primeiros passos na tentativa de decifrar a experiência "populista" de conciliação de classes e os sentidos político-econômicos da contrarrevolução preventiva em curso, que não eram evidentes.

Na prática, desde o momento em que Schwarz regressa ao Brasil, em maio de 1963 - às portas da revolução que não houve -, o microcosmo de esquerda da Maria Antônia lhe parecia "muito politizado e, ao mesmo tempo, muito despolitizado". ${ }^{274} \mathrm{O}$ autor costuma lembrar como a primeira experiência na Faculdade de Filosofia, entre 1957 e 1961, havia lhe servido como um "banho de Brasil", com a presença de "colegas do interior, de todas as classes, com toda ordem de preocupações", ${ }^{275}$ e sob discussão política “dia e noite". Para ele, essa composição de classes mais variada e o seu ambiente "neopolítico" diferiam, de modo significativo, da sua trajetória pessoal e familiar anterior, circunscrita a um clima espiritual "muito vienense". ${ }^{276}$ Ao mesmo tempo, o marxismo uspiano - movido pela ambição de construir uma leitura original e

\footnotetext{
${ }^{272}$ Entrevista ao autor, op. cit.

${ }^{273}$ Um dos primeiros acertos teóricos sobre 1964, e que refuta essas teses, é elaborado por Ruy Mauro Marini. Num ensaio publicado originalmente no exterior, em abril de 1965, Marini nomeia a "contrarrevolução" em curso, e insiste que a ditadura tinha também raízes locais, endógenas, e que - conforme ele acreditava - iria produzir o seu contrário, que era a revolução socialista. No entanto, Marini ainda fala num regime "bonapartista" - de arbitragem de classes -, baseando-se na experiência histórica europeia, de modo a sinalizar que os grupos industrial e agráriocomercial no Brasil não se sentiam suficientemente fortes para assegurar o poder, exigindo-se uma solução pelo alto. Cf. "Contradições e conflitos no Brasil contemporâneo". Teoria e Prática. São Paulo, 1968, n. 3, pp. 25-52.

${ }^{274}$ Entrevista ao autor, op. cit.

275 “A dialética envenenada de Roberto Schwarz”, op. cit., pp. 64-8.

276 “A vida europeia dos meus pais foi cortada pela guerra. Eles custaram a fazer uma roda no Brasil, de modo que fiquei sem o ambiente que normalmente teria numa situação mais integrada", diz Schwarz. Nos espaços sociais que ele frequenta - sobretudo, os seus dois colégios particulares, o Mackenzie e o Rio Branco - o "Brasil mais característico" não se fazia presente, ou "comparecia de um jeito que eu não era capaz de identificar", segundo os termos do autor. Para uma síntese biográfica de Schwarz, ver Werneck, Humberto. "Roberto Schwarz: um intelectual com as ideias no lugar". In: Jornal do Brasil. Ideias/Livros, 29 dez. 1990, p. 8. E também "O olhar de fora do lugar: estranhezas do vienense brasileiro". In: Veja. São Paulo, 22 ago. 1990, p. 102 (texto não-assinado). As citações estão em "Roberto Schwarz". In: Retrato de grupo, op. cit., pp. 227-8; e entrevista ao autor, op. cit.
} 
não-dogmática sobre o Brasil, e que lhe abria portas - avançava "num mundo à parte", e "pouco sofria o confronto das correlações de força reais, pelas quais tínhamos franca antipatia”, nos termos do autor. ${ }^{277}$ Mesmo na iminência do golpe de Estado, diz Schwarz, a maioria dos seus colegas de faculdade mantinha "aversão à política real". "Nós tínhamos 'temas' de teoria política, de teoria social. Todos éramos antiimperialistas. Mas a política nos era muito estranha. Muito estranha, mesmo”, afirma. "Aí em 1964 é que nós tomamos uma ducha fria". 278

Também a crítica de Schwarz, como se vê, não assimila esse golpe de imediato. Em 1966, porém, ocorre uma inflexão importante na sua produção teórica, e que será discutida aqui. Pela primeira vez, ele admite, de maneira clara e direta, que a configuração artística de uma temporalidade social marcada por certa "calamidade homogênea, difusa" - os termos são do crítico - poderia tornar "mais inteligível e articulada" a sua matéria histórica. ${ }^{279}$ Essa perspectiva, cheia de consequências teóricas e políticas na trajetória do autor, formula-se no ensaio sobre Os fuzis (1964), de Ruy Guerra, em que o crítico tenta definir a "dialética inócua" do filme à luz da sua possível função política imediata. O seu anseio de intervenção, entretanto, teria que buscar ancoragem noutro chão histórico-social, calcinado por 1964, que dissociava pela força bruta o contato entre os pobres e os estratos médios intelectualizados. De fato, em "O cinema e Os fuzis" (1966), conceitos e categorias de análise adotados até então por Schwarz lhe parecem, até certa medida, politicamente limitados (segundo os parâmetros do autor na época). Essa dimensão de impasse se instaura logo no famoso incipit do texto, no qual o crítico se dispõe a aferir a eventual coerência simbólica da obra a partir do seu modo específico de inserção no aparelho tecnológico e econômico. Diz Schwarz:

\footnotetext{
${ }^{277}$ Na sua turma de Ciências Sociais, que tinha entre 25 e 30 alunos, a participação política se restringia a "Weffort e mais um ou dois que também eram comunistas", segundo Michael Löwy, um dos amigos mais próximos a Schwarz durante os anos de graduação. Cf. Gomes, Ângela de Castro; Reis, Daniel Aarão. "Um intelectual marxista: entrevista com Michael Löwy". In: Tempo. Rio de Janeiro, 1996, v. 1, n. 2, pp. 166-183. A citação de Schwarz encontra-se em "Um seminário de Marx". In: Sequências brasileiras, op. cit., p. 89.

${ }^{278}$ Entrevista ao autor, op. cit.

${ }^{279}$ Schwarz, "O cinema e Os fuzis". In: Civilização Brasileira. Rio de Janeiro, 1967, n. 9/10, p. 220.
} 


\begin{abstract}
Assim como nos leva à savana, para ver um leão, o cinema pode nos levar ao Nordeste, para ver retirantes. Nos dois casos, a proximidade é produto, construção técnica. A indústria, que dispõe do mundo, dispõe também de sua imagem, traz a savana e a seca à tela de nossos bairros. Porque garante a distância real, entretanto, a proximidade construída é uma prova de força: oferece a intimidade sem o risco, vejo o leão, que não me vê. E quanto mais próximo e convincente o leão estiver, maior o milagre técnico, e maior o poder de nossa civilização. A situação real, portanto, não é de confronto vivo entre homens e fera. O espectador é membro protegido da civilização industrial, e o leão, que é de luz, esteve na mira da câmara como podia estar na mira de um fuzil. No filme de bichos, ou de "selvagens", esta constelação das forças é clara. Doutro modo, ninguém ficaria no cinema. Por este prisma, a despeito de sua estupidez, resulta destas fitas uma noção justa de nosso poder; o destino dos bichos é de nossa responsabilidade. Noutros casos, entretanto, a evidência tende a se apagar. (...) $\mathrm{Na}$ identidade perde-se a relação, desaparece o nexo entre o Nordeste e a poltrona em que estou. Conduzido pela imagem sinto sede, odeio a injustiça, mas evaporou-se o principal; saio do cinema arrasado, mas não saio responsável, vi sofrimento, mas não sou culpado; não saio como beneficiário, que sou, de uma constelação de forças, de um empreendimento de exploração. ${ }^{280}$
\end{abstract}

De fato, lidando com o olhar industrial do cinema, Schwarz busca nesse texto a forma por meio da qual Os fuzis produz ativamente a sua recepção social, tencionando organizá-la em termos coletivos e radicalmente políticos. Essa questão é central ao longo de todo o ensaio. A introdução e o desfecho de "O cinema e Os fuzis" perguntam-se pelo modo como essa obra incide diretamente sobre a realidade mesma (um aspecto que, a rigor, não tem relevância destacada nos artigos anteriores). Esse âmbito de interesses assume nota específica, interna à fatura do filme, a partir da conceituação schwarziana sobre "hiato" vigente na montagem. ${ }^{281}$ Para o crítico, há n'Os fuzis "duas fitas incompatíveis: um documentário da seca e da pobreza, e um filme de enredo". ${ }^{282}$ Num plano determinado, a câmera enquadra em ação um grupo de soldados - atores profissionais - enviados ao sertão do Nordeste para proteger armazéns sob ameaça de saque. São sequências dotadas de curva dramática, profundidade psicológica e, nelas, configuram-se destinos individuais, seguindo aqui a argumentação de Schwarz. Contudo, nos instantes em que a câmera se volta para a massa de retirantes, retrata-se de "fora" a fome e os ritos mágico-religiosos, prevalecendo um registro próximo ao documentário. A gestualidade inerte e a fisionomia opaca dos camponeses projetam a imagem de uma "miséria pré-traçada" -

\footnotetext{
${ }^{280}$ Ibidem, pp. $217-8$.

${ }^{281}$ Ibidem, p. 222.

${ }^{282}$ Ibidem, p. 218.
} 
nos termos de Schwarz -, sem desdobramentos práticos da "História" (de acordo com o sentido que essa referência assume nos seus primeiros textos). ${ }^{283}$

No entanto, dessa vez, a falta de "História" na obra não é entendida, a priori, como "defeito" estético. Para Schwarz, o "nexo importante" d'Os fuzis está mesmo na "ausência de um nexo direto" entre o campo dos militares e o campo dos retirantes, o dito "hiato" que o crítico objetiva interpretar. ${ }^{284}$ Ele demonstra como a mobilidade no espaço social e o entrechoque de consciências individuais aparecem restritas ao enfoque marcadamente ficcional dos soldados, a serviço dos donos de mercadorias, o que redimensiona e qualifica o desenvolvimento dramático como um todo. Nesse enredo descosido, "uns são para ver (os flagelados), e outros para compreender (os soldados)", diz Schwarz. ${ }^{285}$ Em outros termos, ao situar o centro do drama na esfera dos ocupantes, que vieram da cidade, os momentos de crise e os pontos culminantes da narrativa de Ruy Guerra aparecem deslocados do antagonismo principal, que opõe proprietários e camponeses. A alternância na tela desses universos sociais dissociados produz o que Schwarz chama de "dialética inócua", confinada ao âmbito moral dos agentes da repressão, e, desse modo, desprovida do instante de "desmascaramento radical". ${ }^{286}$ Essa temporalidade social, diz ele, não transmite "consciência" e nem organiza sujeito histórico, que é apenas pressentido, "remotamente ameaçador". ${ }^{287}$ No entanto, ainda segundo o autor, é justamente na passagem por essa dimensão de "nãoHistória" - o modo pelo qual o filme registra a miséria - que Os fuzis acede à sua materialidade social, incorporando uma descontinuidade prática como o seu princípio compositivo mais fundamental.

Pela primeira vez, Schwarz escreve sobre uma forma estética brasileira que parece não se fundar, de alguma maneira, no rompimento da esfera pessoal do outro. Nas análises anteriores, viu-se como o crítico sustenta uma aversão notável aos mecanismos artísticos ou para-artísticos de envisgamento do leitor nos romances brasileiros, que, para ele, reproduzem e acirram uma indistinção perversa entre autor,

\footnotetext{
${ }^{283}$ Ibidem, p. 218.

${ }^{284}$ Ibidem, p. 222.

${ }^{285}$ Ibidem, p. 218.

${ }^{286}$ Ibidem, p. 221.

${ }^{287}$ Ibidem, p. 219.
} 
obra e público. Já na representação do Nordeste feita n'Os fuzis, o pânico social da alteridade, e os dispositivos de coação que o sustenta, são tematizados e distanciados pela forma do filme, que limita as identificações agônicas com a barbárie fixada pela câmera, segundo Schwarz. No retrato do campo popular, ele ressalta a recusa de fixar um "contínuo psicológico onde não há contínuo real". ${ }^{288} \mathrm{E}$ isso teria ocorrido, entre outros aspectos, por meio do uso de um close-up "abstruso", ${ }^{289}$ que repõe sempre algo de recôndito nas expressões da miséria, negando-se a ver ali mais que "anacronismo e inadequação". ${ }^{290}$ Esse registro é valorizado pois mostraria que "aquém da transformação não há diferença que importe". ${ }^{291}$ De qualquer modo, subtraindo-se o corrimão autoindulgente da compaixão pelos desvalidos, o filme - nas palavras do crítico - "força a identificação antipática" entre os consumidores de cinema e as autoridades policiais na tela, rompendo-se a postura contemplativa. ${ }^{292} \mathrm{E}$ o espectador d'Os fuzis seria exposto à sua "responsabilidade moral" pela injustiça projetada na tela; apontando-se, na mesma medida, a insuficiência política desse tipo de vínculo. ${ }^{293}$

No final do ensaio, Schwarz afirma que, "no filme de miséria, pressentimos a conflagração", delineando-se uma situação social "altamente inflamável". ${ }^{294}$ Contudo, nessa dialética intrincada d'Os fuzis, fundada na ausência de um "nexo direto" entre as classes - seguindo a sua explicação -, onde localizar certa necessidade inelutável de uma matéria social que, ao realizar as contradições internas, produz em si o processo de reversão no seu contrário? Schwarz diz que, por ora, apenas um dos polos (o dos mandantes) está "à altura da História". ${ }^{295} \mathrm{E}$, de fato, a superação futura de uma condição de miséria que "fermenta, mas não explode", ${ }^{296}$ não toma - nesse texto em específico - a feição lógica e tangível de uma racionalização gradual da sua matéria histórica. Na solução dada pelo crítico, postula-se: “O que a câmara mostra nas faces

\footnotetext{
${ }^{288}$ Ibidem, p. 217.

${ }^{289}$ Ibidem, p. 222.

${ }^{290}$ Ibidem, p. 219.

${ }^{291}$ Ibidem, p. 219.

${ }^{292}$ Ibidem, p. 220.

${ }^{293}$ Ibidem, p. 222.

${ }^{294}$ Ibidem, p. 222.

${ }^{295}$ Ibidem, p. 219.

${ }^{296}$ Ibidem, p. 219.
} 
abstrusas, ou melhor, o que as torna abstrusas, é a ausência da explosão, o salto que não foi dado". ${ }^{297}$ Seja como for, a possível unidade e a coerência construtiva dessa obra, enquanto requisitos precípuos para a consecução da sua imanência estética, só poderiam constituir-se numa virada in extremis, de todo modo disruptiva, que negaria a dita "dialética inócua", e cuja ultrapassagem se daria mediante o seu próprio fazerse prático no real.

No exame d'Os fuzis, e visando sustentar - em termos lógicos e estéticos - a possibilidade mesma de coexistência entre duas formas de temporalidade que não se integram uma na outra, Schwarz recorre a uma conceituação de Althusser, elaborada a partir de outros fundamentos sociais. Analisando cenas da peça El Nost Milan, de Carlo Bertolazzi, o filósofo francês havia descrito ali a presença simultânea de um "tempo parado onde ainda nada se passa que se assemelhe à História" (associado por ele à impotência social do "subproletariado" milanês no final do século 19) e uma temporalidade plena e "breve como um relâmpago", restrita à esfera de alguns conflitos pessoais, e na qual se vê o "esboço" de um drama. ${ }^{298}$ Os comentários althusserianos sobre esse desenvolvimento dramático "assimétrico e descentrado", marcado por uma "alteridade sem resolução", miravam as formas de "consciência" que supõem "sair de si pela sua própria dialética interna", ${ }^{299}$ tendo como ponto de fuga o teatro de Brecht. Já no ensaio de Schwarz o argumento sofre uma torção histórica objetiva, servindo - ainda que de modo indireto - como sanção à ruptura armada sem prévia implantação social. É o crítico quem formula, a partir da forma d'Os fuzis, as possíveis consequências políticas dessa vigência simultânea de dois tempos sociais que não se misturam: "Onde nos identificamos, desprezamos; de modo que a compaixão passa, necessariamente, pela destruição de nossos emissários (os soldados e agentes da repressão), e, neles, de uma ordem das coisas". 300

\footnotetext{
${ }^{297}$ Ibidem, p. 219.

${ }^{298}$ Essa peça havia sido encenada em Paris pelo Piccolo Teatro de Milão, em julho de 1962. Na análise de Althusser, o descompasso entre a figuração do tempo dialético, "maduro" e irreversível, e outro "não-dialético" no qual a contradição interna não produz o seu devir -, tende a ser generalizado como algo constitutivo e "essencial em toda tentativa teatral de caráter materialista". Ver "O Piccolo, Bertolazzi e Brecht" (Notas sobre um teatro materialista)". In: Análise crítica da teoria marxista. Rio de Janeiro: Zahar, 1967, pp. 114-33.

${ }^{299}$ Ibidem, pp. 125-6.

300 "O cinema e Os fuzis", op. cit., p. 220.
} 
De qualquer modo, em "O cinema e Os fuzis”, a identificação da lógica interna do filme não se basta e nem se confunde com os limites da obra mesma. O ensaio de Schwarz visa demonstrar como o trabalho de Ruy Guerra inclui e ultrapassa o âmbito da obra individuada consistente em si, incidindo diretamente sobre as formas de produção da vida social, em cuja possibilidade de transformação o filme - e o crítico arriscam o seu parâmetro último. ${ }^{301} \mathrm{E}$ esse momento de volição d'Os fuzis não se configura como mero efeito externo à sua compleição formal. $\mathrm{Na}$ análise do crítico, o "hiato" social brasileiro internalizado pela montagem configura-se como uma instância da obra, pois nele se destaca o valor de uso para uma práxis radical que virá (e essa espera orienta o exercício da sua "autonomia" artística). A transitividade explosiva d'Os fuzis - e do ensaio de Schwarz - imagina, a partir da atualidade brasileira, decisões do produtor e do receptor baseadas em demarcações nítidas de interesses no campo da luta de classes, que apresenta aqui virtualidades emancipatórias. De qualquer modo, é essa tentativa de demarcação de uma "linha de classe quando está em questão o corte cultural" que exaspera Gérard Lebrun, ${ }^{302}$ para quem essa análise de Schwarz gera “confusão" entre o critério estético e o político, pois "o Belo, aqui, só agrada em função do conceito". 303

Em 1966, quando são escritas essas linhas sobre Os fuzis, Schwarz participa de reuniões clandestinas que buscavam, àquela altura, construir estratégias de luta coletiva contra a política de arrocho salarial - implementada logo no início da ditadura - e iniciar uma possível restruturação das organizações de classe, que tinham sido destroçadas pelo arrastão de 1964. Os principais sindicatos do país, dissociados das

\footnotetext{
${ }^{301}$ Sobre a dimensão estética e política desses modos de "trabalho em processo", e considerando o modelo brechtiano - que mobiliza aqui a imaginação de Schwarz num sentido diverso da noção de "forma" vista nos seus ensaios anteriores -, as melhores referências são: Benjamin, Walter. "O autor como produtor" In: Magia e técnica, arte e política. São Paulo: Brasiliense, 1994, pp. 120-136; do mesmo autor, "Bert Brecht". In: Documentos de cultura, documentos de barbárie: escritos escolhidos. São Paulo: Cultrix/Editora da Universidade de São Paulo, 1986, pp. 121-5; e Pasta, José Antonio. Trabalho de Brecht. São Paulo: Duas Cidades; Ed. 34, 2010.

${ }^{302}$ Cf. Lebrun, Gérard. "Algumas confusões, num severo ataque à intelectualidade”. In: Discurso (USP), n. 12, 1980, p. 149 (grifo do autor).

${ }^{303}$ A esse respeito, vale lembrar que o "Belo" em questão encontra-se impregnado, desde os modos de produção da sua linguagem, por uma convergência experimental entre a imaginação artística e a enquete sociológica, por meio da qual o diretor moçambicano procurou construir um conhecimento articulado sobre a sua matéria histórica. Ruy Guerra se refere a Os fuzis como o "resultado de uma pesquisa quase obsessiva, de um estudo muito minucioso e atento" sobre o "subdesenvolvimento" brasileiro. Nas suas palavras, essa situação era "familiar ao meu mundo, mas apercebi-me logo que aquele subdesenvolvimento tinha especificidades que eu tinha de conhecer e interiorizar. Falei com todo tipo de pessoas, li tudo o que consegui pegar. Fiz um enorme esforço para entrar e interpretar aquela realidade". Cf. Chaves, Rita; Cabaço, José Luís. "Ruy Guerra: cidadão de várias pátrias, passageiro de diferentes revoluções" (entrevista). In: Via Atlântica. São Paulo, n. 21, jul. 2012, p. 138. E Lebrun, "Algumas confusões, num severo ataque à intelectualidade", op. cit., p. 147.
} 
lideranças políticas que emergiam no pré-golpe, estavam prostrados pela repressão e pela intervenção do Estado policial. Nesse contexto de derrota histórica e ressentimento social acumulado, alguns ex-militares de baixa patente - perseguidos e expurgados das Forças Armadas entre 1961 e 1964 - também começam a gravitar do brizolismo para organizações declaradamente marxistas, que ainda não haviam decidido pela via armada. ${ }^{304}$ Num desses encontros, um grupo de operários solicita a Schwarz uma explicação didática da ideia marxista de mais-valia, visando utilizar esse material em seminários de formação. O texto originário dessa encomenda política, que resultaria em "Didatismo e literatura" (1968), vem a público - refundido e ampliado - apenas dois anos mais tarde (na última edição de Teoria e Prática), quando a tática armada assumia a dianteira nos coletivos de oposição. ${ }^{305}$

Nesse momento em que Schwarz busca conexões políticas - pontuais e limitadas - fora da sua classe de origem, ele começa a ter suas atividades monitoradas pelos órgãos de informação e de repressão do Exército. O seu prontuário no Departamento Estadual de Ordem Política e Social de São Paulo (Deops-SP) data de 20 de setembro de 1966. Nesse dia, Schwarz é detido em frente ao Teatro de Arena, quando recolhia - ao lado de um grupo de militantes - apoios para um abaixo-assinado contra a prisão anterior de um colega. Eles são surpreendidos por uma blitz policial pouco antes do início da sessão noturna do Arena: "Pegaram todo mundo, encostaram na parede, e depois puseram dentro de um ônibus. Fomos para o DOPS". ${ }^{306}$ Era a primeira vez que a repressão alcançava diretamente o crítico. Submetido a interrogatório, ele vira a noite numa cela coletiva, e permanece sob custódia policial até a tarde do dia seguinte. O episódio teria ainda desdobramentos futuros, que indicam como, nesse momento, não havia clareza sobre as possibilidades do aparelho repressivo. Em 1967, o mesmo endereço de residência informado pelo autor aos militares - por ocasião da sua prisão temporária - seria divulgado como sede de redação da Teoria e Prática, que tinha Schwarz como um dos editores, e já estava vinculada aos primeiros preparativos para o enfrentamento armado contra a ditadura.

\footnotetext{
${ }^{304}$ Gorender, Jacob. Combate nas trevas. São Paulo: Ática, 1987, p. 131.

305 "Didatismo e literatura" (1968) é discutido adiante. Para o relato de Schwarz, ver "Na periferia do capitalismo" (entrevista a Mariluce Moura e Luiz Henrique Lopes dos Santos). In: Martinha versus Lucrécia, op. cit., p. 304.

${ }^{306}$ Essa passagem de Schwarz pelos órgãos de repressão está registrada no Fundo Secretaria da Segurança Pública - Acervo Deops-SP (Departamento Estadual de Ordem Política e Social de São Paulo), sob o Prontuário ${ }^{\circ}$ 143.503, disponível para consulta no Arquivo Público do Estado de São Paulo. Entrevista ao autor, op. cit.
} 


\section{Entre mercadorias e símbolos da revolução}

A partir de "O cinema e Os fuzis" (1966), ganham espaço nos textos de Schwarz as formas e os gêneros interventores, híbridos, com vocação publicística acentuada, por meio dos quais o seu ensaio também busca bases sócio-políticas de difusão. Além do cinema, os seus objetos de interesse incluiriam - até o final dos anos 1960 - o editorialismo político de jornal, o problema do didatismo em artes, o teatro político pós-1964, a canção tropicalista, os impasses da arquitetura brasileira, entre outros assuntos. O regime unificado e autorreferido da "obra" artística, a partir do qual o crítico vinha sublinhando a não realização do realismo sério e problematizante na literatura brasileira, desloca-se e perde - de modo temporário - o estatuto de ideia reguladora dominante. Entre 1967 e 1968, o momento é de coexistência contraditória entre as primeiras ações de "propaganda armada" da revolução e os inícios de um mercado de bens culturais em larga escala no Brasil, sob estado de exceção. ${ }^{307}$ Nesse contexto, a crítica de Schwarz se perfaz mais tangível pelas apostas políticas do autor, deixando-se expor frontalmente à vulnerabilidade histórica dos seus materiais. Ele imagina ser possível, então, apropriar-se ativamente dessa maior fungibilidade dos objetos e categorias de análise, de modo a transformá-los numa força produtiva no presente, impulso que esbarra em vários limites objetivos. Ainda assim, a procura de pontos de incidência estratégicos para sustentar esse desejo de intervenção leva o autor, como se vê, a reformular e às vezes ampliar procedimentos críticos rotinizados anteriormente, estruturando-se novos impasses teóricos e políticos.

É o que se apresenta, por exemplo, em "Nota sobre vanguarda e conformismo" (1967), ensaio publicado no segundo número da Teoria e Prática. ${ }^{308}$ Nesse trabalho, o material de análise do crítico são depoimentos de regentes e compositores brasileiros ditos de "vanguarda", que seriam próximos ao tropicalismo (movimento que despontava naquele ano). As obras desses músicos, porém, não interpõem limite epistemológico para a delimitação do problema que interessa a Schwarz. Não está em pauta nenhuma circunscrição a priori do "estético". A esse respeito, não falta também o viés de provocação do crítico: “Como a linha das respostas me pareceu uma só, não

\footnotetext{
${ }^{307}$ A partir de outra perspectiva de análise, Renato Ortiz demonstra como a "indústria cultural" propriamente dita se constitui no Brasil durante os anos 1960 e 1970, sob a ditadura empresarial-militar. Cf. A moderna tradição brasileira - cultura brasileira e indústria cultural. São Paulo: Brasiliense, 1988.

308 “Nota sobre vanguarda e conformismo". In: Teoria e Prática. São Paulo, 1968, n. 2, pp. 127-32.
} 
distingui entre os quatro (músicos)". ${ }^{309}$ De fato, o seu objeto é um complexo econômico, cultural e político, que, no Brasil pós-golpe, estaria conjugando "progresso técnico e conteúdo social reacionário", o que tornava "ambígua a noção de progresso", segundo Schwarz. ${ }^{310}$ Os termos específicos dessa sua crítica ao "progresso" serão discutidos logo adiante. Por ora, vale destacar que o autor parte aqui da verificação atual de que a cultura dita desinteressada descia ao comércio dos interesses comuns, mas desvinculando-se de uma ação política direta. Nessa falsa superação da distância entre arte autônoma e vida social, diz ele, é como se a própria "linguagem cotidiana" agora "espontaneamente aspirasse à publicidade, à forma da mercadoria", que já tendia a "governar" desde o "momento da produção" artística. ${ }^{311}$ Embora ele reconheça que essa identidade de origem entre produção de mercadorias e vida cultural no Brasil - sem anteparo ou mecanismo de atenuação ao nexo mercantil -, tinha o "ar de coisa vista e inédita a um tempo", ${ }^{312}$ o ensaio privilegia o combate direto à ideologia do estético vigente na época. E o autor visa demonstrar, sobretudo, que a suposta abolição da distância entre a alta cultura e o popular, anunciada como uma unificação dos processos dicotômicos de produção e consumo, oblitera a injunção contraditória do capital, servindo à justificação de antagonismos reais.

Ao mesmo tempo, Schwarz realiza nesse ensaio uma aposta política no que ele chama de "impasse" entre a "potência social crescente da comunicação" de massa decorrente de um "esforço industrial e portanto coletivo", diz ele - e o "uso privado e idiossincrático, 'artístico', que faz dela a arte burguesa". ${ }^{313}$ Nesse texto, o crítico fala diretamente em crise do elemento artístico, que é referido como um terreno "minado". ${ }^{314}$ Isso porque o "artístico" em questão estaria sob pressões violentas e contraditórias, "seja porque sustenta posições e linguagem do individualismo burguês, desmentidas no interior do próprio capitalismo, pela socialização parcial da produção,

\footnotetext{
${ }^{309}$ São eles: Rogério Duprat, Damiano Cozzela, Willy Correa de Oliveira e Gilberto Mendes, que haviam sido entrevistados por Júlio Medaglia. Ver "Música não-música antimúsica”. In: Suplemento Literário d'O Estado de S. Paulo, 22 abr. 1967, p. 33. "Nota sobre vanguarda e conformismo", op. cit., p. 127.

${ }^{310}$ Ibidem, p. 127.

${ }^{311}$ Ibidem, p. 129.

${ }^{312}$ Ibidem, p. 130.

${ }^{313}$ Ibidem, p. 128.

${ }^{314}$ Ibidem, pp. 129-30.
} 
seja porque não vende". ${ }^{315}$ De qualquer modo, a "natureza coletiva dos mass media", entendida pelo crítico como resultado de uma progressiva racionalização das forças produtivas, encontra-se em tensão com o nexo social "particularista" vigente sob o capitalismo, segundo ele. ${ }^{316}$ Para o jovem Schwarz, esse mesmo processo histórico que fulminava a unicidade da "obra" poética, convulsionando os seus limites tradicionais, poderia escapar à mera reprodução da lógica do consumo. Ele tem a expectativa de uma ultrapassagem do "artístico" - enquanto esfera antes separada das demais formas de produção social - ao território antitético do político, de modo a restituir uma nova totalidade para essa produção simbólica "minada", e que poderia, então, projetar-se num trabalho organizativo sobre o real. ${ }^{317}$

Quando Schwarz formula essa hipótese, iniciava-se a entrada massiva do mercado e da mídia no campo da cultura no Brasil - como dito anteriormente -, o que ocorria sob amplo apoio do Estado, em particular por meio da racionalização empresarial de um sistema abrangente de telecomunicações. E os avanços técnicos associados a esse moderno mercado de bens simbólicos pareciam em disputa. De fato, nas organizações políticas de oposição, era dominante a tese sobre a suposta estagnação estrutural do capitalismo brasileiro. ${ }^{318}$ De acordo com essa perspectiva, a política econômica antipopular da ditadura, a sua composição retrógada de forças políticas e a articulação subordinada ao imperialismo estavam obstruindo o desenvolvimento efetivo das forças produtivas no país (em ato contínuo, anunciavamse as famigeradas “condições objetivas" para a revolução). Atento à confluência entre modernização técnica e pressupostos sociais regressivos, Schwarz não incorpora aqui a tese estagnacionista. Ao mesmo tempo, as suas avaliações sobre as "ambiguidades" do "progresso" brasileiro e a imaginada dialética histórica do "artístico" ao "político" estão permeadas, como se viu, pelo anseio de reatar certa convergência estrutural

\footnotetext{
${ }^{315}$ Ibidem, p. 130.

${ }^{316}$ Ibidem, p. 130.

${ }^{317}$ A referência teórica adotada aqui, explicitada por Schwarz, é Benjamin, Walter. "A obra de arte na era de sua reprodutibilidade técnica”. In: Magia e técnica, arte e política. São Paulo: Brasiliense, 1994, pp. 165-96.

${ }^{318}$ Ainda em 1967, ano da escrita deste ensaio de Schwarz, Celso Furtado previa uma "pastorização" do Brasil sob a ditadura. Segundo ele, os militares sacrificariam o desenvolvimento nacional em prol da "estabilidade". E, ante a "paralisação dos investimentos industriais", os trabalhadores subempregados nas cidades seriam impelidos a se deslocar para o campo, num processo de revalorização do setor primário. Cf. Furtado, Celso. "Brasil: da República Oligárquica ao Estado Militar”. In: Brasil: Tempos Modernos. São Paulo: Paz e Terra, 1968, p. 16. Para a tese "estagnacionista" sobre a economia brasileira, ver também, do mesmo autor, Subdesenvolvimento e estagnação na América Latina. Rio de Janeiro: Civilização Brasileira, 1966.
} 
entre o viés contestatário da arte moderna - pensada como secessão dessublimadora da instituição "artística", em litígio negativo com a integração capitalista - e os possíveis caminhos para a revolução social no Brasil. Nesse sentido, o raciocínio do crítico opera a partir da visão de um conflito, ${ }^{319}$ e não de uma simbiose, entre o desenvolvimento das forças produtivas materiais e o regime de apropriação privada do produto social; o que, por vias próprias, também o aproxima da guerrilha como alternativa histórica plausível.

De qualquer modo, esse regime de historicidade bifronte e contraditório que caracteriza o ensaio de Schwarz é dissociado, de modo unilateral, na leitura feita pelo historiador Carlos Guilherme Mota. Na sua história das ideologias no Brasil, Mota se serve de "Nota sobre vanguarda e conformismo" para indicar o momento em que, segundo ele, supera-se aqui o "ideal mannheimeiano de intelectual", que teria tido plena vigência no país desde os anos $1930 .{ }^{320}$ Por meio dessa referência, ele supõe a negação local de uma intelligentsia que plana "acima e à frente do processo histórico", desvinculada de amarras com as classes efetivamente constituídas (que, na teoria de Mannheim, têm alvos definidos e travam disputa aberta). Desse modo, além de contornar um problema sociológico clássico, o mérito do texto de Schwarz - segundo ele - teria sido dispensar as noções de "linearidade, etapa, processo", que "ficavam estouradas por dentro" após a supressão do "populismo". ${ }^{321}$ Para Mota, isso se manifesta numa suposta defesa schwarziana da "concepção artesanal da cultura". 322

Para Schwarz, entretanto, a mudança de função das formas artísticas e dos meios de produção intelectual no Brasil era um fato objetivo, que redefinia as noções de "amador" e de "profissional". Ou seja, a perda - imediatamente desfrutável - do isolamento relativo da atividade artística estava na "ponta de desenvolvimentos

\footnotetext{
${ }^{319}$ Ibidem, p. 130.

${ }^{320}$ Cf. Mota, Carlos Guilherme. "Vanguarda e conformismo, segundo Roberto Schwarz". In: Ideologia da cultura brasileira (1933-1974). São Paulo: Ed. 34, 2014, p. 288.

${ }^{321}$ Esse texto de Schwarz não se encaixa em nenhum dos polos ideológicos postulados por Carlos Guilherme Mota para descrever a cultura brasileira no imediato pós-golpe. De um lado, segundo ele, haveria certo reforço de "esquemas simples e lineares para torná-lo (o processo histórico) pretensamente utilizável", o que o autor associa à "orientação rígida de um marxismo cristalizado". Já o seu oposto simétrico, mais "inovador", seria marcado por "noções de ruptura e de descontinuidade dos processos históricos-ideológicos", que seriam penetradas também por "teorias impossibilistas relativizadoras". Ibidem, pp. 288-9.

${ }^{322}$ Ibidem, p. 285.
} 
históricos reais". ${ }^{323}$ E era necessário lidar ativamente, de modo crítico, com esse estágio de neutralização mercantil do "artístico", que poderia exprimir - a depender da luta política - um momento dialético, passível de ser ultrapassado em direção a formas emancipadas de produção social. Nos termos do crítico, "se a crise do sujeito artístico reflete a crise da propriedade privada e a presença virtual do socialismo, capitalismo $e$ indústria não são idênticos e inseparáveis, como não são idênticas a produção artística e a de mercadorias". ${ }^{324}$ O foco encontra-se, portanto, na tentativa de superação do capitalismo, e não num retorno ao artesão cultural.

Contudo, os limites desse ensaio de Schwarz semiautorizam, por assim dizer, as vinculações abstratas de Carlos Guilherme Mota. A crítica schwarziana permanece, aqui, um passo aquém do problema que ela delimita para si, na medida em que o texto não formula hipóteses sobre o fundamento histórico dessa disponibilidade no mercado que alcançava a intelectualidade e os artistas de esquerda, após o contravapor de 1964. De fato, o ponto de fuga de "Nota sobre vanguarda e conformismo" deságua em considerações gerais sobre a "posição intermediária" do "intelectual burguês de esquerda", que, habitando uma "zona furta-cor", transige entre "veneração e desprezo pelo consumo". ${ }^{325}$ Sob o início da mercantilização das lutas políticas do pré-1964, o crítico assinala - sem complacência - que o ímpeto combativo e o experimentalismo artístico, abastecidos no ciclo anterior, estavam girando em falso no país. "O cinismo apologético não é fácil de distinguir da crítica materialista”, dizia ele, ${ }^{326}$ após o exame das cumplicidades comerciais da "vanguarda" cultural. Contudo, na ausência das bases materiais dessa derrapagem histórica, e sob a experiência ainda recente de uma mobilização política de trabalhadores que havia causado fissuras na cultura burguesa pré-golpe, Schwarz vai alimentando "impulsos políticos" - a expressão é dele relacionados à possível reorientação prática, radicalmente coletiva, de uma cultura convertida ao "mercado anônimo". 327

\footnotetext{
323 "Nota sobre vanguarda e conformismo", op. cit., p. 130.

${ }^{324}$ Ibidem, p. 130 (grifo do autor).

${ }^{325}$ Ibidem, pp. 131-2.

${ }^{326}$ Ibidem, p. 132.

${ }^{327}$ Ibidem, p. 129.
} 
Esses experimentos críticos de Schwarz, que não alcançam uma articulação sistemática da sua matéria histórica - e estão, sobretudo, à procura de um equivalente prático-político -, culminam em "Didatismo e literatura" (1968), o último texto publicado pelo autor antes do exílio. Esse trabalho, conforme citado anteriormente, já é resultado de uma demanda colhida diretamente na luta clandestina (quando, ainda em 1966, um grupo de trabalhadores pede ao crítico uma síntese do conceito de maisvalia). Assim, ao mesmo tempo em que responde às exigências da agitação política, a versão ampliada desse escrito se propõe a expor a "força transformadora" do gênero didático, no qual - segundo Schwarz - a "estética é puramente política, e chega sem querer onde a literatura, ou parte dela, há muito quer chegar". ${ }^{328} \mathrm{O}$ título original do artigo vinha precedido pela expressão "um folheto de iniciação política", destacandose essa destinação prática, algo que seria suprimido na edição em livro (em 1978). ${ }^{329}$ De qualquer modo, nesse momento, Schwarz imagina ser possível conceber esse texto em sua dimensão prático-demonstrativa, por assim dizer, de modo que a reflexão sobre a prosa didático-política e a intervenção prática de classe pudessem se converter reciprocamente uma à outra. Nesse sentido, conceitos como o de "obra", enquanto instância divorciada da sua fruição individual, bem como a noção de sujeito "singular", seriam o tempo todo relativizados por essa projeção incisiva na imediatidade, em busca dos possíveis vínculos para uma transformação radical da realidade brasileira. Esse ensaio, se ainda é possível dizê-lo, assume mesmo um caráter modelar, apresentando-se como uma espécie de protótipo que se pretende imitável e utilizável na "luta de classes no interior da linguagem e das representações autorizadas", segundo o autor. ${ }^{330}$

Na construção da figura literária de Bertha Dunkel, Schwarz define ainda os contornos de uma prosa de intervenção ideal no seu tempo presente. E ele faz aqui o elogio de uma linguagem anônima, partidária, que deveria restituir o "esplendor da nitidez" aos seus objetos, com "rigor de filigrana" - afim à isenção clarificadora dos pormenores realistas - e viés de "epitáfio", ${ }^{331}$ próprio à configuração anti-ilusionista

\footnotetext{
328 "Um folheto de iniciação política - Didatismo e literatura". In: Teoria e Prática. São Paulo, 1968, n. 3, p. 151.

${ }^{329}$ Na Teoria e Prática, o título original era "Um folheto de iniciação política - Didatismo e Literatura”. Na edição d'O pai de família (1978), o texto aparece relacionado no sumário apenas como "Didatismo e literatura", variandose ainda - na página de abertura do ensaio - para "Didatismo e literatura (Um folheto de Bertha Dunkel)".

330 “Um folheto de iniciação política - Didatismo e literatura”, op. cit., p. 151.

${ }^{331}$ Ibidem, p. 148.
} 
de uma ordem social em via de ser ultrapassada. Como se sabe, essa sintaxe franca e direta dos interesses de classe, dotada de um estilo verbal "entre ascético e assassino" - declaradamente inspirada em Brecht -, não tinha "equivalente no imaginário brasileiro" (como reconheceria Schwarz), ${ }^{332}$ marcado pela atualização de relações de dependência e sujeição pessoal direta, e também pelos atalhos sombrios da malandragem. ${ }^{333}$ E que derivam, dito de modo breve, de bases materiais instáveis para a afirmação da autonomia do outro, próprias ao país periférico de herança escravista. Desse modo, por exemplo, a promiscuidade crítica entre o assunto baixo e o gênero alto, buscada aqui pelo crítico, assumia um sentido histórico diferente. ${ }^{334}$ No entanto, se é verdade que Schwarz pede ao seu material o que ele não pode lhe dar - num momento histórico que pendia para o inconformismo internacionalista -, essa linguagem que anseia a certo anonimato subversivo imagina-se justificada nos termos da situação local. Em abril de 1968, quando é publicado "Didatismo e literatura", o autor aposta que o militante ilegal e clandestino, que começava a realizar a travessia para a luta armada, constituiria um primeiro eixo estratégico em torno do qual poderia se desdobrar a resistência contra a ditadura. Esse o pano de fundo brasileiro daquela vibração histórica inaugural vigente no texto, que, por meio de referências diretas à Alemanha de Weimar, orienta-se pela quebra da irracionalidade obsoleta da ordem burguesa, que estaria perdendo a dianteira histórica. ${ }^{335}$

Na medida em que esses signos vinculados à "iminência da Revolução" não encontram enraizamento prático e atual, é a própria instância da autoria anônima instaurada por Schwarz - que se desdobra como figura análoga e antecipatória dessa

\footnotetext{
${ }^{332}$ Esse argumento é desenvolvido por Schwarz. Diz ele: "A inteligência de vida que está sedimentada em nossa fala popular tem sentido crítico específico, diferente da gíria proletária berlinense, educada e afiada pelo enfrentamento de classe. Conforme um descompasso análogo entre as respectivas ordens do dia, o nosso zéninguém precisava ainda se transformar em cidadão respeitável, com nome próprio; ao passo que para Brecht a superação do mundo capitalista, assim como a disciplina da guerra de classes, dependiam da lógica do coletivo e da crítica à mitologia burguesa do indivíduo avulso". Ver "Altos e baixos da atualidade de Brecht”. In: Sequências brasileiras, op. cit., pp. 120-1.

${ }^{333}$ Ver Otsuka, Edu Teruki. Era no tempo do rei: atualidade das Memórias de um sargento de milícias. Cotia, SP: Ateliê Editorial, 2016.

${ }^{334}$ Aspecto que seria reconhecido e desdobrado pelo crítico, sob a forma apropriada de uma "chanchada" política, em A lata de lixo da história (1969). São Paulo: Companhia das Letras, 2014.

335 “Os anos 20, na Alemanha, deram frutos de um radicalismo admirável, ligado à iminência da Revolução. Casais não casavam, pois antes dela não valia a pena, e depois não seria mais necessário; não tinham filhos, pois seria melhor nascer já na era socialista, na era da razão. Entre um passaporte de dois anos, e um de cinco, o de cinco parecia um despropósito, pois logo se aboliriam as fronteiras. Tudo seria revolucionado e racionalizado: coisas, costumes, formas e o modo de produção". "Um folheto de iniciação política - Didatismo e literatura", $o p$. cit., p. 147.
} 
viravolta anunciada, na qual a ruptura e as interversões das barreiras de classe e de profissão impulsionariam a luta política num sentido radical, segundo as expectativas do crítico. No caso Bertha Dunkel, Schwarz é autor de cartilha sobre a mais-valia (sob a desconfiança de promover a "vulgarização" do pensamento), crítico uspiano rigoroso desse panfleto político, tradutor da "versão original" em alemão - que substitui as "batatas alemãs (dos exemplos) pelo feijão nacional, e o arado pela enxada" - e militante revolucionário. ${ }^{336}$ Enquanto recurso utilizado para se proteger da repressão policial, o pseudônimo descentrado glosa ainda os postulados do estruturalismo linguístico. Diferentemente do estatuto discursivo que orientava, então, as "transgressões" dos simpatizantes da intertextualidade, ${ }^{337}$ o seu dispositivo narrativo quer reter os vínculos experimentais entre o trabalho de formalização literária e as demandas de utilidade social. Assim, e acirrando-se ao máximo a premissa de que a "orientação prática dava (e dá) valor poético à razão", 338 Schwarz vê "beleza" desde uma obra teórica como História e consciência de classe - com seu "élan transformador" -, ${ }^{339}$ até os manuais militares de Mao Tsé-Tung, nos quais o crítico diz encontrar o "efeito poético de escritos duros e terra-a-terra". ${ }^{340} \mathrm{Na}$ sua formulação, “a melhor prosa, se é inacessível ao operário, não é a melhor prosa, pois é inevitável que tenha, mesmo que não queira e combata ideologicamente, o prestígio

\footnotetext{
${ }^{336}$ Esse aspecto é discutido por Lidiane Soares Rodrigues. A partir de outra perspectiva, a autora tenta localizar em "Didatismo e literatura" o que ela chama de "utopia" da crítica schwarziana, a sua "peculiar formulação de sociedade alternativa à vigente". Cf. A produção social do marxismo universitário em São Paulo: mestres, discípulos e 'um seminário' (1958-1978). 565 f. Tese (Doutorado em História Social) - USP, 2011, pp. 494-506.

${ }^{337}$ Sem ignorar o fato de que essas teses já se apresentam hoje como velharias ideológicas, porém considerando o seu caráter anterior de arrastão teórico, vale transcrever uma das súmulas sobre o que era entendido, então, como o "estatuto linguístico" da literatura. O francês Roland Barthes, respondendo em 1963 a um questionário da revista Tel Quel, anunciava: "Cada vez que se valoriza ou se sacraliza o 'real' (...), percebe-se que a literatura não é mais do que linguagem, e ainda mais: linguagem segunda, sentido parasita, de modo que ela pode conotar o real, não denotá-lo: o logos aparece então irremediavelmente cortado da praxis; impotente para realizar a linguagem, isto é, ultrapassá-la em direção a uma transformação do real; privada de toda transitividade, condenada a se significar incessantemente ela própria no momento em que ela gostaria de significar apenas o mundo, a literatura é então um objeto imóvel, separado do mundo que se faz". Ainda segundo Barthes, o "objeto da crítica (...) não é o 'mundo', é um discurso, o discurso de um outro: a crítica é discurso sobre um discurso; é uma linguagem segunda ou metalinguagem (como diriam os lógicos), que se exerce sobre uma linguagem primeira (ou linguagem-objeto). (...) Pois, se a crítica é apenas uma metalinguagem, isto quer dizer que sua tarefa não é absolutamente descobrir 'verdades' mas somente 'validades'. (...) As regras a que está sujeita a linguagem literária não concernem a conformidade dessa linguagem com o real, (...) mas somente sua submissão ao sistema de signos que o autor fixou para si mesmo". Cf. Barthes, Roland. "O que é a Crítica”. In: Crítica e verdade. São Paulo: Perspectiva, 2009, pp. 160-1. Da mesma edição, ver ainda "Literatura e Significação", op. cit., p. 172 (grifos do autor).

338 "Um folheto de iniciação política - Didatismo e Literatura”, op. cit., p. 147.

${ }^{339}$ Ibidem, p. 148.

${ }^{340}$ Ibidem, p. 152.
} 
do que é para poucos, o gesto da superioridade social". ${ }^{341}$ Do mesmo modo, a crítica à exploração capitalista, caso não se oriente pelo destinatário numa sociedade de classes, apresenta-se marcada de "impotência prática e falta de especificação". ${ }^{342}$

Na ficção de Bertha Dunkel, Schwarz experimenta uma forma sem função artística primária. $\mathrm{O}$ efeito poético da sua personagem conjuga-se com o trabalho de argumentação didático-política, que o crítico definiu certa vez como a "menos artística das atividades". ${ }^{343}$ Nos termos sugeridos por "Didatismo e literatura", também o problema da precária unidade do ponto de vista narrativo nas obras brasileiras, tópico recorrente desde os seus primeiros ensaios, não se poderia procurar e nem se resolver nos limites da obra em si, que, nesse caso, só deve alcançar a sua eventual coerência interna quando colocada em uso por outros sujeitos históricos em busca de eficácia política. Schwarz relata mesmo que, após a publicação do texto, um “intelectual de renome, que conhecia tudo do movimento operário alemão", declarou "ter lembrança de Bertha". ${ }^{344}$ De modo involuntário, a recepção enviesada da figura literária de Schwarz torna-se um momento constitutivo da sua produção poética, expondo uma vez mais a "vocação" de "elite dirigente acima do social" a que aspira certa classe culta no Brasil, ${ }^{345}$ sob o fardo edificante de moldar a consciência nacional.

De qualquer modo, cabe verificar melhor como essas questões se formulam no texto de Schwarz. Em "Didatismo e literatura", as classes trabalhadoras aparecem dissociadas do "saber" e do "raciocínio", por motivos objetivos - segundo o crítico -, ligados à "desigualdade real" e ao "caráter classicista da cultura". ${ }^{346}$ Quando ele discute os possíveis modos de superação dessa distância socialmente produzida entre a fala "mais racional", apoiada na teoria marxista, e a "intuição" dos operários referida, de modo geral, como uma "salada de superstições, preconceitos, ideologia pequeno-burguesa e experiência cruciais" - $-{ }^{347}$ a mediação política apresenta-se sob a

\footnotetext{
${ }^{341}$ Ibidem, p. 149.

${ }^{342}$ Ibidem, p. 149.

343 “A Santa Joana dos Matadouros”. In: Que horas são?, op. cit., p. 91.

344 "Na periferia do capitalismo" (entrevista). In: Martinha versus Lucrécia, op. cit., p. 304.

${ }^{345}$ Pécaut, Daniel. Os intelectuais e a política no Brasil: entre o povo e a nação. São Paulo: Ática, 1990, p. 18.

${ }^{346}$ Ibidem, p. 149.

${ }^{347}$ Ibidem, p. 149-50.
} 
chave relativamente estrita da organização de vanguarda leninista. Ou seja, considerase que é a "prática partidária, que retém e liga, na sua diferença, a consciência real do operário e as proposições marxistas, e quer fundi-las por força da atividade e do esclarecimento". ${ }^{348}$ Assim, a ponte entre o estado brutal de exclusão social e a perícia político-ideológica - o "desequilíbrio convergente entre cabeça e coração", nos termos de Paulo Arantes - seria introduzida desde fora das camadas subalternas, ${ }^{349}$ de modo a romper as malhas da reificação e articular a crítica à consciência de classe, prática por definição. Desse modo, Schwarz argumenta que a modernização capitalista reservaria às classes subalternas um lugar "atual" e outro "virtual", sendo esse último um estágio pós-burguês embutido de algum modo na ordem mercantil existente, de maneira que os dois momentos estão "mais ou menos ligados, conforme o nível da consciência e da luta de classes", nos seus termos. ${ }^{350}$

Para Schwarz, sem o reconhecimento "científico-prático" desse antagonismo "virtual”, em gestação histórica - que supõe a ação de uma força de trabalho negativa engendrada no sistema produtor de mercadorias, com potencial para angariar um poder de veto decisivo na dinâmica de acumulação -, a crítica recairia numa visão moral do mundo, ainda que tenha ambição anticapitalista. Nesses termos, o sistema de normas e práticas próprias a uma racionalidade de governo, por meio do qual se expande o capitalismo, é estranho ao senso histórico oposicionista do texto. A ação de governar ora é vista, fundamentalmente, como violência e coerção, ora tende - no limite - à própria supressão (a depender do conflito de classes). Seja como for, o próprio Schwarz afirma que esse ensaio, "até aqui, não passa de escrita dogmática". ${ }^{351}$ E ele reconhece que, caso o compromisso com os trabalhadores se impusesse como critério de modernidade no país, seria necessário inventar formas culturais, sociais e estéticas - com vistas à organização política dos pobres -, o que passava, na sua faixa de atuação, pela redefinição mesma do que seja crítica imanente de formas artísticas autonomamente configuradas. Essa ampla perspectiva teórico-política anuncia-se, mas não se pôde realizar, nas páginas de "Didatismo e literatura".

\footnotetext{
${ }^{348}$ Ibidem, p. 149.

349 A referência à "articulação negativa de cabeça e coração" sob o regime de mercado formula-se nos textos de Schwarz em "Dinheiro, memória, beleza (O Pai Goriot)". In: A Sereia e o desconfiado, op. cit., p. 176. Cf. Arantes, Paulo. O fio da meada. Rio de Janeiro: Paz e Terra, 1996, p. 209.

${ }^{350}$ Ibidem, p. 149.

${ }^{351}$ Ibidem, p. 150.
} 


\section{Hipótese armada e abismo histórico}

Uma boa amostra histórica sobre como esse "caldo de cultura militantista" se fazia presente no raciocínio do crítico encontra-se, ${ }^{352}$ por exemplo, na divergência entre Schwarz e a sua ex-professora Gilda de Mello e Souza, a respeito da peça Arena conta Tiradentes (1967), de Boal e Guarnieri. A pedido de Schwarz, Gilda escreve para a Teoria e Prática um ensaio sobre as técnicas de caracterização do povo em Terra em transe (1967), no qual "tudo é seco e rápido como uma execução". ${ }^{353}$ No exame do filme-chave de Glauber Rocha - e sem desconsiderar o que ela chama de "excessos de retórica" na composição de personagens e ambientes -, Gilda nota como "no meio do povo tudo se torna cortante, as oposições são de preto e branco, não há jogos espetaculares de planos e as cenas se passam mais ou menos no rés do chão".354 Já próximo à conclusão do artigo, ela faz menção à montagem recente do Arena, que aparece como um termo de comparação rebaixado. O seu alvo era a tentativa teatral de revalorização naturalista do herói mítico-popular, apoiada na figuração de um mártir da nacionalidade. Gilda define o tratamento ilusionista e empático concedido ao protagonista pela noção de kitsch melodramático, em oposição à forma de Terra em transe, e sugerindo equivalência direta entre a encenação do Arena e os recursos regressivos da mass-media. Sem discutir o fundamento social dessa dramaturgia, ela vê em Arena conta Tiradentes apenas o gesto malogrado de "elevar à categoria artística o chavão patriótico dos livros de leitura e do quadro de Bernardelli". 355

$\mathrm{Na}$ época, Schwarz considera "unilateral” esse juízo de Gilda. E questiona: "Seria o caso de pensar que a invenção cênica abundante e mordaz podia não excluir uma dose de simplicidade política?" ${ }^{356}$ A discordância não passa, ao menos de acordo com o relato do crítico, pela discussão dos rendimentos épicos - de fato limitados dessa dramaturgia. Schwarz destaca o caráter de conclamação política da peça, que

\footnotetext{
${ }^{352}$ A expressão é de Schwarz. "Altos e baixos da atualidade de Brecht”. In: Sequências brasileiras, op. cit., p. 120.

${ }^{353}$ Nos termos de Gilda, o "burlesco e o satírico são utilizados, mas a violência não será tão ostensiva quanto no primeiro filme (Deus e o diabo na terra do sol) e estará sempre um pouco além da imagem, nas evocações que desperta”. Cf. Mello e Souza, Gilda de. "Terra em Transe". In: Teoria e Prática. São Paulo, 1968, n. 2, pp. 144-5. Ver ainda Xavier, Ismail. "Terra em transe: alegoria e agonia”. In: Alegorias do subdesenvolvimento: cinema novo, tropicalismo, cinema marginal. São Paulo: Cosac Naify, 2012, pp. 62-123.

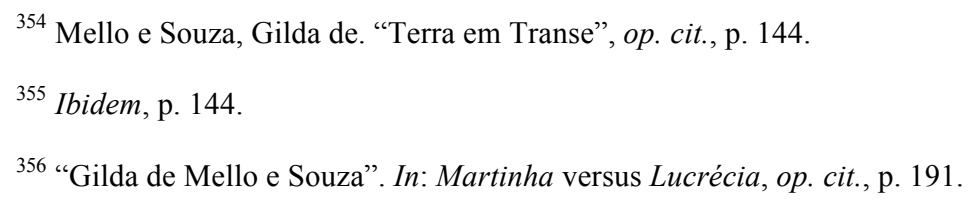


disponibilizaria gestos em equivalência com as práticas vigentes fora do palco, ${ }^{357}$ permeado por uma vaga "ideia" de revolução, quando "não estavam mais visíveis os seus agentes", nos termos da análise de Iná Camargo Costa. ${ }^{358}$ No ano seguinte, o crítico retificaria o seu juízo a respeito do pacto entre cena e vida corrente no Arena pós-golpe, entrevendo na acomodação dual entre Brecht e Stanislavski um "momento ainda incompleto da crítica ao populismo". ${ }^{359}$ No início de 1968, porém, o seu critério de valoração não se circunscreve à falta ou não de consistência interna de Arena conta Tiradentes. De qualquer modo, enquanto Gilda de Mello e Souza entrevia naquele momento - a partir de Terra em transe - certa "obsessão do fim de alguma coisa, que tão cedo não será compensada pelo advento de nenhum acontecimento extraordinário", ${ }^{360}$ a reação de Schwarz, em defesa da função política imediata da peça, encontra-se mais próxima das expectativas projetadas pela passagem da militância clandestina para a guerrilha urbana.

Sob diferentes modos, o entusiasmo agônico que caracteriza essa travessia às armas apresenta-se nas páginas da Teoria e Prática (1967-1968). A maioria do corpo editorial da revista - formado por Schwarz, Ruy Fausto, Sérgio Ferro, os irmãos Sader e João Quartim de Moraes, entre outros - vincula-se à luta política contra a ditadura, seja em organizações favoráveis à tática armada imediata ou não. E esse projeto de uma publicação marxista rigorosa e independente, livre de constrangimentos institucionais e financiada pelo seu comitê de redação - por meio de artigos feitos por militantes não-remunerados - afina-se com a cultura de oposição vigente no período entregolpes, parte dela escaldada pelo desfecho ruinoso das conciliações de classe no pré-1964. Além disso, como se viu, a revista surge num momento específico da trajetória de Schwarz, em que o autor já vinha buscando modos de inserção políticocultural para a sua atividade crítica - alterando-se mesmo a própria composição dos seus materiais de análise -, em interlocução direta com os gêneros públicos, as

\footnotetext{
${ }^{357}$ Ao retomar essa questão em 2006, Schwarz contorna, em parte, a dimensão histórica desse desacordo, pois o episódio lhe serve para evocar o "objetivismo crítico" de Gilda, num elogio à "força educativa da crítica estética", o que relativiza - porém não explica - as bases sociais da divergência. Ibidem, p. 191.

${ }^{358}$ Costa, Iná Camargo. A hora do teatro épico no Brasil, op. cit., p. 138.

${ }^{359}$ Discutindo as limitações ideológicas do Arena, Schwarz opera uma distinção relativa entre o "valor político" de Arena conta Tiradentes - ligado à "simpatia incondicional pelo seu público jovem" e ao seu impaciente "senso de justiça" - e o valor estético ou a "primazia qualitativa" da peça, que não advém como "honra ao mérito" daquelas “formulações mais radicais e justas", segundo ele. "Cultura e política, 1964-1969”, op. cit., pp. 100-1.

${ }^{360}$ Mello e Souza, Gilda de. "Terra em Transe", op. cit., p. 145.
} 
vanguardas políticas e o processo de elaboração intelectual da experiência "populista" anterior, que se tornava objeto de pesquisa na rua Maria Antônia.

A Teoria e Prática é também o desdobramento mais significativo da chamada "segunda geração" do Seminário Marx. Ao lado de Ruy Fausto, Schwarz foi um dos articuladores iniciais desse grupo de leitura d'O Capital, que se constitui em 1963 e segue após o golpe (quando se interrompem as reuniões do primeiro seminário, com a ida de FHC ao exílio). Sob a pressão de 1964, esse coletivo assume uma disposição mais ativista do que o seu predecessor - atraindo participantes mais jovens, nem todos eles professores -, ${ }^{361}$ mas sem deixar de incorporar a disciplina de análise "estrutural" do texto. ${ }^{362}$ Diferentemente do Seminário Marx, cujas pesquisas iam se estruturando em torno de um eixo interno (as relações entre a herança escravista e a configuração do capitalismo no Brasil), o "Seminário II" não se articula num projeto intelectual comum. Os artigos da revista, publicados entre 1967 e 1968, e os rumos de pesquisa dos autores mostram uma relação menos coesa entre os diferentes esquemas conceituais e complexos temáticos adotados. ${ }^{363}$ Ao mesmo tempo, a orientação política direta do grupo limita e desloca certo "apetite de poder" acadêmicoadministrativo, ${ }^{364}$ que era uma dimensão constitutiva do primeiro seminário. Nos termos de Paulo Arantes, a Teoria e Prática apresenta, "pela primeira vez, a face

\footnotetext{
${ }^{361}$ Segundo Schwarz, o grupo incluía a historiadora Emília Viotti da Costa, o arquiteto Sérgio Ferro, os filósofos Ruy Fausto, João Quartim de Moraes e Marilena Chaui, os cientistas sociais Emir Sader, Maria Sylvia de Carvalho Franco, Claudio Vouga, José Francisco Quirino dos Santos, Célia Quirino, Lourdes Sola e Albertina Costa, e a então estudante de medicina Betty Milan. Essa listagem difere um pouco daquela apresentada por Emir Sader, que acrescenta o cientista político Francisco Weffort e o economista Paulo Sandroni, suprimindo Carvalho Franco, Célia e José Francisco Quirino dos Santos. Cf. Schwarz, "Sobre a leitura de Marx no Brasil". In: Nós que amávamos tanto O Capital: leituras de Marx no Brasil. São Paulo: Boitempo, 2017, pp. 18-9. E Sader, "Nós que amávamos tanto o capital - fragmentos para a história de uma geração". In: Sociologias (UFRGS). Porto Alegre, 2005, n. 14, pp. 150-77.

${ }^{362}$ Para uma exposição teórica a respeito, que era utilizada como referência na época, ver Goldschmidt, Victor. "Tempo histórico e tempo lógico na interpretação dos sistemas filosóficos". In: A religião de Platão. São Paulo: Difel, 1963, pp. 139-47. E Guéroult, Martial. Leçon inaugurale: Chaire d'histoire et technologie des systèmes philosophiques. Paris: Collège de France, 1952. Cf. ainda, no âmbito específico do Seminário Marx, Giannotti, José Arthur. "Notas para uma análise metodológica de O Capital". In: Revista Brasiliense. São Paulo, Brasiliense, 1960, n. 29, pp. 60-72.

${ }^{363}$ Ainda faltam balanços de conjunto sobre a experiência do grupo da Teoria e Prática, que poderiam matizar melhor essa afirmação. Além do artigo de Emir Sader, que oferece uma referência parcial sobre o horizonte teórico dos participantes, a historiadora Lidiane Soares Rodrigues discute aspectos do que ela nomeia como "concorrência cúmplice" entre o Seminário Marx e a Teoria e Prática. Ver "Leitores e leituras acadêmicas de Karl Marx (São Paulo, 1958-1964)”. Intelligere. São Paulo, 2016, vol. 2, n. 1, pp. 1-19.
}

${ }^{364}$ A expressão é de Schwarz. Ver “Roberto Schwarz”. In: Retrato de grupo, op. cit., p. 
pública, decidido a intervir na atividade político-cultural, do marxismo uspiano". 365 A revista, porém, teria apenas três edições, mantendo-se por menos de dois anos. O seu comitê editorial é dispersado à força em meio ao Ato Institucional $\mathrm{n}^{\circ} 5$ (AI-5), em dezembro de 1968.

Entre os problemas discutidos na Teoria e Prática, interessa destacar aqui a recepção dada à Revolução na revolução (1967), de Régis Debray, ${ }^{366}$ a partir da qual se pode ver o grupo reagindo, de modo mais direto, à ambiência político-ideológica da época. Sob a chancela incandescente de Che Guevara, cujo prestígio só fazia crescer após a sua morte em 1967, o livro de Debray vinha alcançando uma repercussão significativa, em particular entre os estudantes e a intelectualidade jovem de esquerda. O autor francês, principal teórico do castrismo na década de 1960, tentava converter em emblema a "teoria do foco" guerrilheiro, visando propagar o que ele entendia ser a tática de luta da revolução cubana para toda a América Latina. $\mathrm{Na}$ Teoria e Prática, as primeiras críticas surgem no início de 1968, e são elaboradas por Emir Sader. Ele se volta contra as "generalizações sem conteúdo concreto" de Debray (que, na época de divulgação da obra, encontrava-se preso na Bolívia). ${ }^{367}$ Para Sader, Revolução na revolução seria o sintoma do descompasso entre as estratégias políticas marxistas, premidas por urgências imediatas, e a falta de análises específicas sobre as classes e as formas de reprodução do capitalismo nos países periféricos. Num sentido diverso - e combinando voracidade política e flutuação de paradigmas -, a quarta edição da revista previa elogios de Ruy Fausto à suposta "originalidade epistemológica da obra de Debray", devido à sua interiorização "descontínua" da experiência histórica, tateando-se, desse modo, contribuições de um manual de guerrilha para a reconstrução lógico-filosófica da dialética. ${ }^{368}$

\footnotetext{
${ }^{365}$ Arantes relata a sua experiência de leitura da Teoria e Prática em "Conversa com um filósofo zero à esquerda". In: Zero à esquerda. São Paulo: Conrad, 2004, pp. 268-9. A citação encontra-se em "Falsa consciência como força produtiva". In: Um departamento francês de Ultramar, op. cit., p. 295.

${ }^{366}$ Debray, Régis. Revolução na revolução. Havana: Casa de las Americas, 1967.

${ }^{367}$ Diz Sader: "Se em países como Cuba, Peru ou Guatemala, as capitais e os grandes centros podem sucumbir ao peso de um cerco no campo, o mesmo não parece valer para Argentina, Brasil ou Uruguai, por exemplo. Aqui, o critério que decide o poder é o da conquista social e política dos centros urbanos, e mais particularmente da classe operária, definindo o papel das outras formas políticas, violentas ou não, em função dessa conquista". Cf. “América Latina: Os caminhos da longa marcha”. In: Teoria e Prática, n. 3, op. cit., pp. 136-46.

${ }^{368}$ A informação de que esse artigo de Ruy Fausto constava na quarta edição da revista é de Paulo Arantes. No final de 1968, o quarto número é entregue para a gráfica, mas Schwarz seria impedido pela polícia de retirar as provas para revisão. Não restou documentação histórica sobre essa última edição. O ensaio de Fausto seria publicado sob o título "Sobre o destino da antropologia na obra de maturidade de Marx". In: Marx: Lógica e
} 
Em meio a essas teorizações divergentes, em que as tentativas recentes de foco guerrilheiro não comparecem como objeto concreto de análise, ${ }^{369}$ editores da revista já se envolviam diretamente na preparação da entrada na luta armada. Esse era o caso de Sérgio Ferro, ligado à dissidência comunista de Carlos Marighella ainda antes do seu rompimento com o PCB. Diretor responsável pela Teoria e Prática nos dois números iniciais - deixando o posto quando se torna mais visado pela polícia -, ${ }^{370}$ Ferro alinha-se à Ação Libertadora Nacional (ALN) logo após o seu surgimento, na metade final de $1967 .{ }^{371} \mathrm{E}$ participa, entre outras ações diretas, do primeiro ataque a bomba promovido pela esquerda armada em São Paulo, contra o Consulado dos Estados Unidos, em março de 1968. Segundo Ferro, nesse momento, os seus estudantes "pouco a pouco foram sumindo" das salas de aula. "Acabou se tornando uma situação totalmente insustentável... Ficava ali fechadinho como professor falando e os alunos morrendo", afirma. ${ }^{372}$ Nos debates na rua Maria Antônia, Ferro se via ainda às voltas com críticas aos textos de Marighella, considerados "muito imprecisos do ponto de vista "Marx", segundo os seus termos. Ou seja, "não eram o apelo à classe operária, aos camponeses, somente, mas também às donas de casa, todo mundo", diz ele. "A esperança era que chegássemos a uma sociedade socialista. Mas o momento era muito mais de resistência". 373

Nesse círculo social próximo a Schwarz, é muito importante ainda a trajetória de radicalização política de João Quartim de Moraes. Entre 1965 e 1967, Moraes

Política. São Paulo: Brasiliense, 1987, v. 1, p. 231. Cf. Arantes, “O bonde da filosofia”. In: Um departamento francês de Ultramar, op. cit., pp. 48-9 e 303-7. Entrevista ao autor, op. cit. ${ }^{369}$ Ao discutir a originalidade da prática revolucionária cubana e da estratégia da base móvel de guerrilha, Fredric
Jameson argumenta que esse modelo teria se exaurido na América Latina com a derrota dos movimentos
guerrilheiros no Peru e na Venezuela, ainda em 1966 . Na sua periodização, esses fracassos são acompanhados por
um "desinvestimento da libido e do fascínio revolucionários de uma esquerda do Primeiro Mundo, que retornou
(com algum fermento do maósmo, mais recente) à sua própria 'situação vigente' com o movimento norte-
americano contra a Guerra do Vietnã e os sucessos de Maio de 1968 ". Cf. "Periodizando os anos 60 ". In: Hollanda,
Heloisa Buarque de (org.). Pós-modernismo e politica. Rio de Janeiro: Rocco, 1992, p. 117.

${ }^{370}$ Nesse momento, a repressão prende homônimos de Sérgio Ferro, segundo o seu relato. Ele é detido e torturado pela Operação Bandeirantes (Oban) em dezembro de 1970. E, em 1972, exila-se na França. Ver "Entrevista com Sérgio Ferro" (concedida a Rodrigo Kamimura). In: Revista Risco. São Carlos-SP, 2013, n. 17, p. 140.

${ }^{371}$ A ALN, que se torna o principal grupo da esquerda armada, decide pela luta de guerrilha ainda em 1967, sem se identificar como organização revolucionária. Um dos marcos é o retorno de Carlos Marighella ao Brasil, em agosto de 1967, após participação na I Conferência da Organização Latino-Americana de Solidariedade (Olas), realizada em Havana. Para a Declaração Geral da Olas, que passava a considerar a tática de guerrilha como a única forma de luta efetiva contra o imperialismo, ver Löwy, Michael (org.). O marxismo na América Latina: uma ontologia de 1909 aos dias atuais. São Paulo: Fundação Perseu Abramo, 1999, pp. 303-14.

\footnotetext{
372 "Entrevista com Sérgio Ferro", op. cit., p. 142.

${ }^{373}$ Ibidem, pp. 142-3.
} 
havia cursado uma especialização em filosofia antiga na França, redigindo um estudo althusseriano sobre a "definição de tempo na física de Aristóteles". ${ }^{374}$ Nesse período, ele trava contato em Paris com militantes brizolistas que haviam tentado a resistência armada após o golpe. Além disso, antes de retornar ao Brasil, em março de 1968, Moraes conhece as referências político-teóricas dos grupos intelectuais e estudantis que - apenas dois meses depois - iriam compor as mobilizações de maio na França. Schwarz lembra que o colega voltou "em grande forma", dominando a "política de extrema esquerda, cujos temas e expoentes conhecia no detalhe", e decidido a "tomar responsabilidades revolucionárias". ${ }^{375}$ Para ele, Moraes era uma presença políticointelectual que "fazia o mundo respeitável subir pelas paredes". ${ }^{376} \mathrm{O}$ filósofo uspiano integra a direção do grupo que viria a receber o nome de Vanguarda Popular Revolucionária (VPR), resultado da união da dissidência armada da Polop (Organização Marxista Revolucionária - Política Operária) e de egressos do brizolista Movimento Nacionalista Revolucionário (MNR), em sua maioria ex-sargentos e marinheiros. A nova organização tinha a liderança do ex-sargento do Exército Onofre Pinto, um dos primeiros articuladores da luta armada em São Paulo.

Nas reuniões da comissão editorial da Teoria e Prática, Schwarz pode se ver por um breve período de tempo - como uma espécie de dialeticizador das divergências internas. Ele afirma que uma das suas prioridades era pôr em relação os vários grupos oposicionistas que se postulavam, por vezes, enquanto forças antagônicas. Nas suas palavras, tratava-se de "fazer com que o pessoal conversasse, em vez de não conversar". ${ }^{377}$ No entanto, quando a luta política passava ao enfrentamento direto contra a ditadura, ele próprio conclui pela necessidade histórica de pegar em armas. Sob olhar retrospectivo, Schwarz traduz assim a sua decisão política: "Eu achava que, num sentido muito elementar, as pessoas que eu estimava tinham optado pela luta armada. E as pessoas que eu não estimava eram muito contra. Então, fiquei com as

\footnotetext{
${ }^{374}$ Cf. Santos, Idelette Muzart-Fonseca dos; Rolland, Denis. Le Brésil des gouvernements militaires et l'exil, 19641985. Violence politique, exil et accueil des Brésiliens en France: témoignages et documents. Paris: L'Harmattan, 2008, pp. 69-70.

${ }^{375}$ Desse modo, diz Schwarz, "quando os jornais começaram a dar notícia da nova insolência contestatária dos estudantes franceses, nós já tínhamos familiaridade com o fenômeno". Cf. "Maio de 1968: Fernando Henrique Cardoso, José Arthur Giannotti, Luiz Felipe de Alencastro, Paulo Arantes e Roberto Schwarz" (entrevista a Ricardo Musse). In: Schwartz, Adriano (org.). Memórias do presente. São Paulo: Publifolha, 2003, pp. 455-6.

${ }^{376}$ Ibidem, pp. 455-6.

${ }^{377}$ Entrevista ao autor, op. cit.
} 
pessoas que eu achava que eram as melhores, mas eu era cético". ${ }^{378}$ Ele afirma que considerava "remota" a tese de que a deflagração da guerrilha - desprovida de radicação social prévia - poderia incorporar apoio político até a conquista do aparelho do Estado. Seja como for, em meados de 1968, o autor confia que uma força estratégica móvel, dotada de autonomia político-militar e constituída inicialmente por um pequeno núcleo de militantes, poderia explicitar - mediante ataques bempreparados - a imagem de um país “ingovernável” (a expressão é dele), impondo recuos táticos da ditadura. ${ }^{379}$

A esse respeito, é bastante conhecida a tese principal de "Cultura e política, 1964-1969”. Inovando em várias frentes no exame da produção artística e cultural do período, o ensaio busca explicar, afinal, os termos desse processo histórico que estaria proporcionando a conversão do intelectual à militância armada no país. Nesse sentido, Schwarz demonstra que, após 1964, surge aqui uma cultura de esquerda mal acomodada, que ele define como uma "floração tardia" e anômala da experiência anterior de "Aufklaerung popular", ${ }^{380}$ que dava frutos quando era suprimido mediante terror policial - o seu chão histórico. A ditadura cortava os laços entre as classes subalternas e os intelectuais, mas o movimento cultural não seria inicialmente reprimido. Desse modo, o trabalho de experimentação artística, que vinha se orientando a partir de critérios de transformação nacional e de classe, sofre um deslocamento objetivo. O que se vê, então, é uma cultura do contra que produz para consumo próprio, sem alcançar o seu destinatário político. E, no interior mesmo dessa esfera social restrita, marcada pela impotência prática, fermenta-se uma "geração maciçamente anticapitalista", 381 que elabora a crítica às conciliações populistas e, parte dela, mostra-se disposta a resistir pelas armas. Nesse ensaio, redigido no exílio entre outubro de 1969 e fevereiro de 1970, Schwarz fala em “crise aguda" da

\footnotetext{
${ }^{378}$ Entrevista ao autor, op. cit.

${ }^{379}$ Segundo Schwarz, "no melhor dos casos, quem teve uma formulação interessante foi o Marighella, que disse: 'A gente pode tornar isso aqui ingovernável'. Quer dizer, a ideia de que é ingovernável e aí, mal ou bem, seria preciso fazer um acordo pra tornar o país governável outra vez, e restabelece a democracia. Em relação à ideia de que os grupinhos iriam crescer e implantar o socialismo, eu era muito cético. E agora, visto à distância, acho que foi um erro". Ao mesmo tempo, o autor destaca a ausência de contraponto intelectual às teses de Marighella. "Se houvesse um intelectual com força pra se opor ao Marighella, dizendo 'isso é uma loucura o que você está fazendo’, teria sido muito melhor. Mas não havia”, afirma. Entrevista ao autor, op. cit.

380 “Cultura e política, 1964-1969”, op. cit., p. 106.

${ }^{381}$ Ibidem, p. 72.
} 
intelectualidade no Brasil, pressionada pela escalada repressiva à direita e, noutro sentido, por uma "enorme difusão da ideologia guerreira e voluntarista". ${ }^{382}$ Ante o baixo "prestígio da escrivaninha", ele formula o problema: "Se a sua atividade (do intelectual), tal como historicamente se definiu no país, não é mais possível, o que lhe resta senão passar à luta diretamente política?"383

A expectativa schwarziana de traduzir em força material a "relativa hegemonia cultural da esquerda" no período - conforme exige a luta política -, ${ }^{384}$ parecia encontrar bases sociais em 1968. Após o assassinato pela polícia do estudante secundarista Édson Luís Lima Souto, em março daquele ano, voltam a eclodir protestos de massa nas capitais do país. Apoiados nos estratos sociais médios, os estudantes ascendem como o único movimento de oposição a se rearticular nacionalmente após o golpe, dando demonstrações de força que culminam na "Passeata dos 100 mil", realizada no dia 26 de junho, no Rio de Janeiro. Além dos enfrentamentos de rua, havia outros fatores internos que contribuíam para insuflar o clima de agitação política (e a hipótese da via insurrecional). O ambiente conspirativo e difuso próprio à luta clandestina - dissociada das camadas populares -, a repercussão midiática das ações de "propaganda armada" da revolução (sem baixas significativas) e a superioridade tática passageira dos militantes, dada a desarticulação inicial das forças repressivas, configuram nesse momento o que o sociólogo Marcelo Ridenti chama de "parecer poder" dos grupos armados. ${ }^{385}$ Quartim de Moraes, por exemplo, afirma que a disputa pelo domínio das ruas foi uma "agradável surpresa" para as organizações guerrilheiras, ${ }^{386}$ que, àquela altura, já haviam definido o seu núcleo político (como a ALN e a VPR) e estavam voltadas às primeiras ações diretas.

\footnotetext{
${ }^{382}$ Ibidem, p. 106.

${ }^{383}$ O editorial da segunda edição da revista Aparte, publicada pelo Teatro da USP em maio de 1968, repercute um juízo similar. Nesse texto, afirma-se: "Estamos em guerra. Não somos nós, tão pouco afeitos que somos às coisas militares, que o afirmamos. (...) Acuados e desarmados numa guerra que de repente sabemos estourada há muito, que é que podemos fazer com a palavra escrita? (...) Iremos tão longe quanto acharmos necessário. Não nos cabe a função de auto-censores. Que se dê à polícia o que é dela". Ante essa "guerra total", em que o inimigo a ser eliminado é interno, o editorial faz valer de modo direto o chamado às armas de Régis Debray, segundo o qual o "intelectual deve suicidar-se como categoria social, para renascer como revolucionário". No primeiro semestre de 1968, Schwarz colabora na montagem d'Os Fuzis da Dona Tereza Carrar, dirigido por Flávio Império, que tenta dar forma teatral a essas premissas políticas. Cf. "Proposta sobre a crítica e a produção artística". In: Aparte. São Paulo: Tusp, mai./jun. 1968, n. 2, pp. 3-4. E “Cultura e política, 1964-1969”, op. cit., pp. 106-7.

384 “Cultura e política, 1964-1969”, op. cit., p. 71.

${ }^{385}$ Ridenti, Marcelo. O fantasma da revolução brasileira. São Paulo: Editora Unesp, 2010, p. 53.

${ }^{386}$ Essa afirmação de Quartim de Moraes foi feita em entrevista a Marcelo Ridenti. Ibidem, p. 50.
} 
$\mathrm{Na}$ bibliografia existente, uma das únicas referências à participação de Schwarz nos inícios da luta armada encontra-se em Iara: uma reportagem biográfica, da jornalista Judith Patarra. Essa obra acompanha a trajetória da militante Iara Iavelberg, que foi professora-assistente na USP e companheira de Carlos Lamarca, e seria assassinada pela ditadura em 1971. Num trecho do livro, registra-se um encontro clandestino da guerrilha, realizado no final de 1968, e que teve a presença do crítico:

\begin{abstract}
A situação econômica, entretanto, melhorava para a classe média. Os economistas simpatizantes apontaram: o produto interno bruto cresce, a inflação de $25 \%$ ao ano é igual à de 1967. As exportações aumentam graças aos incentivos, crédito especial e redução de impostos sobre o lucro. Aumenta a concentração de renda, que traz crescimento agrícola e industrial. (...)

Roberto Schwarz ensaiou expor a análise dos economistas numa reunião da VPR. Não queriam saber. Negavam a realidade, habitantes de um Brasil próprio.

- Quase me mataram. ${ }^{387}$
\end{abstract}

A despeito do caráter sumário e meio sobrecarregado do relato, a referência a essa intervenção hesitante e logo abortada de Schwarz, que tenta expor algo sobre o modo ambivalente de reprodução do capitalismo no país - num momento em que campeia violência contrarrevolucionária e retomada da acumulação econômica -, esboça o lugar ocupado pelo crítico nos espaços de deliberação da guerrilha. De fato, Schwarz não chegou a ser um formulador político nas organizações armadas. Ele diz que era um "soldado raso". ${ }^{388}$ De todo modo, a essa narrativa parcial de Judith Patarra, caberia acrescentar também os pontos de convergência - então vigentes - entre o autor e as avaliações da guerrilha. Schwarz acredita, ao menos até o final de 1970, que os militares haviam imposto uma espécie de "tampa (...) em cima de um caldeirão", 389 que ainda estaria fervilhando sob as molas da repressão. Em “Cultura e política, 19641969”, afirma-se: “Calado à força, o país está igual, onde Goulart o deixara, agitável como nunca". ${ }^{390}$ Assim que esse bloqueio temporário fosse desfeito, dizia ele, viria à

\footnotetext{
${ }^{387}$ Patarra, Judith. Iara: uma reportagem biográfica. Rio de Janeiro: Rosa dos Tempos, 1993, p. 271.

${ }^{388}$ Entrevista ao autor, op. cit.

389 “Entrevista com Gildo Marçal Brandão e O. C. Louzada Filho”, op. cit., p. 103.

390 “Cultura e política, 1964-1969”, op. cit., p. 107.
} 
tona a "maré fantástica da insatisfação popular". ${ }^{391}$ Em 1970, quando o autor discute aspectos de uma modernização econômica que caminha à revelia das expectativas do nacionalismo de esquerda, o seu raciocínio opera a partir do pressuposto de que seria inviável a combinação entre a miséria social e a constituição de uma sociedade de consumo no Brasil, o que seria desmentido pela ditadura.

No momento em que ocorria essa discussão no interior da guerrilha, referida por Judith Patarra, a barbárie do aparelho empresarial-militar incidia diretamente sobre a faixa universitária de classe média. A Faculdade de Filosofia da USP, ocupada desde julho pelos alunos - e sob o processo de implementação dos comitês pela direção departamental paritária -, é bombardeada e incendiada no início de outubro, precipitando-se a tendência restrita de conversão às armas. Schwarz, por sua vez, já havia sido procurado pela polícia "um par de vezes". ${ }^{392}$ Assim, pouco antes da decretação do AI-5, ele decide sair de cena, refugiando-se em casas de amigos. O seu período de reclusão, que vai de dezembro de 1968 a abril de 1969, coincide com o início das quedas em série de militantes ligados a grupos de oposição. É nesse momento que se multiplicam os relatos sobre execuções sumárias, desaparecimentos forçados e também sobre a centralidade da prática de tortura como política de Estado. A historiografia registra mesmo uma "enxurrada de prisões" nos três primeiros meses de 1969 - entre elas a de Onofre Pinto, a principal liderança da VPR -, produzindo "consequências destruidoras" para a incipiente luta armada. 393

Schwarz acompanha perplexo a crônica das quedas, que lhe pareciam tomar uma proporção "avassaladora e absurda", indicando a fragilidade e o despreparo da resistência armada, numa "subestimação incrível” da ofensiva do adversário, segundo os seus termos. "As pessoas mais próximas a mim começaram a ser presas. Era evidente que, em seguida, eu ia ser preso", afirma ele. ${ }^{394}$ Desde o final de 1968, o seu colega João Quartim de Moraes, considerando o refluxo das mobilizações sociais e as proporções inauditas do que ele chamava de "terrorismo de Estado", defendia "limitar a um mínimo indispensável as ações armadas”, algo que já era visto como um recuo

\footnotetext{
${ }^{391}$ Ibidem, p. 107.

392 "Roberto Schwarz". In: Retrato de grupo, op. cit., p. 237.

${ }^{393}$ Gorender relaciona a sequência de prisões entre janeiro e março de 1969 ao desmantelamento de um aparelho da VPR em Itapecerica da Serra (SP) e às delações obtidas sob tortura. Cf. Combate nas trevas, op. cit., p. 135.

${ }^{394}$ Entrevista ao autor, op. cit.
} 
impossível e inaceitável. ${ }^{395}$ Em janeiro de 1969, ele é expulso da VPR. ${ }^{396}$ Em meio à escalada assassina do aparato repressivo, Schwarz recebe o convite para ser "profissionalizado" na luta armada. ${ }^{397}$ A proposta significava assumir em tempo integral a militância clandestina, incorporando-se ao "grupo de fogo" - envolvido diretamente nas ações armadas -, sob um isolamento social ainda mais rígido, e com riscos crescentes de prisão, morte e tortura. Quando essas possibilidades históricas se "colocaram na lata mesmo", e num momento em que parte dos seus companheiros que tinham feito a opção militar estavam sendo presos, Schwarz decide ir embora do país. ${ }^{398}$ Em abril de 1969, ele se encaminha para o exílio na França.

Num contexto parcialmente corroído por reveses precoces, esses processos de evasão tendiam a assumir um potencial litigioso evidente. Assim como outros militantes que desertaram face à situação de cerco e aniquilamento da oposição, Schwarz tinha conhecimento sobre as táticas de ação e as identidades daqueles que optaram por seguir na guerrilha. Na ocasião, ele busca uma saída independente, sem "dever nada" à organização - segundo a sua expressão -, rejeitando os contatos e o apoio financeiro oferecido pelo grupo para cruzar a fronteira. Assim, visava mitigar também a pressão pela continuidade da sua militância no exterior. De qualquer maneira, ao desembarcar em Paris, o autor encontra parte da comunidade brasileira empenhada em "continuar a fazer a luta armada da Europa", segundo os seus termos. ${ }^{399}$ Ele procura tomar distância desse anseio. "Tirei o time (de campo) e fui fazer um programa de trabalho. (...) No exílio, se você se mete nas coisas, enlouquece, começa a fazer revoluções de fantasia", afirma. "Eu estava com muita coisa na

\footnotetext{
${ }^{395}$ Quartim de Moraes, João. “A mobilização democrática e o desencadeamento da luta armada no Brasil em 1968: notas historiográficas e observações críticas”. In: Tempo social. São Paulo, 1989, vol. 1, n. 2, p. 156.

${ }^{396}$ Sob a iminência do extermínio da guerrilha, também proliferam os ressentimentos mútuos entre setores da militância armada e parte da intelectualidade simpática à ideia da revolução. Numa passagem do diário de Carlos Lamarca, escrita um mês antes da sua execução, anota-se: "Glauber Rocha declarou-se auto-exilado em Londres, também falou (...) que a ditadura institucionalizou a violência. Declarou ainda ser impossível trabalhar no Brasil, que a revolução é inevitável e que é um dos precursores dela (sic) - a intelectualidade é sempre assim, para no caminho: 'já deu tudo', ou seja, nada". Cf. Lamarca, Carlos. "O diário de Lamarca". In: Folha de S. Paulo. Folhetim, 06 ago. 1971, p. 10.

${ }^{397}$ Entrevista ao autor, op. cit.

${ }^{398}$ Entrevista ao autor, op. cit.

${ }^{399}$ Em Paris, por exemplo, o coletivo reunido em torno da revista Debate - que incluía alguns ex-companheiros de Schwarz, entre eles Quartim de Moraes - reconheceria publicamente apenas em 1972 que a luta armada estava derrotada, verificando-se um "cortejo de desilusões, de desânimo e de desesperança". Cf. o editorial "Atualidade do leninismo". In: Debate. Paris, abr. 1972, n. 9, p. 3. Entrevista ao autor, op. cit.
} 
cabeça, e aqui totalmente impossibilitado de escrever" ${ }^{400}$ Logo nos três primeiros anos de exílio, Schwarz finaliza a peça A lata de lixo da história (1969), iniciada no Brasil, e redige "Cultura e política, 1964-1969" (1970) e "As ideias fora do lugar" (1972), que marca a sua passagem para as pesquisas machadianas da maturidade. Nesse período, entre 1969 e 1972, são militarmente dizimados os últimos grupos de guerrilha urbana no Brasil. Após o fracasso da política de conciliação de classes pré1964, estava suprimida também a alternativa de oposição pelas armas.

${ }^{400}$ Entrevista ao autor, op. cit. 


\section{Depois do fim de linha}

$\mathrm{Na}$ orelha da edição mais recente d'O pai de família, que reúne parte dos ensaios de Roberto Schwarz elaborados nos anos 1960, afirma-se que textos como "O cinema e Os fuzis" (1966), "Didatismo e literatura" (1968) e "Cultura e política, 19641969” (1970) não pretendem “alardear posições inabaláveis”. Segundo a apresentação da obra, esses escritos têm por fim "promover deslocamentos - conceituais, políticos e estéticos", algo que "deve ter parecido paradoxal e mesmo irritante" num contexto histórico de "polaridades irredutíveis, na cultura como na política". Assim, ainda de acordo com esse material de divulgação, a crítica de Schwarz aproxima-se do que havia de "mais vibrante na cultura brasileira contemporânea", isto é, a "dramaturgia do Arena e do Oficina, o cinema de Glauber Rocha, a música de Caetano Veloso e a ficção de Paulo Emílio Sales Gomes”. A partir desses objetos, o crítico teria elaborado uma "prosa de invenção", em que se reconhece a "sintaxe adorniana", e é escrita "à maneira de um Brecht baiano, brasileiro mas dialético". ${ }^{401}$ Num ritmo indisfarçado de equivalência geral, e sob horizonte de expectativas rebaixado, esses comentários liquidam o componente político que, a partir de vários limites objetivos, começava a reorientar a trajetória intelectual do autor, aspecto que se tentou acompanhar na parte final desta tese.

Noutro registro histórico, a primeira revisão crítica direta sobre esses textos pré-exílio seria elaborada por Schwarz. Numa nota escrita em 1977, e inserida como abertura de "Didatismo e literatura" (por ocasião da sua publicação em livro), ele se declara mesmo "abismado" com as ideias que faziam a sua cabeça por volta de 1968. ${ }^{402}$ O crítico parte, aqui, do diagnóstico de uma contradição entre o seu propósito "antidogmático" e mesmo "cordato" - segundo ele -, e o "vanguardismo esquemático" que teria, afinal, sustentado o seu quadro político-conceitual anterior. ${ }^{403}$ Esse suposto descompasso, que Schwarz remete a um sintoma de época, seria caracterizado - entre outros aspectos - pela "utilização escolástica da terminologia marxista”, que teria sido

\footnotetext{
${ }^{401}$ A última edição d'O pai de família e outros estudos é publicada em 2008. No seu texto de apresentação nãoassinado, citado aqui entre aspas, apenas o trecho referente ao "Brecht baiano" seria retirado da orelha do livro. Essa referência, entretanto, permanece na versão que se encontra no site da Companhia das Letras. Disponível em: https://www.companhiadasletras.com.br/detalhe.php?codigo=12366. Acesso em: 17 nov. 2018 (grifos do autor).

402 “Nota, 1977”. "Didatismo e literatura” (Um folheto de Berhta Dunkel). In: O pai de família, op. cit., p. 55.

${ }^{403}$ Ibidem, pp. 55-6.
} 
alheada do processo histórico real, por uma sideração igualmente abstrata na cientificidade "em geral" - atribuída à influência do positivismo de Althusser - e por certa incorporação enviesada da política leninista, que supõe a ação de um partido de vanguarda que deve estruturar a consciência de classe. ${ }^{404}$ Somando-se tudo, pergunta ele, "como explicar tamanho bitolamento?"405

Schwarz busca ressaltar o resultado prático e ideológico do seu ensaísmo em 1968. De um lado, segundo o autor, teriam se constituído os "detentores da competência científica e literária", desprovidos de eficácia material. Noutro campo, as "massas, que têm a força, mas são confusas". Assim, "a união dos dois restabeleceria a unidade perdida”, nos seus termos. ${ }^{406}$ A analogia irônica distancia o problema que a nota quer definir. Diz ele: "Ciência e arte estão prontas e acabadas, e cabe ao povo mudar - o que fará graças ao intelectual progressista, que enquanto teórico tem a caução da miséria popular, e enquanto dirigente se apoia na autoridade da ciência que falta a seus dirigidos". ${ }^{407}$ Desse modo, e voltando-se contra a "teleologia otimista", o "vanguardismo" e o "esquematismo" do pensamento de esquerda na época - conceitos que, tomados em termos absolutos, fariam carreira em parte da bibliografia posterior sobre os anos 1960 -, a sua visão retrospectiva não entra em confronto específico com o processo social brasileiro às voltas com 1968. Além disso, embora Schwarz afirme de passagem que o seu objetivo, na época, era "dialeticizar" o antagonismo entre "as letras engajadas e as formalistas", o problema não é desenvolvido aqui. ${ }^{408}$

Entre 1964 e 1968, conforme se tentou verificar nesta tese, Schwarz reformula em parte os seus próprios procedimentos críticos anteriores, nos quais a postulação de certa indissociabilidade entre obra autônoma e crítica dialética era adotada como um horizonte último para a sua intervenção no contexto histórico brasileiro. Após o golpe empresarial-militar, esse quadro de inteligibilidade estética e histórica seguiria ativo, mas o autor experimenta meios para operar de modo mais direto com a sua imediatidade prática, num momento em que as "transfusões da experiência" entre as

\footnotetext{
${ }^{404}$ Ibidem, pp. 55-6.

${ }^{405}$ Ibidem, p. 55.

${ }^{406}$ Ibidem, p. 56.

${ }^{407}$ Ibidem, p. 56.

${ }^{408}$ Ibidem, p. 55.
} 
classes eram enquadradas pela gestão diretamente armada da vida social brasileira. Esse percurso contraditório - com resultados críticos heterogêneos e objetivamente limitados - é a presença ausente na sua "Nota, 1977", que, embora carregue no título o ano da sua escrita, não faz menção ao estágio atual dos vínculos entre teoria e prática. Desse modo, as objeções incisivas do crítico contra o "bitolamento" ideológico do jovem Schwarz também respiram um ar histórico rarefeito, em que se entrevê o custo objetivo do truncamento da hipótese da revolução no Brasil.

Segundo Schwarz, essa nota teria sido escrita sob o impacto de uma visita ao Brasil, realizada em 1977. Na ocasião, ele vinha sondar as condições políticas para o seu retorno definitivo, que ocorreria no ano seguinte, num momento em que a luta contra a ditadura começava a sair da clandestinidade. Sobre esse reencontro com o país, após nove anos de exílio, ele relata as suas primeiras impressões: "Quando eu cheguei, fui ver um amigo, e ele nos pôs no seu fusquinha. Demos uma volta e fomos até o Jardim da Luz (em São Paulo), para passear e ver o povo. E ele me chamou a atenção: 'Olha aí, todo mundo com radinho de pilha'. (...) Todo mundo com gadgets. Era uma novidade". ${ }^{409} \mathrm{O}$ crítico diz que se depara ali com "outro universo" social, marcado pela "semi-integração em nível baixo" de uma parcela maior de trabalhadores ao consumo de massas e ao aparato mercantil, com seu lastro parcial de reprodução das estruturas de dominação social. Na síntese de Schwarz, "o esquema básico dos pobres não integrados estava se diluindo" no Brasil, o que reposicionaria em "primeiro plano" a crítica ao fetichismo da mercadoria e aos efeitos da sua generalização. ${ }^{410}$ Ao mesmo tempo, o crítico mantinha a convicção política segundo a qual, para um intelectual "funcionar bem" no Brasil, ele deve considerar que tem o "mandato" tácito dos pobres, de acordo com a formulação de Joaquim Nabuco. 411 "O intelectual de esquerda tem que se sentir obrigado a não só se ocupar dos excluídos como falar em nome deles no âmbito da alta cultura", afirma Schwarz. ${ }^{412}$

\footnotetext{
${ }^{409}$ Entrevista ao autor, op. cit.

${ }^{410}$ Entrevista ao autor, op. cit.

411 “Quando Nabuco disse que ele tinha o 'mandato da raça negra', a raça negra estava fora. (...) Até 1964, já não era o esquema do Nabuco, evidentemente, mas (os pobres) estavam fora num grau muito considerável. E havia o movimento operário organizado, mais populista ou menos populista”, diz Schwarz. Entrevista ao autor, op. cit. Cf. ainda Nabuco, Joaquim. O abolicionismo. Rio de Janeiro: Nova Aguilar, 2000, pp. 66-7.
}

${ }^{412}$ Entrevista ao autor, op. cit. 
Nesse momento, estava em curso uma reacomodação político-ideológica no país. O antigo ideário nacional-popular, refundido, era incorporado por segmentos da indústria cultural, para a qual convergia parte dos intelectuais formados no ambiente contestatário da década anterior. As mobilizações de massa, por sua vez, só eclodiriam com peso político nacional a partir de 1978, com as greves do ABC. A despeito disso - e embora os órgãos coercitivos da ditadura estivessem em pleno funcionamento -, a noção de participação, e as práticas de gestão e controle social a ela associadas, começam a ser absorvidas, de modo paulatino e contraditório, como parte da linguagem e das estruturas do Estado brasileiro. Um exemplo disso ocorria no campo da cultura, no qual a racionalidade governamental vinha ultrapassando a ação estritamente censora e reativa. E começava, então, a "fornecer programas para a intelectualidade, incentivos à produção, agências voltadas para a cultura", que deveria "entrelaçar-se" com o binômio "segurança e desenvolvimento", conforme o Plano Nacional de Cultura (PNC), de 1974. ${ }^{413}$ Nesse contexto, proliferam ataques ao que era entendido como o "substituísmo" dos intelectuais e artistas de esquerda dos anos 1960, que teriam usurpado o lugar da consciência dos operários no enfrentamento ao golpe. ${ }^{414}$ Essas avaliações, que se viam como críticas às formas tradicionais de poder e de autoridade no campo da esquerda, partiam de militantes que, em 1980, iriam aglutinar-se no Partido dos Trabalhadores (PT), sob a expectativa da entrada da classe operária na política brasileira sem a tutela "populista". E essa controvérsia histórica e ideológica, em que o intelectual parecia destituído do "fundamento da sua influência anterior" - considerando o modo como a sua função político-social se legitima no pré1964 -, ${ }^{415}$ não deixa de repercutir também naquela nota feita por Schwarz.

No entanto, por volta de 1968, não é somente a supressão violenta da imediatidade prática que se impõe na trajetória crítica de Schwarz. Nesse momento, também o seu esforço de delimitação histórica de formas estéticas e sociais brasileiras - que vinha atendendo em parte às necessidades da intervenção política - esbarra num

\footnotetext{
${ }^{413}$ Heloísa Buarque de Hollanda e Marcos Augusto Gonçalves discutem aspectos do PNC, no qual se formulam diretrizes para a organização empresarial da cultura no país. Ver "A ficção da realidade brasileira". In: Novaes, Adauto (org.). Anos 70: ainda sob a tempestade. Rio de Janeiro: Aeroplano/Editora Senac Rio, 2005, pp. 110-1.

${ }^{414} \mathrm{Na}$ década de 1990, Schwarz recapitula essa ofensiva ideológica travada no seio da intelectualidade de esquerda, que, "parte por anticomunismo, parte por catolicismo, parte por ouvir os concretistas e parte por uma espécie de purismo melindroso no trato da cultura popular fez do CPC e de suas iniciativas a encarnação mesma do espírito de Stalin (!)". Ver "Pelo prisma do teatro". In: Sequências brasileiras, op. cit., p. 219.

${ }^{415}$ O termo é de Schwarz. Cf. "Nunca fomos tão engajados". In: Sequências brasileiras, op. cit., p. 174.
} 
impasse análogo. O momento em que isso se manifesta de modo mais enfático é no seu ensaio "Sobre o raciocínio político de Oliveiros S. Ferreira" (1967), publicado na Teoria e Prática. Schwarz quer demonstrar aqui que a prosa política de Oliveiros, dotada de teoria compósita e acintosamente desconjuntada, não se desdobra a partir dela mesma, comprazendo-se numa "reunião incômoda de almas inimigas". ${ }^{416}$ A cada parágrafo, diz o crítico, o autor busca soldar - de modo disparatado - lições apanhadas em escritos de Lenin, Trotsky, Gramsci ou Rosa Luxemburgo com chamamentos à "Pátria Grande", aos "Destinos Nacionais" e à "Revolução da Ordem", entre outros universais de igual valor. Sob esse arbítrio associativo, postulados do liberalismo, que propagam o "livre" conflito de interesses entre patrões e trabalhadores no âmbito do mercado, convertem-se mesmo em elogio enviesado à luta de classes, que é destituída de qualquer centralidade político-social. Nessa salada truculenta, os militares figuram, afinal, como os "proletários do sistema", conjugando interesse particular e geral. ${ }^{417}$ Acompanhando a "chispa desembestada" de Oliveiros, ${ }^{418}$ Schwarz enumera uma série de casos de coexistência entre incompatíveis, relativamente afins à "mistura belmiriana" conceituada por ele em 1964. Contudo, essa correspondência histórica não vem à tona no ponto de vista crítico. ${ }^{419} \mathrm{E}$, assim, não se esboça um sistema teórico que aponte a possível unidade interna dessa matéria histórica fraturada.

Esse texto de Schwarz é impulsionado por uma tentativa de demarcação dos desvios conceituais e políticos de Oliveiros em relação à dialética marxista. ${ }^{420}$ Para $\mathrm{o}$ crítico, o decisivo é que essa teoria produz uma torção "a-histórica" da dialética, ${ }^{421}$ apoiada em arquétipos externos, que "progridem para trás", engendrando "arroubos elegíacos-realistas". ${ }^{422}$ Esse vezo logicista da argumentação - que, não obstante, tem ambição materialista máxima - faz supor que o problema esteja no uso enviesado da

\footnotetext{
${ }^{416}$ Schwarz redige a "parte I" do artigo. E Ruy Fausto é o responsável pela introdução e pela "parte II". Em O pai de familia, Schwarz publicaria apenas a sua seção. Schwarz, Roberto; Fausto, Ruy. "Sobre o raciocínio político de Oliveiros S. Ferreira”. In: Teoria e Prática. São Paulo, 1967, n. 1, pp. 98-112.

${ }^{417}$ Ibidem, pp. 99-100 e 102.

${ }^{418}$ Ibidem, p. 104.

${ }^{419}$ Esse problema foi destacado por Paulo Arantes. Ver Sentimento da dialética, op. cit., pp. 57-9.

${ }^{420}$ Na segunda parte do texto, Ruy Fausto também vê a teoria de Ferreira sob o prisma quase exclusivo da questão de método, ressaltando a ação nociva e dissolvente que o "ilusionismo ideológico" do autor teria exercido sobre as categorias marxistas. "Sobre o raciocínio político de Oliveiros S. Ferreira", op. cit., pp. 105-12.

${ }^{421}$ Ibidem, p. 100.

${ }^{422}$ Ibidem, p. 101.
} 
norma social moderna na política nacional das ideias, certa infração unilateral da regra que o crítico se dispõe a combater no presente. Em outros termos, o sentimento de modernidade apresenta-se aqui como algo relativamente estável. E, assim, não se constituem vínculos recíprocos entre o objeto determinado - a prosa política de Oliveiros -, a sua atualidade em movimento, e a matéria histórica que lhe orienta o sentido, marcada pela ambivalência ideológicas das elites brasileiras (que, entre o critério liberal e o pendão oligárquico, não precisavam mesmo optar, como bem demonstraria o trabalho de Schwarz). De qualquer modo, na conclusão desse artigo sobre Oliveiros, o crítico reconhece que "a esperança desta doutrina não está em sua lógica" - cujo déficit, por assim dizer, foi o assunto do ensaio -, mas na "falta de lógica de seus leitores, que pode bem não ser pequena. De modo que a crítica, no caso, não refuta nada". ${ }^{423}$ De fato, o autor seria o primeiro a assinalar as limitações desse texto. Ainda que as objeções ao nacionalismo regressivo de Oliveiros sejam pertinentes, Schwarz considera que a sua crítica deixa escapar o "essencial em perspectiva dialética". Ou seja, não diz "o que aquele pensamento representa de fato na situação política brasileira". 424

Ao mesmo tempo, lidando com um caso escancarado de relação não-orgânica entre vida mental e pressuposto social - numa prosa que busca "forjar a unanimidade dos corações estremecidos, aquém de qualquer crítica da economia política" -, ${ }^{425}$ Schwarz entrevê uma inadequação local da própria crítica da falsa consciência, historicamente tributária do liberalismo como norma do progresso. Num trecho importante do seu ensaio, ele anota: “A mistura característica para o fascismo, de sopa e violência, de ridículo e calamidade, torna difícil uma análise justa. Toda crítica parece excessiva e insuficiente ao mesmo tempo". ${ }^{426}$ De fato, na sua origem, a crítica progressista da ideologia supunha uma dimensão de universalidade social possível ou virtual, por meio da qual se podia operar uma crítica imanente das promessas não cumpridas da sociedade burguesa (igualdade, justiça, liberdade, etc.), a partir do próprio conceito que ela enuncia de si mesma. Essas promessas, portanto, só seriam falsas - e alvos de um desmascaramento de classe - na medida em que se postulam

\footnotetext{
${ }^{423}$ Ibidem, p. 105.

424 “Entrevista com Gildo Marçal Brandão e O. C. Louzada Filho”, op. cit., pp. 97-112.

425 "Sobre o raciocínio político de Oliveiros S. Ferreira", op. cit., pp. 102-3.

${ }^{426}$ Ibidem, p. 104.
} 
como já realizadas na prática. ${ }^{427}$ Ora, como desentranhar essa operação lógico-social, dotada de uma correção interna determinada, a partir do que Schwarz chama de "dialética circular" de Oliveiros? O encaminhamento dado pelo crítico é enérgico, mas não leva longe. Para ele, a teorização de Oliveiros tem fundo moral, não transmite conhecimento e é "perfeitamente vazia de conteúdo histórico", já que os seus termos são "movimentados segundo uma regra simples, superposta a eles, que não corresponde ao problema que eles mesmos propõem". 428

De fato, o que seria entendido como a Ideologiekritik original de Roberto Schwarz, um ponto de vista a partir do qual esse "mesmo chão histórico que barateava o pensamento e diminuía as chances de reflexão (...) devolvia a faculdade crítica com a outra mão, fazendo nossa anomalia expor a fratura constitutiva da normalidade moderna" (segundo a boa síntese de Paulo Arantes), ${ }^{429}$ ganha forma - a partir de 1969 - no momento em que vinha sendo suprimido o equivalente político imediato da crítica schwarziana. No percurso de Schwarz, a conquista dessa perspectiva capaz de apreender a desqualificação crítica e recíproca entre o universal - a norma burguesa moderna - e a sua realização particular no país, orientada pela obra madura de Machado de Assis, ocorre, pela primeira vez, sob o registro tétrico e derrisório da chanchada, na sua peça A lata de lixo da história (1969). Sob o rescaldo repressivo dos protestos de 1968 no Brasil, e quando setores das elites liberais davam suporte direto ou indireto à ofensiva exterminista contra a oposição, a adaptação de Schwarz procura ressaltar, justamente, o aspecto político do conto $O$ alienista (que é, como se sabe, contemporâneo às Memórias póstumas de Brás Cubas). ${ }^{430}$ Para isso, o crítico

\footnotetext{
${ }^{427}$ Esse argumento se apoia na explicação de Paulo Arantes, voltada à forma assumida pela crítica da ideologia na obra de Schwarz. Cf. "Conversa com um filósofo zero à esquerda". In: Zero à esquerda, op. cit., pp. 278-84.

428 "Sobre o raciocínio político de Oliveiros S. Ferreira", op. cit., p. 100.

${ }^{429}$ No seu estudo, localizando a obra de Schwarz no interior da tradição crítica brasileira, Paulo Arantes dá o devido peso ao avanço implicado nessa modalidade de crítica ideológica posta em prática pelo autor. Na época, diz ele, "a esquerda uspiana estava convencida de que a crítica de feitio materialista não poderia ser efetivamente exercida entre nós caso as representações ideológicas em circulação não tivessem continuidade social evidente. E mais, que desconfiar do molde clássico desse vínculo era trazer água para o moinho da direita, não só por comprometer a boa teoria da produção social das ideias mas por reforçar perigosamente o lugar-comum predileto de nossos autoritários, a apologia do 'país real' a ser preservado das elucubrações adventícias, e a consequente ofuscação da moderna dominação de classe, esta sim real”. Ver Sentimento da dialética, op. cit., p. 80 e 89.

${ }^{430}$ A peça, que começa a ser planejada pouco antes da decretação do AI-5 e é redigida no exílio, não será objeto de exame nesta tese. Quando A lata de lixo vem a público na revista Almanaque, Schwarz data o livro de 1969, informando ainda que ele foi "retocado em 1974". Cf. "A Lata de lixo da história (Farsa)". In: Almanaque. São Paulo: Brasiliense, 1977, n. 4, pp. 60-79. Para uma boa discussão sobre os seus procedimentos formais, ver "A lata de lixo da história: chanchada política. Conversa com Roberto Schwarz" (com a participação de Sérgio de Carvalho). In: Revista Terceira Margem, Rio de Janeiro, vol. 18, n. 30, jul.-dez. 2014, pp. 227-43.
} 
opta por um gênero público e interventor. No contexto pós-AI-5, entretanto, marcado pelo recrudescimento da censura e do terror policial, a sua peça concebe-se sem uma função política imediata - diferentemente dos textos publicados na Teoria e Prática, por exemplo -, pois agora já não seria possível sequer encená-la.

Num debate recente, feito por ocasião do relançamento d'A lata de lixo da história, Schwarz definiu a sua peça como uma "espécie de brechtianismo sem lição a dar". ${ }^{431}$ Sem desenvolver propriamente essa noção, ele dizia que, na época, não tinha opinião para onde poderia caminhar a luta social no país. E não estaria apto, portanto, a "ensinar próximos passos". Ainda segundo Schwarz, ao deixar o Brasil em direção ao exílio, em abril de 1969, ele teria a convicção de que a luta armada "estava derrotada". ${ }^{432}$ Seja como for, n'A lata de lixo, o vir a ser imanente projetado nos seus ensaios anteriores, que definia para as camadas subalternas um lugar "atual" e em si ligado à posição no processo produtivo - e outro "virtual" e para si (relacionado às possibilidades da consciência de classe), fica em estado de suspensão histórica. ${ }^{433} \mathrm{O}$ happy end sarcástico e farsesco da peça, deliberadamente sem relação orgânica com a intriga - feito de "pura justiça poética, sem nenhuma verossimilhança", nos termos do autor - ${ }^{434}$ situa-se num epílogo que mal cabe na mediação dessa forma teatral. $\mathrm{Na}$ cena final, redigida entre parênteses, o boneco de escravo desfere uma bofetada contra a classe dominante brasileira. Essa perspectiva literária inconformista, que a obra de Roberto Schwarz saberia escavar sob o decoro machadiano, expressa aqui, de maneira mais ou menos direta, o desejo político do autor. Vai ter resposta. Ao mesmo tempo, o imaginado salto à práxis desloca-se para um ato posterior ao último da peça.

\footnotetext{
${ }^{431}$ Em entrevista, Schwarz discute a perspectiva política da peça a partir de outros termos. Diz ele: "Eu tentava imaginar qual seria o fim disso tudo. (...) Imaginei que o desenlace da reabertura democrática seria conservador. Foi assim que se deu. O Brasil é conservador". Cf. entrevista a Colombo, Sylvia. "Passado remexido: a volta de $A$ lata de lixo da história". Folha de S. Paulo. Ilustríssima, 18 mai. 2014, p. 6. A intervenção de Schwarz citada no texto foi feita em debate sobre A lata de lixo, realizado no dia 6 de agosto de 2014 na FFLCH/USP, com a participação de Priscila Figueiredo, Luiz Roncari, José Fernando de Azevedo e Tales Ab’Saber.

${ }^{432}$ Entrevista ao autor, op. cit.

${ }^{433}$ Cf., por exemplo, "Sobre o raciocínio político de Oliveiros S. Ferreira", op. cit., p. 100. E "Um folheto de iniciação política - Didatismo e Literatura”, op. cit., p. 149.

434 “A lata de lixo da história: chanchada política. Conversa com Roberto Schwarz”, op. cit., p. 235.
} 


\section{ANEXOS}

\section{Tempo de ficar velho (1959)*}

\section{POR ROBERTO SCHWARZ}

Escrever diário significa viver em dois tempos, um dos quais curvado sobre a escrivaninha, recordando. É o que faria o professor Abdias, não fosse ele, assim como seu diário, invenção de Cyro dos Anjos. É dupla, portanto, a distância que temos: o Autor vê Abdias, que vê sua vida.

O relato é feito como se fossem Professor e Autor a mesma pessoa. É sensível, contudo, a sábia presença de Cyro dos Anjos, que determina a posição temporal de seu narrador. Mais claramente: Abdias pode contar, dia a dia, o seu dia anterior; de fato, inúmeras páginas começam por “ontem...”. De outro lado, pode Abdias deixar que passe o tempo, afim de nos dar, em flash-back, a visão global de suas agitações. E Abdias sempre escolhe a perspectiva mais correta - do ponto de vista da boa leitura. Não se trata, é evidente, de uma intrusão, falha do Autor. Sua preocupação é dar-nos um romance, e não um diário tal e qual. Comprovante é o título: apesar da narração em primeira pessoa, na capa do livro objetiva-se o nome central: Abdias. O romance tem Abdias por personagem, e sua vida por trama.

O diário, como estrutura, é uma composição de fragmentos conexos, forma que se presta ao retrato psicológico em profundidade. Entre outras causas, por permitir a constante transparência do presente em direção ao passado, perspectiva cara a Cyro dos Anjos, constitutiva de seus personagens centrais. Abdias tem reminiscências e nostalgias do interior mineiro, de "A estabilidade da vida em Várzea dos Buritis"; ao mesmo tempo, e daí sua complexidade, usa de expressões irônicas e moderníssimas, como "sentimento de menos-valia" - conceito psicanalítico acrescido da alusão à mais-valia marxista. Para completar a figura, considere-se que o Professor preocupa-se com o problema da autoria das Cartas Chilenas, é tímido, sonhador, homo scribena, e não loquena, pai de alguns filhos e agasalho de uma impossível paixão. Trata-se de um tipo já clássico em nossa literatura, o herói mineiro da vida 
menor, de O Amanuense Belmiro, dos poemas de Carlos Drummond de Andrade. Correspondência, como se verá, também geográfica: "Na curva perigosa dos cinquenta derrapei neste amor. Que dor! (?)”.

Abdias é narrado em percurso de meandro. O leitor é introduzido no fluxo de pensamento do herói, com ele tateia no avanço incerto. A história nada tem de linear, a reformulação é uma constante. Cyro dos Anjos maneja com maestria sua "omnisciência": a trama, de antemão conhecida pelo autor - é claro, recompõem-se continuamente a nossos olhos, como que ao acaso dos humores do Professor. Gabriela (a derrapagem na curva), de arrogante passa a generosa, Carlota (a esposa) vai de empecilho a santa, viagens estas que nos dão acesso à subjetividade do personagem. O que importa não é tanto o enredo, mas sua marca sobre Abdias, foco da narração.

O romance é introspectivo, relato e comentário da trama ligam-se de maneira indissolúvel. Abdias mistura passado e presente, imaginação e realidade. Curvado sobre sua vida, escreve diário; a seguir, desdobra-se, comentando o autor e seu diário; este, muito comprometedor, chega às mãos de Carlota e conclui seu trajeto de objetivação. A criatura escapa ao criador, para feri-lo a fundo em seu destino; ferimento que, por sua vez, é registrado em diário. Incapaz da vida refletida, assim como da narração linear, multiplica-se o Professor em planos de vida diversos, todos mutuamente referidos (e não perde, entretanto, a noção de que "a análise é, por certo, uma força do demônio").

Dos poucos momentos de ação simples, é a morte de Carlota, a esposa no fundo sempre querida. O contraste é belíssimo. À rápida descrição, acúmulo dos fatos, segue-se o mergulho no passado, e a verificação de que a morte é presente iniludível: "Não vi meu pai morrer, e era ainda pequeno quando perdi minha mãe. E minha mãe finou-se lentamente, após longa enfermidade. Jamais conhecera eu, assim, a presença repentina da morte, quando, em instantes, vemos apagar-se um olhar, uma expressão querida, que supúnhamos durariam sempre enquanto vivêssemos, acompanhando-nos solidariamente nessa misteriosa caminhada cujo termo, embora o saibamos fatal, nosso espírito se esquiva a conceber".

No plano sintático, é de se notar a relação entre Abdias e a estrutura da frase. A ligação desta última à trama, ainda que existente, é menos acentuada. A figura do Professor, é nítido, reflete-se em seu estilo. Afirmações, só as há cuidadosas. Tudo é 
dito com ressalvas, com restrições, dúvidas, entre vírgulas. Anti-retórico por excelência, o discurso vincula-se a espaço e tempo, na preocupação de retratar o mundo menor de seu pseudo-autor.

Quanto ao paralelismo de estilo e trama: A partir da reconciliação de Abdias e Carlota, principalmente após a morte desta, toma a frase um andamento mais largo. A nova atmosfera não se deve, apenas, às palavras novas (a morte pede outros termos, é claro); trata-se, isso sim, de um contraste rítmico face à narrativa anterior. A vírgula frequente, a guinada súbita do pensamento, o termo desusado, são todos instrumentos do pé-atrás, da auto-ironia que frente à morte se dilui. $\mathrm{O}$ texto fica como que apaziguado.

A multiplicidade dos planos de observação correspondem tempos diversos de narração. Basicamente, pode-se falar nos velhos tempos da mocidade e infância rural, e no tempo anterior à história relatada. De importância menor é o tempo que preside a elaboração do diário, cujo critério, como vimos no começo do artigo, é o da conveniência didática. A complexidade da narração provém, ao menos parcialmente, da interpenetração dos três. Não são raros os exemplos em que o presente deve sua inteligência ao passado, que emerge. Da conjugação dos tempos, de sua superposição, nasce o sentido da ação, nem pura resposta ao estímulo imediato, nem mergulho em labirinto sem volta. É à luz das passadas e juvenis aspirações sociais de Abdias que se explica sua desenxabida emoção, experimentada ao apertar a campainha da casa de sua aluna Gabriela, flor de um bem cuidado jardim burguês. "Enquanto apertava o botão elétrico da campainha, aguardando, no vestíbulo, que me viessem introduzir, tive a impressão de que a vida ia saldar comigo velhas dívidas e dar-me, de um momento para outro, o que até ali persistira em me negar".

Noutra parte, a propósito de $O$ Amanuense Belmiro, ficou dito que seria possível verificar a maior presença do tempo na fase ascensional do livro; isto pela simples contagem das locuções temporais. Ora: em Abdias são raras, na primeira parte e iniciando tópico, as orações que não contenham advérbios de tempo. Faria pouco sentido, entretanto, dizer que nesta fase o tempo está mais presente que noutras. Exemplo de que não basta saber contar.

A explicação poderia ser a seguinte: para Belmiro há uma separação clara entre o tempo da paixão e o antitempo do marasmo, do cotidiano. O tempo existe 
(consequentemente as locuções que o indicam), quando acontece história; e apaga-se quando os dias se tornam iguais. O tempo para Belmiro é a vida excepcional, e sua "presença quantitativa" liga-se diretamente à presença da paixão. Abdias, entretanto, militante das letras e das pesquisas sociais, da paternidade e do matrimônio, tem visão mais rica e complexa. Para o Professor existem dois tempos, entre os quais se debate: um, heroico, do amor pela impossível e demasiado jovem Gabriela; outro, sólido, tempo de vida menor porém profícua, junto à mulher e aos moleques. O que para Belmiro seria estagnação, para Abdias permanece como tempo. Verdade que não serve para os grandes amantes; serve, porém, tempo-formiga que é, à realização de pequenos trabalhos, como ter filhos ou dissertar sobre as Cartas Chilenas. Mais amplo, neste ponto, o Professor que o Amanuense.

Também o tempo do mundo exterior, inclusivo, no qual está inserto o livro, comparece. É a guerra mundial que "coincide" com a viuvez solitária de Abdias, e que somente é lembrada a propósito do discurso político de um amigo. Sintomática, no caso, esta aparição tão casual: Cyro dos Anjos não tem por objetivo o tempo do mundo, mas antes um tempo de ficar velho. Abdias, de quem Carlota diz estar na idade crítica, é forçado a reconhecer impossível seu diálogo com a outra geração. "Achava-me diante dessa essência volátil, desse momento dos seres que se chama mocidade, e Gabriela se integrara na luz matinal". Pouco depois, a aceitação explícita: "Há o tempo de amar, devaneando, e há o de cuidar, com prudência, nos encargos da maturidade. Há o tempo de ser jovem, o de ser homem, e o de ser velho". "Pode esse amor aquecer ainda o meu coração, mas seu reaparecimento há de ser ilusório como a existência meramente óptica de estrelas que já se extinguiram e que todavia continuam a ser vistas, porque sua luz ainda viaja nos espaços celestes".

Ao fim da melancólica aventura, morta Carlota, o balanço: "A sede das coisas novas leva-nos a desconhecer nosso próprio bem. Fugindo ao que me parecia medíocre, perdi-me num mundo de aparências enganosas". À diferença de Belmiro, porém, Abdias tem forças para a decisão, que é de moralista. "Não nos abismos, mas no altiplano da consciência é que há de fazer-se a devassa final. Que podemos contra esses abismos? Evitá-los e repeli-los, mas nunca, extingui-los”.

\footnotetext{
* Publicado originalmente no Suplemento Literário d'O Estado de S. Paulo, 31. jan. 1959, p. 39.
} 


\section{Relato (1961)*}

\section{POR ROBERTO SCHWARZ}

Estas coisas sempre deixam marca; no caso, parece que não pequena. $\mathrm{O}$ meu nome é Frederico. Seria indiscreto dar conta minuciosa do acontecido, o que posso dizer é que suscitou reflexão. Volto a me apresentar: não sou homem de carne e osso, pelo contrário até, sou apenas uma personagem literária. Não obstante, de uns tempos para cá passei à categoria dos seres vivos, quer dizer, atuantes. Ao leitor pode esta afirmação parecer ousada, mas nada contém de anormal. Pouco tempo após minha gênese literária, GP, meu autor, percebeu que sou a biografia de suas possibilidades mais simpáticas e interessantes. Além disto, considere-se que o público leitor me acolheu muito bem. Tomei, como se há de estar percebendo, uma certa autonomia em face de GP; adquiri a autoridade dos que fazem sucesso. Não quero ser convencido, mas para mim é certo que meu autor me vem copiando.

A aventura que vou semi-relatar é a primeira que posso chamar de propriamente minha. Explico melhor: é a primeira vez em que a figura decisiva fui eu, ainda que encarnado em GP. De outro ângulo, pode-se dizer que fui visto como boa perspectiva estratégica, um bom ponto de partida para a aventura. Em parêntese, entretanto, acrescento que minha figura literária é de quem tem duas mãos esquerdas, um péssimo aventureiro. Por que escolher-me, então, para estampa? Ou não se tratou exatamente de escolha - terá sido uma necessidade?

É muito difícil aflorar certos problemas ou relatá-los; na esfera da intimidade minúcia é quase igual a indiscrição. Não tenho, além do mais, confiança em meu A. Verdade que venho conseguindo ditar-lhe minhas normas porém não sei dizer quanto isto há de durar. Apesar de eu ser parte de GP, criação sua por assim dizer, sou muito diferente dele. Frederico, i.e. eu, é uma personagem coerente, ainda que complexa. Seu arcabouço psicológico é nítido, bem ao contrário dos mecanismos de seu A., que são ininteligíveis. A rigor só posso prever o comportamento de GP em duas situações: uma, quando me copia; outra, quando (muito simplificadamente) imita RS, amigo que admira. Em geral, de meu autor só posso dizer que é uma personagem desordenada. 
Como o leitor está percebendo, tenho pudor de contar o que realmente se passou. Apesar do que disse, estou consciente de que dependo de GP; não fosse ele emprestar-me a mão, nunca poderia escrever para os que me leem. Isto quer dizer que meu A. sabe o que penso dele, ou melhor, sabe o que ele pensa de si mesmo em certos momentos. O que me faz autônomo é não ser eu uma simples ideia, mas um fato em letra de forma, e mais, um fato que gera expectativas.

A dificuldade que experimento no início deste relato GP a experimentou, a expressão é figurada, ao vestir-me para sua aventura. Não é cômodo tornar-se inteligível. Posso adiantar que se tratou, no caso, de uma aventura amorosa.

Como personagem tenho feição bastante estranha. Falo muito, porém o que digo não importa. Mais exatamente, só digo o que não importa; o essencial, o cerne, está no que ficou sem ser dito. A título de exemplo, este conto. A aventura cuja narração venho protelando é espantosamente simples. Nem mereceria o nome de aventura, não fosse o que ela faz vislumbrar, ou antes, o que ela esconde.

Em situações difíceis (toda aventura amorosa as tem), o melhor é passar à margem, silencioso, resolvê-las por simples presença física, proximidade dos corpos. Nomear ou explicar seriam modos de fazer-se prisioneiro. A discussão envolveria campos tão diversos, tão obscuros e, entretanto, constitutivos, envolveria colocações pessoais que não requerem defesa mas guarida - a mão de GP, meu autor, escreve obediente o que lhe dito. É inevitável que saiba dessas minhas reflexões, já as conhece de há muito. Nada são, aliás, de notável - o descrédito de argumento e fala anda no ar - mas iluminam sua atitude ao aceitar uma aventura dentro de minha perspectiva: desejava uma ligação que, muda e por isso mesmo, fosse estreita; não sentimental, uma tentativa de redimir o açúcar de nossos antecessores. Previno o leitor contra uma falsa interpretação: conhecemos Freud, é claro, e as virtualidades da posição horizontal. Mesmo esta, porém, perdeu sua aura de solução entre todas. Dentre os diversos açúcares que herdamos este é dos mais insidiosos; um romantismo às avessas a suposição de que um lençol branco e um leito partilhado tudo clareiam.

Concedo que me precipitei. Estou apresentando reflexões que deveriam vir ao fim, como corolário da aventura que sequer contei. Poderia agora continuar, sem voltar atrás, pois a aventura em si, como já disse, não tem nenhuma importância; e se é que ia contá-la, era com fito didático, para que melhor me compreendessem. Mais 
importante que voltar, entretanto, é refletir sobre a causa da precipitação, do hiato involuntário que introduzi neste relato. Se consideramos que GP nunca deixaria de narrar sua aventura, pois esta lhe foi importante, veremos que desimportante ela só foi para mim, a quem nada de novo apresentou. O leitor atento nesta altura percebe que falo de Frederico (que sou eu) e GP como de duas figuras diversas, o que significa já não sermos unos. É exatamente o que o leitor está pensando: houve uma re-cisão, vinda na crista desse autoexame. Não partiu de mim, é evidente, que só tinha a ganhar com a condição de vivo, e que, ao fim de contas, não posso tomar atitudes por vontade própria. A motivação foi simples: GP não suportou a existência lógica que eu lhe impunha.

Voltando ao pouco interesse da aventura: ela nada de novo me apresentou. Correu dentro de meus padrões. Questões sérias resolviam-se por simples proximidade física; o contato corpóreo diz muito, tem memória curta, é um juiz melhor. Falávamos bastante. Coisas inteligentes, que não se referiam precisamente a coisa alguma. Carapuça do indizível; maneira, como outra qualquer, de resguardar a liberdade. Repito que não quis colocar a solução na cama. Condormir é bom mas não é tudo. Talvez fosse melhor dizer, em vez de "proximidade física", proximidade só. “As questões mais sérias resolviam-se pela simples proximidade, que é um juiz melhor". Meus padrões, é claro, não são desconhecidos de GP, pois foi ele que os inventou em mim. A diferença, entretanto, é grande. De imaginar uma personagem até comportar-se como ela vai um pedaço. A importância do acontecido, para meu autor, está em ter ele vivido por algum tempo o que imaginou. Num dado momento, contudo (ápice da aventura), GP não suportou as dificuldades de minha posição, e abdicou.

Uma situação fica ultrapassada, abre-se ao balanço. Não há nenhum mérito nesse exame, nem na simplicidade que permite seccionar um cadáver ainda vivo. Não há também crueldade, pois não estou alheio. A prévia autópsia que faço não se refere apenas à aventura de GP; com ela morro também. A insistência, aliás, com que o nome Gaspar aparece no pensamento de meu A. talvez seja indício de que eu esteja em vias de ser uma personagem superada.

GP prossegue, por enquanto, em sua ligação com Maria; eu estou ausente. O que de Frederico existe em meu autor está ausente, ou melhor, como expectador. É fácil ver como GP perde terreno e sentido. A decomposição é lenta mas segura - não 
fosse eu quem enformou esta ligação! Exemplo de quanto minha ausência é letal tive ontem à noite. Fomos ao teatro (permitem-me ficar ao lado, comentando), ver uma peça em que o passado tinha razão. $O$ autor, moço, usava de sua inteligência para mostrar as coisas que não podemos usar. Ao fim da peça observamos quanto é nossa esta lucidez que se sabe inútil, esse arabesco em torno da substância intocada. Pois bem: uma tal observação, quando GP ainda se prendia a mim, nos áureos tempos, seria feita e debatida em tom estritamente impessoal, mas se sabendo de quem partira - já que seria insuportável dar-se por achado em mecanismos tão evidentes; mesmo porque as coisas são mais complexas. Agora (ontem), GP chegou a apelar para exemplificações pessoais. Se eu tivesse corpo, me torceria de vergonha ante a chantagem de usar a própria biografia. É como ir a um concerto e prender-se ao rosto do pianista. A mim, Frederico, só posso dizer que repugna isso de sempre procurar a fonte obscura de nossos atos - não há recém-nascido que não seja vermelho e lambuzado. O abismo torna-se definitivo: GP tenta explicar as negativas de Maria. Já não suporta nada que seja opaco, ao que perde todo o compacto; é como se eu não tivesse existido.

A cisão, forma de derrota, é inevitável. Faria pouco sentido prever seus caminhos. Será simples, pois algum papel nesta história toda ainda tenho; ao menos exteriormente; e no caso o hábito fará o monge.

Dificuldade de narrar o passado não há mais nenhuma. Como personagem que sou de histórias completas e bem estruturadas, não há lugar em mim para o imponderável e, principalmente, para a desordem. Saio airoso como entrei. Maria criou desordem foi em GP, que não se refará tão logo, mesmo guardando a lucidez necessária para escrever estas linhas. Um engano, aliás, confundir lucidez com superação. Se curiosidade permanece, é de saber como será Gaspar.

* Publicado originalmente no Suplemento Literário d'O Estado de S. Paulo, 8 abr. 1961, p. 37. 


\section{Textos do autor por ordem cronológica (1958-1972)}

1958

“Dois sonetos”. In: Suplemento Literário d'O Estado de S. Paulo, 18 out. 1958, p. 11. “Linguagem de uma novela". In: idem, 20 dez. 1958, p. 33.

1959

“Tempo de ficar velho". In: idem, 31. jan. 1959, p. 39.

“No centro: Mário Chamie”. In: idem, 18 abr. 1959, p. 35.

“Entre ser e parecer”. In: idem, 19 set. 1959, p. 39.

“Anchieta: teatro didático”. In: idem, 03 out. 1959, p. 14.

Pássaro na gaveta. São Paulo: Massao Ohno, 1959 (poesia).

1960

“Grande-Sertão e Dr. Faustus”. In: Suplemento Literário, 9 abr. 1960, p. 7.

“Grande-Sertão e Dr. Faustus" (Parte II). In: idem, 23 abr. 1960, p. 9.

“Grande-Sertão em curso”. In: idem, 30 abr. 1960, p. 39.

“O Atheneu e o naturalismo”. In: idem, 10 set. 1960, p. 40.

1961

“A estrutura de Chanaan”. In: idem, 14 jan. 1961, p. 42.

“Relato". In: idem, 8 abr. 1961, p. 37.

“O psicologismo na poética de Mário de Andrade”. In: idem, 20 mai. 1961, p. 44.

“O psicologismo na poética de Mário de Andrade” (Parte II), 27 mai. 1961, p. 42. 
"Uma barata é uma barata é uma barata". In: A Sereia e o desconfiado. Rio de Janeiro: Civilização Brasileira, 1965, pp. 42-55.

“Para a fisionomia de Os Demônios". In: idem, pp. 56-63.

“O mano capeta do liberalismo (O Sósia)”. In: idem, pp. 64-79.

1962

“Existencialismo e romance histórico (Malraux)”. In: idem, pp. 80-91.

“Emília Galotti e o nascimento do Realismo". In: idem, pp. 92-114.

1963

“A Letra Escarlata e o Puritanismo". In: idem, pp. 115-31.

"Retrato de uma Senhora (o método de Henry James). In: idem, pp. 132-46.

“Dinheiro, memória, beleza (O Pai Goriot)”. In: idem, pp. 147-67.

1964

“8 1² de Fellini”. In: Civilização Brasileira. Rio de Janeiro, 1965, n. 1, pp. 197-211.

“Sobre O amanuense Belmiro". In: idem, 1966, n. 8, pp. 161-70.

1966

“A tribulação do pai de família”. In: Suplemento Literário, 12 mar. 1966, p. 46.

“Dreifuss \& Cefalu Ltda.”. In: Idem, 07 mai. 1966, p. 37.

“O Cinema e os Fuzis”. In: Civilização Brasileira. Rio de Janeiro, 1967, n. 9/10, pp. 217-22 (trad. sueca: “Filmen och gevären”. In: ord \& bild. Estocolmo, 1968, n. 7). 
“Sobre o raciocínio político de Oliveiros S. Ferreira”. In: Teoria e Prática. São Paulo, 1967, n. 1, pp. 98-112.

“Nota sobre vanguarda e conformismo". In: idem, 1968, n. 2, pp. 127-32.

“9 experimentos”. In: Revista Mirantes das Artes, etc. São Paulo, mar.-abr. 1967, n. 2, pp. 28-9 (poesia).

1968

"Um folheto de iniciação política - Didatismo e Literatura”. In: idem, 1968, n. 3, pp. 147-57 (trad. sueca: “Didaktik och literatura”. In: Zenit. Estocolmo, 1968, n. 5).

1969

"A Lata de lixo da história (Farsa)". In: Almanaque. São Paulo: Brasiliense, 1977, n. 4, pp. 60-79 (teatro).

1970

“Remarques sur la culture et la politique au Brésil, 1964-1969”. In: Les Temps Modernes. Paris, jul. 1970, n. 288, pp. 37-73 (edição brasileira: “Cultura e política, 1964-1969". In: O pai de família e outros estudos. Rio de Janeiro: Paz e Terra, 1978, pp. 61-92; trad. cubana: “Cultura y política en Brasil, 1964-1969”. In: Casa de las Americas. Havana, jul-ago. de 1970; trad. alemã: "Kultur und Politik im zeitgenöessischen Brasilien”, transmissão do Hessischer Rundfunk, 13 e 14 abr. 1971; trad. italiana: “Cultura e politica in Brasile”. Angelus Novus. Veneza, 1972, n. 23).

“19 princípios para a crítica literária”. In: Almanaque. São Paulo: Brasiliense, 1976, n. 2 , p. 5. 
"Malcomparando". In: Tavares, Zulmira Ribeiro. Termos de comparação. São Paulo: Perspectiva, 1974, pp. 9-10 (prefácio).

"Utopia”. In: O pai de família e outros estudos, op. cit., pp. 97-8.

"Dépendance nationale, déplacement d'idéologies, littérature: sur la culture brésilienne au XIX ème siècle”. In: L'Homme et la Société. Paris, 1972, n. 26, pp. 99110 (edição brasileira: “As ideias fora do lugar”. In: Estudos Cebrap. São Paulo, jan. 1973, n. 3, pp. 149-61; trad. cubana: "Dependencia nacional, desplazamiento de ideologias, literatura". In: Casa de las Americas, nov-dez. de 1973). 


\section{REFERÊNCIAS BIBLIOGRÁFICAS}

Obras do autor

SCHWARZ, Roberto. Martinha versus Lucrécia. São Paulo: Cia. das Letras, 2012. . Sequências brasileiras. São Paulo: Companhia das Letras, 1999. . Duas meninas. São Paulo: Companhia das Letras, 1997. . Um mestre na periferia do capitalismo. SP: Duas Cidades/Ed. 34, 2000. . Que horas são? São Paulo: Companhia das Letras, 1989. . Ao vencedor as batatas: forma literária e processo social nos inícios do romance brasileiro. São Paulo: Duas Cidades/Ed. 34, 2000.

. O pai de família e outros estudos. São Paulo: Companhia das Letras, 2008. . A Sereia e o desconfiado. São Paulo: Paz e Terra, 1981.

. A lata de lixo da história: chanchada política. São Paulo: Companhia das Letras, 2014 (teatro). . Corações veteranos. Rio de Janeiro: Coleção Frenesi, 1974 (poesia). . Pássaro na gaveta. São Paulo: Massao Ohno, 1959 (poesia).

. "Percurso". In: Memorial Unicamp (apresentado por ocasião do concurso para professor titular no Instituto de Estudos da Linguagem). São Paulo: Arquivo Central - AC/SIARQ, 1990, pp. 1-5 (datilografado).

Entrevistas e debates com o autor

- “As ideias fora do lugar" (entrevista a Gilberto F. Vasconcellos e Leo Wolfgang Maar). In: Movimento. São Paulo, n. 56, 26 jul. 1976, pp. 16-7. . "Entrevista com Gildo Marçal Brandão e O. C. Louzada Filho". In: Encontros com a Civilização Brasileira, Rio de Janeiro, n. 15, set. 1979, pp. 97-112. . "Mesa-redonda". In: Bosi, Alfredo et alii. Machado de Assis - antologia e estudos. São Paulo: Ática, 1982, pp. 310-43.

. "Roberto Schwarz põe as coisas no lugar (entrevista a Augusto Massi). In: Folha de S. Paulo, 8 nov. 1987, p. 57.

. "Dois mestres na periferia do capitalismo" (entrevista a Teixeira Coelho). In: O Estado de S. Paulo, 16 ago. 1990, p. 4. 
. "Roberto Schwarz: um intelectual com as ideias no lugar" (entrevista a Humberto Werneck). In: Jornal do Brasil. Rio de Janeiro, 29 dez. 1990, pp. 6-10.

. "Machado de Assis: Um Debate - conversa com Roberto Schwarz" (debate com Davi Arrigucci Jr., Francisco de Oliveira, José Antonio Pasta Jr., José Arthur Giannotti, Luiz Felipe de Alencastro e Rodrigo Naves). In: Novos Estudos Cebrap, São Paulo, n. 29, mar. 1991, pp. 59-84.

. "Do lado da viravolta". In: Haddad, Fernando (org.). Desorganizando o consenso: 9 entrevistas com intelectuais dissidentes (entrevista a Fernando Haddad e Maria Rita Kehl). Petrópolis, RJ: Vozes, 1998, pp. 15-26.

. "A dialética envenenada de Roberto Schwarz" (entrevista a Fernando de Barros e Silva). In: Folha de S. Paulo, 01 jun. 1997, pp. 64-8.

. "O Brasil que acabou" (entrevista a Fernando de Barros e Silva). In: Folha de S. Paulo, 07 ago. 1999, p. 10.

. “Antonio Risério e Roberto Schwarz". In: Outros 500: Novas conversas sobre o jeito do Brasil. Porto Alegre, Prefeitura Municipal de Porto Alegre, Secretaria Municipal da Cultura, 2000, pp. 174-210.

. "Tira-dúvidas com Roberto Schwarz" (entrevista a Afonso Fávero, Aírton

Paschoa, Francisco Mariutti e Marcos Falleiros). In: Novos Estudos Cebrap, São Paulo, n. 58, nov. 2000, pp. 53-71.

. "Entrevista com Roberto Schwarz" (a Eva L. Corredor). In: Literatura e Sociedade, São Paulo, DTLLC-FFLCH-USP, n. 6, 2001-2002, pp. 14-37.

- "Desapareceu a perspectiva de um progresso que torne o país decente" (entrevista a Marcos Augusto Gonçalves e Rafael Cariello). In: Folha de S. Paulo, 11 ago. 2007, pp. 8-9.

- "Ao vencedor as batatas 30 anos: crítica da cultura e processo social. Entrevista com Roberto Schwarz" (entrevista a Lilia Schwarcz e André Botelho). In: Revista Brasileira de Ciências Sociais, São Paulo, vol. 23, n. 67, jun. 2008, pp. 14760.

- "Roberto Schwarz" (entrevista a Ismail Xavier, Ângela Alonso, Flávio Moura e Henri Gervaiseau). In: Moura, Flávio; Montero, Paula (orgs.). Retrato de grupo: 40 anos do Cebrap. São Paulo: Cosac Naify, 2009, pp. 227-45.

. "A Lata de Lixo da História: Chanchada Politica. Conversa com Roberto Schwarz" (com a participação de Sérgio de Carvalho). In: Revista Terceira Margem, Rio de Janeiro, vol. 18, n. 30, jul.-dez. 2014, pp. 227-43. 
Estudos sobre o autor

ALAMBERT, Francisco. "Lugar da dialética, dialética do lugar. Três notas sobre filiações, fidelidades e afinidades na formação intelectual de Roberto Schwarz". In: Musse, Ricardo; Loureiro, Isabel (orgs.). Capítulos do marxismo ocidental. São Paulo: Editora Unesp, 1998, pp. 229-47.

ARANTES, Otília. "Arquitetura Nova antigamente: o que fazer? Conversando com um modernista recalcitrante". In: Revista Trans/Form/Ação. São Paulo, 1995, n. 18, pp. 15-22.

ARANTES, Paulo Eduardo. Sentimento da dialética na experiência intelectual brasileira: dialética e dualidade segundo Antonio Candido e Roberto Schwarz. Rio de Janeiro: Paz e Terra, 1992.

BOSI, Alfredo. "A escravidão entre dois liberalismos". In: Dialética da colonização. São Paulo: Companhia das Letras, 1992, pp. 194-245.

BRITO, Antônio Carlos de (Cacaso). “Uma análise concreta de uma situação concreta': Roberto Schwarz x Machado de Assis”. In: Movimento, São Paulo, 3 out. 1977, p. 17.

CARVALHO FRANCO, Maria Sylvia de. "As ideias estão no lugar". In: Cadernos de Debate. São Paulo: Brasiliense, 1976, n. 1, pp. 61-4.

CARVALHO, Sérgio de. "Questões sobre a atualidade de Brecht”. In: Revista Sala Preta. São Paulo, 2006, v. 6, pp. 167-73.

CEVASCO, Maria Elisa. "The São Paulo fraction: lineaments of a cultural formation". In: Mediations. Chicago, 2014, v. 28, pp. 75-95.

. "Modernização à Brasileira". In: Revista do Instituto de Estudos Brasileiros. São Paulo, dez. 2014, n. 59, pp. 191-212.

CEVASCO, Maria Elisa; OHATA, Milton (orgs.). Um crítico na periferia do capitalismo: reflexões sobre a obra de Roberto Schwarz. SP: Cia. das Letras, 2007.

COSTA LIMA, Luiz. "Sobre a questão da mímesis. Carta a Roberto Schwarz”. In: Novos Estudos Cebrap, n. 33, São Paulo, 1992, pp. 171-2.

. “Schwarz e a crítica nacional". In: Suplemento Literário d'O Estado de S.

Paulo, 11 dez. 1965, p. 35.

EULALIO, Alexandre. "Pai de família, mas desconfiado". In: Livro involuntário. Rio de Janeiro: Ed. UFRJ, 1993, pp. 313-17.

GLEDSON, John. "Roberto Schwarz: Um mestre na periferia do capitalismo". In: 
Por um novo Machado de Assis. São Paulo: Cia. das Letras, 2006, pp. 236-78.

GONÇALVES, Anderson; OTSUKA, Edu Teruki; RABELLO, Ivone Daré. "O retratista e os intelectuais às voltas com 1964". In: Revista do Instituto de Estudos Brasileiros, n. 57, São Paulo, dez. 2013, pp. 327-48.

LAFETÁ, João Luiz. "Batatas e desejos". In: A dimensão da noite e outros ensaios. São Paulo: Duas Cidades/Ed. 34, 2004, pp. 103-13.

LARSEN, Neil. "Roberto Schwarz: A Quiet (Brazilian) Revolution in Critical Theory". In: Determinations - Essays on Theory, Narrative and Nation in the Americas. London: Verso, 2001, pp. 75-82.

- "Hegemony or Ideology? Observations on Brazilian Fascism and the Cultural Criticism of Roberto Schwarz". In: Reading north by south: on Latin American literature, culture, and politics. Minneapolis: University of Minnesota Press, 1995, pp. 93-9.

LEBRUN, Gerárd. “Algumas confusões, num severo ataque à intelectualidade”. In: Discurso (USP), 1980, n. 12, pp. 145-52.

MERQUIOR, José Guilherme. “A crítica de Roberto Schwarz". In: Suplemento Literário d'O Estado de S. Paulo, 5 fev. 1966, p. 40.

MOTA, Carlos Guilherme. "Vanguarda e conformismo, segundo Roberto Schwarz". In: Ideologia da cultura brasileira (1933-1974). São Paulo: Ática, 1994, pp. 245-9.

MOURA, Flávio Rosa de. "Um crítico no redemoinho". In: Revista Tempo Social (USP). São Paulo, nov. 2011, vol. 23, n. 2, pp. 71-99.

OTSUKA, Edu Teruki. "Sequências brasileiras, ruptura mundial”. In: Eutomia, v. 1, n. 11, Recife: UFPE, jan.-jun. 2013, pp. 199-213.

. “Cultura e política, ainda". In: Nitschack, Horst; García, Mónica González (orgs.). Diálogos Sur-Sur: Década de 1960 y transformaciones culturales en Brasil y las Americas. Homenaje a Roberto Schwarz. Chile, 2016 (no prelo).

PRADO JÚNIOR, Bento. “A sereia desmistificada”. In: Alguns ensaios: filosofia, literatura, psicanálise. São Paulo: Paz e Terra, 2000, pp. 201-17.

RICUPERO, Bernardo. "O lugar das ideias: Roberto Schwarz e seus críticos”. In: Sociologia \& Antropologia, Rio de Janeiro, 2013, v. 3, pp. 525-56.

. "Da formação à forma. Ainda as 'ideias fora do lugar."” In: Lua Nova, São Paulo, 2008, v. 73, pp. 59-69.

ROUANET, Sérgio Paulo. "Contribuição para a dialética da volubilidade". In: Revista USP, n. 9, 1991, pp. 175-94. 
SADER, Emir. "Nós que amávamos tanto o capital - fragmentos para a história de uma geração”. In: Sociologias (UFRGS). Porto Alegre, 2005, n. 14, pp. 150-77.

SAFATLE, Vladimir. "A dialética do romance nacional: retorno ao debate Roberto Schwarz/Bento Prado Jr.". In: Dar corpo ao impossível: o sentido da dialética a partir de Theodor Adorno. Belo Horizonte: Autêntica Editora, 2019, pp. 273-97.

SANTIAGO, Silviano. "Para além da história social”. In: Riedel, Dirce Côrtes (org.). Narrativa: ficção e história. Rio de Janeiro: Imago, 1988, pp. 241-56.

SCHNAIDERMAN, Boris. "A tímida sereia e o crítico desconfiado". In: Suplemento Literário d'O Estado de S. Paulo, 30 jul. 1966, p. 33.

SÜSSEKIND, Flora. "Ou não? - notas sobre a crítica de Davi Arrigucci e Roberto Schwarz”. In: Papéis colados. Rio de Janeiro: Ed. UFRJ, 1993, pp. 35-51.

VASCONCELOS, Sandra Guardini Teixeira. "Roberto Schwarz, um leitor radical de Machado". In: Oliveira, Paulo Ramos de; Franco, Renato (orgs.). Políticas e poéticas do inconformismo. Rio de Janeiro: Azougue, 2014, pp. 63-74.

WAIZBORT, Leopoldo. "Desiguais porém combinados". In: A passagem do três ao um. São Paulo: Cosac Naify, 2007, pp. 11-84.

. "Roberto Schwarz: entre forma literária e processo social". In: Botelho,

André; Schwarcz, Lilia M. (orgs.). Um enigma chamado Brasil. São Paulo: Companhia das Letras, 2009, pp. 406-17.

$\underline{\text { Bibliografia geral }}$

ADORNO, Theodor; HORKHEIMER, Max. Dialética do Esclarecimento. Rio de Janeiro: Jorge Zahar, 1985.

ADORNO, Theodor. Notas de literatura I. São Paulo: Duas Cidades; Ed. 34, 2003. . Teoria estética. Lisboa: Edições 70, 2008.

. Minima moralia: reflexões a partir da vida lesada. Rio de Janeiro:

Azougue, 2008.

- "Crítica cultural e sociedade". In: Prismas: crítica cultural e sociedade.

São Paulo: Ática, 1998, pp. 7-26.

. “Schoenberg e o Progresso". In: Filosofia da nova música. São Paulo:

Perspectiva, 1974, pp. 33-107.

ALMEIDA, Maria Hermínia Brandão Tavares de; WEIS, Luiz. “Carro-zero e pau-dearara: o cotidiano da oposição de classe média ao regime militar”. In: Schwarcz, Lilia 
K. Moritz (org.). História da vida privada no Brasil: contrastes da intimidade contemporânea. São Paulo: Companhia das Letras, 2000, pp. 319-409.

Anais do II Congresso Brasileiro de Crítica e História Literária (24-30 jul. 1961). Assis, SP: Faculdade de Filosofia, Ciências e Letras de Assis, 1963 (particularmente: os apartes de Antonio Candido, às pp. 120-1 e 150-2; e de Roberto Schwarz, às pp. 398-400).

ANDERSON, Benedict. Comunidades imaginadas: reflexões sobre a origem e a difusão do nacionalismo. São Paulo: Companhia das Letras, 2008.

ANDERSON, Perry. Considerações sobre o marxismo ocidental / Nas trilhas do materialismo histórico. São Paulo: Boitempo, 2004.

. "Modernidade e revolução". In: Novos Estudos - Cebrap. São Paulo, fev. 1986, n. 14, pp. 2-15.

ARANTES, Paulo Eduardo. O novo tempo do mundo: e outros estudos sobre a era da emergência. São Paulo: Boitempo, 2014.

. O fio da meada. Rio de Janeiro: Paz e Terra, 1996.

- Um departamento francês de Ultramar: estudos sobre a formação da cultura filosófica uspiana. Rio de Janeiro: Paz e Terra, 1994.

. Hegel: a ordem do tempo. São Paulo: Hucitec/Polis, 2000.

- "Providências de um crítico literário na periferia do capitalismo". In:

Sentido da formação: três estudos sobre Antonio Candido, Gilda de Mello e Souza e Lúcio Costa. Rio de Janeiro: Paz e Terra, 1997, pp. 7-66.

. "Conversa com um filósofo zero à esquerda". Zero à esquerda. São Paulo:

Conrad, 2014, pp. 257-98.

AUERBACH, Erich. Mimesis: a representação da realidade na literatura ocidental.

São Paulo: Perspectiva, 2013.

BADER, Wolfgang (org.). Brecht no Brasil - Experiências e influências. Rio de Janeiro/São Paulo: Paz e Terra, 1987.

BENJAMIN, Walter. Ensaios sobre Brecht. São Paulo: Boitempo, 2017.

. Magia e técnica. Arte e Política. (Obras escolhidas I). São Paulo: Brasiliense, 1993.

. Charles Baudelaire: um lírico no auge do capitalismo (Obras escolhidas

III). São Paulo: Brasiliense, 2010.

. Documentos de cultura, documentos de barbárie: escritos escolhidos. São

Paulo: Cultrix/Editora da Universidade de São Paulo, 1986. 
BRECHT, Bertolt. Estudos sobre teatro. Rio de Janeiro: Nova Fronteira, 2005.

BÜRGER, Peter. Teoria da vanguarda. São Paulo: Cosac Naify, 2008.

CANDIDO, Antonio. Formação da literatura brasileira. São Paulo/Rio de Janeiro: Ouro sobre Azul, 2009. . Brigada ligeira. Rio de Janeiro: Ouro sobre Azul, 2004. . O discurso e a cidade. Rio de Janeiro: Ouro sobre Azul, 2010. . Literatura e sociedade. Rio de Janeiro: Ouro sobre Azul, 2011. . "Literatura e subdesenvolvimento"; "A Revolução de 1930 e a cultura". In: A educação pela noite. Rio de Janeiro: Ouro sobre Azul, 2006, pp. 169-96; 219-40. . “A literatura brasileira em 1972”. In: Arte em revista. São Paulo, 1981, n. 1, pp. 20-6.

. “A organização do $2^{\circ}$ Congresso". In: Antunes, Benedito; Ferreira, Sandra. 50 anos depois: estudos literários no Brasil contemporâneo. São Paulo: Editora Unesp, 2014, pp. 215-8.

CARDOSO, Fernando Henrique. Capitalismo e escravidão no Brasil meridional. São Paulo: Difel, 1962. . Empresário industrial e desenvolvimento econômico no Brasil. São Paulo: Difel, 1964. ; FALETTO, Enzo. Dependência e desenvolvimento na América Latina. Rio de Janeiro: Zahar, 1970.

CARVALHO FRANCO, Maria Sylvia de. Homens livres na ordem escravocrata. São Paulo: Unesp, 1997.

COSTA, Iná Camargo. A hora do teatro épico no Brasil. Rio de Janeiro: Paz e Terra, 1996.

DARDOT, Pierre; LAVAL, Christian. A nova razão do mundo: ensaio sobre a sociedade neoliberal. São Paulo: Boitempo, 2016.

DREIFUSS, René. 1964: A conquista do Estado - Ação política, poder e golpe de classe. Petrópolis: Vozes, 1981.

FANON, Frantz. Os condenados da terra. Rio de Janeiro: Civilização Brasileira, 1979.

FERRO, Sérgio. “Arquitetura Nova”. In: Revista Teoria e Prática. São Paulo, 1967, n. 1, pp. 3-15.

FERNANDES, Florestan. A revolução burguesa no Brasil. Ensaio de interpretação sociológica. São Paulo: Globo, 2008. 
FERREIRA, Jorge (org.). O populismo e sua história: debate e crítica. Rio de Janeiro: Civilização Brasileira, 2001.

. O imaginário trabalhista: getulismo, PTB e cultura política popular (1945-1964). Rio de Janeiro: Civilização Brasileira, 2005.

FURTADO, Celso. Formação econômica do Brasil. São Paulo: Companhia das Letras, 2011.

. A pré-revolução brasileira. Rio de Janeiro: Fundo de Cultura, 1962.

. Subdesenvolvimento e estagnação na América Latina. Rio de Janeiro:

Civilização Brasileira, 1966.

GIANNOTTI, José Arthur. "Notas para uma análise metodológica de O Capital". In: Revista Brasiliense. São Paulo, Brasiliense, 1960, n. 29, pp. 60-72.

. “Contra Althusser". In: Exercícios de filosofia. Petrópolis, Rio de Janeiro: Vozes, 1980, pp. 85-102.

GORENDER, Jacob. Combate nas trevas. São Paulo: Ática, 1998.

GRANDIN, Greg. The Last Colonial Massacre: Latin America in the Cold War. Chicago: University of Chicago Press, 2004.

HARTOG, François. Regimes de historicidade: presentismo e experiências do tempo. Belo Horizonte: Autêntica, 2013.

HEGEL, Georg. Fenomenologia do espírito. Petrópolis, RJ: Vozes; Bragança Paulista: Editora Universitária São Francisco, 2012. . A Razão na História. Introdução à filosofia da história universal. Lisboa: Edições 70, 1995.

HOLANDA, Sérgio Buarque de. Raízes do Brasil. São Paulo: Companhia das Letras, 2015.

HOLlANDA, Heloísa Buarque de; Gonçalves, Marcos Augusto. Cultura e participação nos anos 1960. São Paulo: Brasiliense, 1986.

HOLLANDA, Heloísa Buarque de. Impressões de viagem (CPC, vanguarda e desbunde). São Paulo: Brasiliense, 1981.

IANNI, Octávio; SINGER, Paulo; COHN, Gabriel; WEFFORT, Francisco. Política e revolução social no Brasil. Rio de Janeiro: Civilização Brasileira, 1965.

IANNI, Octávio. O colapso do populismo no Brasil. Rio de Janeiro: Civilização Brasileira, 1975.

JAMESON, Fredric. O inconsciente político: a narrativa como ato socialmente simbólico. São Paulo: Ática, 1992. 
. "Periodizando os anos 60". In: Buarque de Hollanda, Heloísa (org.). PósModernismo e política. Rio de Janeiro: Rocco, 1992, pp. 81-126.

. "Rumo à crítica dialética". In: Marxismo e Forma: teorias dialéticas da literatura no século XX. São Paulo: Hucitec, 1985, pp. 250-315.

• “A lógica cultural do capitalismo tardio". In: Pós-modernismo: a lógica cultural do capitalismo tardio. São Paulo: Ática, 1996, pp. 27-79.

KOSELLECK, Reinhart. Futuro passado: contribuição à semântica dos tempos históricos. Rio de Janeiro: Contraponto/PUC-Rio, 2010.

LAÏDI, Zaki. A chegada do homem-presente ou da nova condição do tempo. Lisboa: Instituto Piaget, 2001.

LUKÁCS, Georg. A teoria do romance. São Paulo: Editora 34, 2000.

. O romance histórico. São Paulo: Boitempo, 2011.

. Arte e sociedade: escritos estéticos 1932-1967. Rio de Janeiro: Editora UFRJ, 2011.

. Ensaios sobre literatura. Rio de Janeiro: Civilização Brasileira, 1965.

. Marxismo e teoria da literatura. São Paulo: Expressão Popular, 2010.

. Realistas alemanes del siglo XIX. Barcelona: Grijalbo, 1970.

. História e consciência de classe: estudos sobre a dialética marxista. São Paulo: Martins Fontes, 2003.

. “Alegoria y símbolo". In: Estética. Barcelona/México, D.F.: Grijalbo, 1967, vol. 4, pp. 423-74.

. "Nota sobre o romance.” In: Georg Lukács: sociologia. São Paulo: Ática, 1981.

MARTINS FILHO, João Roberto. Movimento estudantil e ditadura militar, 19641968. Campinas: Papirus, 1987.

MARX, Karl; ENGELS, Friedrich. A ideologia alemã. São Paulo: Boitempo, 2007.

NOVAIS, Fernando. Portugal e Brasil na crise do Antigo Sistema Colonial (17771808). São Paulo: Hucitec, 1979.

OLIVEIRA, Francisco de. Crítica à razão dualista/O ornitorrinco. São Paulo: Boitempo, 2003.

. "O adeus do futuro ao país do futuro: uma biografia breve do Brasil". In:

Brasil: uma biografia não autorizada. São Paulo: Boitempo, 2018.

OTSUKA, Edu Teruki. Era no tempo do rei: atualidade das Memórias de um sargento de milícias. Cotia, SP: Ateliê Editorial, 2016. 
PASTA JR., José Antonio. Trabalho de Brecht: breve introdução ao estudo de uma classicidade contemporânea. São Paulo: Duas Cidades; Ed. 34, 2010.

. Formação supressiva: constantes estruturais do romance brasileiro. $282 \mathrm{f}$. Tese (Livre-Docência em Literatura Brasileira) - USP, 2011.

. "Brecht/Brasil/1997 (vinte anos depois)". In: Benjamin, Walter. Ensaios sobre Brecht. São Paulo: Boitempo, 2017, pp. 133-9.

- "Variação machadiana sobre o tema da formação". In: Tensões $e$ Passagens: filosofia e modernidade. Org. Daniel Tourinho Peres et al. São Paulo: Singular / Esfera Pública, 2008, pp. 255-63.

PÉCAUT, Daniel. Os intelectuais e a política no Brasil: entre o povo e a nação. São Paulo: Ática, 1990.

PRADO Jr., Caio. Formação do Brasil contemporâneo. São Paulo: Brasiliense, 1987. . A revolução brasileira. São Paulo: Brasiliense, 1966.

PRADO, Décio de Almeida. Exercício findo. São Paulo: Perspectiva, 1987.

REIS FILHO, Daniel Aarão. A revolução faltou ao encontro. São Paulo: Brasiliense, 1990.

RIDENTI, Marcelo. Em busca do povo brasileiro. Rio de Janeiro: Record, 2000.

. O fantasma da revolução brasileira. São Paulo: Unesp, 2010.

RODRIGUES, Lidiane Soares. A produção social do marxismo universitário em São Paulo: mestres, discípulos e 'um seminário' (1958-1978). 565 f. Tese (Doutorado em História Social) - USP, 2011.

ROSENFELD, Anatol. O mito e o herói no moderno teatro brasileiro. São Paulo: Perspectiva, 1996.

SALES GOMES, Paulo Emílio. Cinema: trajetória no subdesenvolvimento. Rio de Janeiro: Paz e Terra, 1996.

SANTOS, Maria Cecília Loschiavo dos (org.). Maria Antônia: uma rua na contramão. São Paulo: Nobel, 1988.

SARTRE, Jean-Paul. Questão de método. São Paulo: Difel, 1967.

SZONDI, Peter. Teoria do drama moderno (1880-1950). São Paulo: Cosac Naify, 2011.

TAUBES, Jacob. "Cultura e ideología”. In: Del culto a la cultura: elementos para una crítica de la razón histórica. Madrid: Katz Editores, 2007, pp. 292-314.

WATT, Ian. A ascensão do romance. São Paulo: Companhia das Letras, 2010. 
WEFFORT, Francisco. Classes populares e política (contribuição ao estudo do populismo). São Paulo: Faculdade de Filosofia, Ciências e Letras (USP), 1968 (mim). WIGGERSHAUS, Rolf. A Escola de Frankfurt: história, desenvolvimento teórico, significação política. Rio de Janeiro: Difel, 2002.

XAVIER, Ismail. Alegorias do subdesenvolvimento: cinema novo, tropicalismo, cinema marginal. São Paulo: Cosac Naify, 2012.

. Sertão mar: Glauber Rocha e a estética da fome. São Paulo: Cosac Naify, 2007. 